
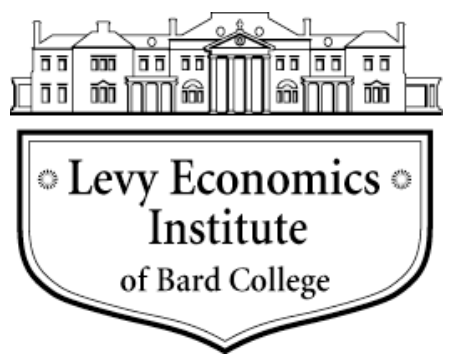

Working Paper No. 845

\title{
The Euro's Savior? Assessing the ECB's Crisis Management Performance and Potential for Crisis Resolution
}

\author{
by \\ Jörg Bibow* \\ Levy Economics Institute of Bard College
}

September 2015

\footnotetext{
* I am grateful for comments on an earlier draft from Sheila Dow, Charles Goodhart, Andrea Terzi, Mario Tonveronachi, Nicolas Véron, and Gennaro Zezza. This paper was supported by the IMK Macroeconomic Policy Institute and published as IMK Study No. 42.
}

The Levy Economics Institute Working Paper Collection presents research in progress by Levy Institute scholars and conference participants. The purpose of the series is to disseminate ideas to and elicit comments from academics and professionals.

Levy Economics Institute of Bard College, founded in 1986, is a nonprofit, nonpartisan, independently funded research organization devoted to public service. Through scholarship and economic research it generates viable, effective public policy responses to important economic problems that profoundly affect the quality of life in the United States and abroad.

Levy Economics Institute

$$
\text { P.O. Box } 5000
$$

Annandale-on-Hudson, NY 12504-5000

http://www.levyinstitute.org

Copyright (C Levy Economics Institute 2015 All rights reserved 


\begin{abstract}
This study assesses the European Central Bank's (ECB) crisis management performance and potential for crisis resolution. The study investigates the institutional and functional constraints that delineate the ECB's scope for policy action under crisis conditions, and how the bank has actually used its leeway since 2007 - or might do so in the future. The study finds that the ECB may well stand out positively when compared to other important euro-area or national authorities involved in managing the euro crisis, but that in general the bank did "too little, too late" to prevent the euro area from slipping into recession and protracted stagnation. The study also finds that expectations regarding the ECB's latest policy initiatives may be excessively optimistic, and that proposals featuring the central bank as the euro's savior through even more radical employment of its balance sheet are misplaced hopes. Ultimately, the euro's travails can only be ended and the euro crisis resolved by shifting the emphasis toward fiscal policy; specifically, by partnering the ECB with a "Euro Treasury" that would serve as a vehicle for the central funding of public investment through the issuance of common Euro Treasury debt securities.
\end{abstract}

Keywords: Monetary Policy; Currency Union; ECB; Lender of Last Resort; Euro Crisis; Banking Union

JEL Classifications: E42, E44, E52, E58, E61 


\section{INTRODUCTION}

This study sets out to assess the European Central Bank's (ECB) crisis management performance and potential for crisis resolution. The ECB has exclusive responsibility for conducting monetary policy in the euro area, with the primary objective of maintaining price stability. On numerous occasions in recent years the ECB played a prominent part in reining in market panic and deescalating fears of an incipient euro exit or breakup. Only recently the ECB has launched a new large-scale asset purchase program, or "quantitative easing" (QE) initiative, featuring the purchase of public sector debt securities, that is aimed at pushing inflation back up toward "below, but close to, 2 percent." Once again financial markets have greeted the ECB's move with relief and euphoria, resulting in a significant easing in financial conditions across the euro area. But doubts remain regarding the efficacy of the measure, whether it will prove to be enough to prevent further slippage into outright deflation and ensure a self-sustaining recovery.

Some commentators therefore see an even bigger role for the ECB in resolving the euro crisis. For instance, Pâris and Wyplosz (2014) propose that the Eurosystem's balance sheet should be used to achieve an area-wide public debt restructuring through the purchase of public debt securities (in much greater volumes than currently foreseen in the ECB's QE initiative) and swapping them for noninterest-bearing perpetuities. Muellbauer (2014) proposes that the ECB should expand its balance sheet by simply sending out a $€ 500$ check to every adult citizen of the euro area, as a monetary stimulus by "helicopter money." Can the ECB really be the euro's savior? Or are we expecting too much from the euro's guardian of stability?

The study investigates the institutional and functional constraints that delineate the ECB's scope for policy action under crisis conditions and how the ECB has actually used its leeway since 2007 or might do so in the future. Giving due regard to the identified constraints, as well as to failures in other policy areas, we find that the ECB has generally done "too little, too late" to rescue the euro area from getting stuck in recession and protracted stagnation and ending up in its current predicament, which features a stark downward miss of its price stability mandate. It appears however that the ECB's latest policy initiative may have finally established financial conditions that would be sufficiently supportive of the recovery of domestic demand if the political authorities agreed to foster recovery directly through a fiscal stimulus. 
The study begins with a brief review of the economic record under the euro in section 2. Section 3 discusses the peculiar vision of central banking that underlies the Maastricht Treaty. It identifies the institutional and functional constraints that delineate the ECB's scope for policy action. Section 4 reviews the ECB's ancillary role in financial stability policy prior to the crises. Section 5 then analyzes in some detail the ECB's crisis management from August 2007 until 2014. The ECB's evolving role in financial stability policy and the "banking union" project are the subject of section 6, while section 7 provides an assessment of the ECB's latest policy initiative and the bank's potential role as the euro's savior. Section 8 concludes and offers policy recommendations.

\section{ECONOMIC RECORD UNDER THE EURO: SLIPPERY JOURNEY FROM UNIMPRESSIVE TO DISMAL}

According to ECB president Mario Draghi, completing the euro monetary union means "having conditions in place that make countries more stable and prosperous than they would be if they were not members. They have to be better off inside than they would be outside" (Draghi 2015a). While the hypothetical alluded to is impossible to prove, Mr. Draghi raises an important question here: Are euro-area member states today really better off thanks to sharing the euro as their common currency? Put differently, has the euro contributed to stability and prosperity in Europe? Implicitly acknowledging that the answer to these questions is not obviously "yes," Mr. Draghi's comparison of two states, Europe with or without the euro, actually refers to what he considers to be a more "complete" monetary union.

In fact, it is a widely held view today that the euro was launched as a somehow "incomplete" monetary union, without observers necessarily agreeing on what the most important aspects of this incompleteness may be. It does however mean that throughout this investigation we will have to bear in mind that Europe's "Economic and Monetary Union" (EMU) is a rather peculiar construct that makes it rather different from, for instance, the United States and, similarly, that the ECB is a rather peculiar central bank operating under unique institutional and functional constraints. 


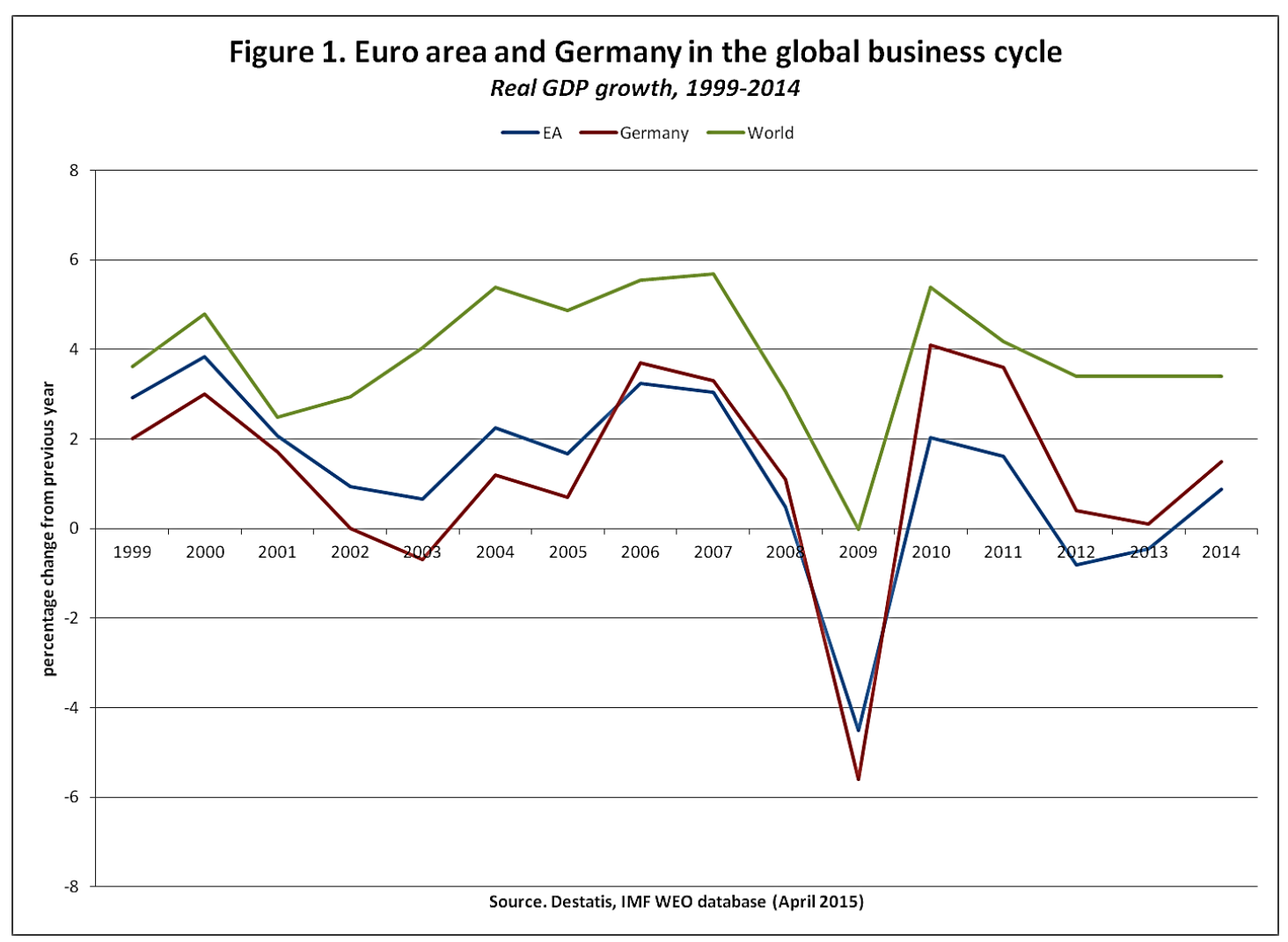

Figure 1 shows the euro area's GDP growth rate since 1999 together with Germany's, as well as global GDP growth. The euro was launched at the late stage of the boom of the 1990s that featured the long "Clinton" or "dot-com" boom in the U.S. By contrast, much of the 1990s were characterized by more subdued growth in the euro area (Padoa-Schioppa 2004), with the prospective euro member countries struggling to meet the critical fiscal threshold level: a maximum budget deficit of 3 percent of GDP by means of austerity policies. The global slowdown of 2001 then also had more of a lasting impact on the euro area than globally. Germany especially lagged behind markedly in the global recovery and became known in this period as the "sick man of the euro." The euro area, and even more pronounced in the case of Germany, only joined the record global boom of the 2000s at a very late stage - and hence for two years only.

While the euro area's boom was brief and unimpressive, the collapse in GDP growth in the global crisis of 2008-09 again proved more pronounced for the euro area and Germany than was the case globally. As to the post-crisis recovery, the picture is truly dismal. The euro area and 
Germany bounced back temporarily in 2010, but quickly fell back into recession in 2011 . Domestic demand contracted for two years while net exports have made sizeable positive growth contributions since 2010 with the emergence of the euro area's soaring current account surplus position. Meanwhile, fortunes have changed between Germany and the euro area as the former laggard has turned into the currency union's supposed "powerhouse." Overall, the euro area and Germany seem to participate fully in global slowdowns and recessions, but have far more trouble recovering from them —as remains true until today.

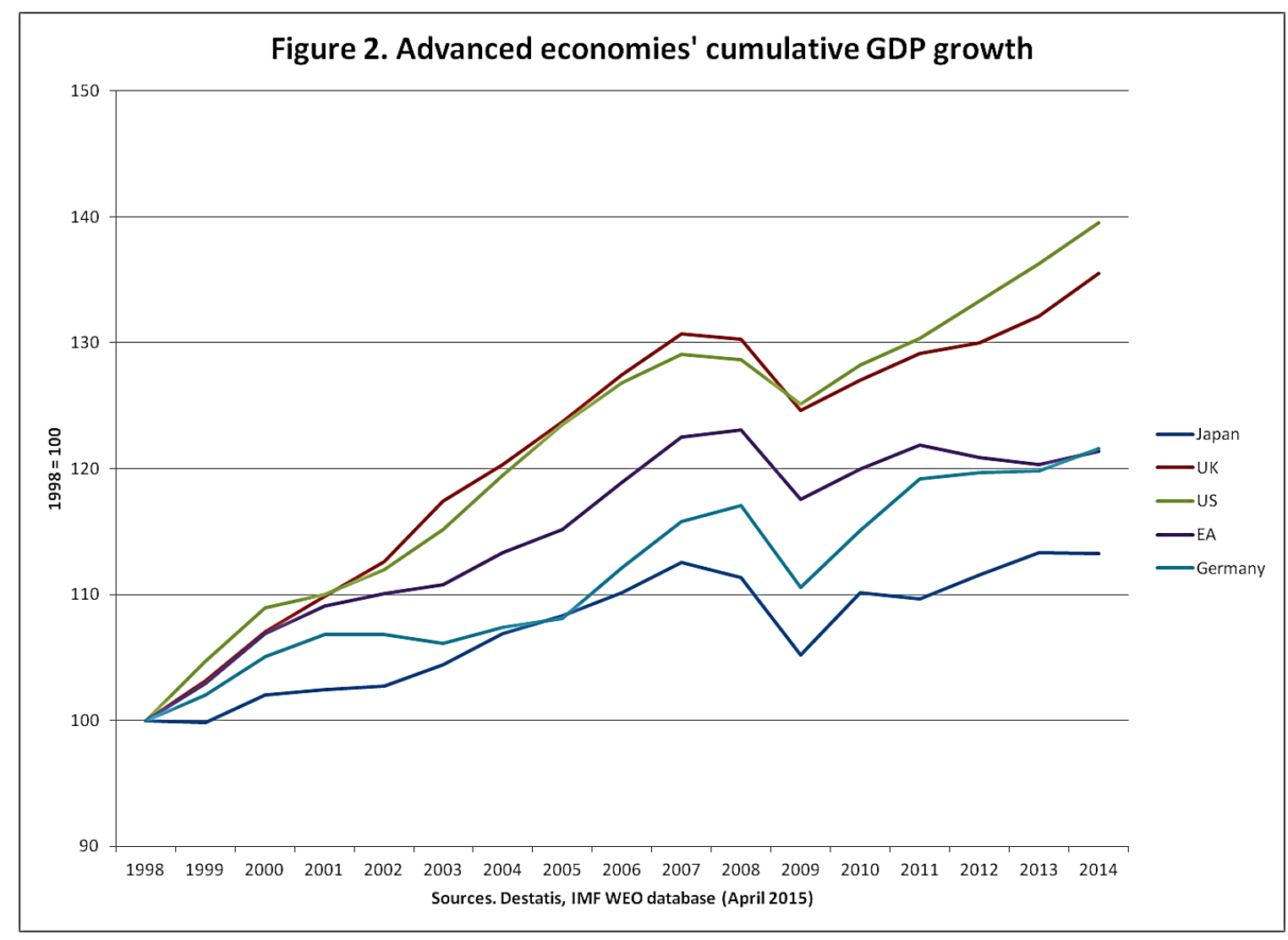

Looking at cumulative GDP growth since 1999, figure 2 highlights that the euro area's performance since the global crisis has been even poorer than Japan's. There is much discussion in the U.S. and U.K. today about the disappointing recovery of their economies from the global crisis. But the euro area has yet to even reclaim its pre-crisis level of GDP, while domestic demand was still nearly 5 percent below its pre-crisis peak level in late 2014. The euro's sick 
man Germany was close in performance to Japan prior to the crisis. Germany is slightly ahead of its pre-crisis peak level today, having just about caught up with the euro area as a whole overall in 2014. While unemployment has declined significantly in Germany over the past ten years, unemployment remains stuck at record high levels for the euro area as a whole.

In short, the euro area's economic record went from unimpressive prior to the crisis to dismal post crisis (Darvas, Pisani-Ferry, and Wolff 2013; De Grauwe 2015). If the euro was meant to be an engine of joint European prosperity and solidarity, the euro experiment has failed quite miserably. On any reasonable account the euro project has proved a first-class policy fiasco. ${ }^{1}$ If anything, actual outcomes were the opposite of the goals stated in Article 2 of the Amsterdam Treaty of 1999: "a harmonious, balanced and sustainable development of economic activities." What part did the ECB and the Eurosystem ${ }^{2}$ play in this outcome? Two mainstream ideas might at first seem to suggest a clean sheet for the ECB: the money neutrality postulate and optimum currency area theory.

Starting from the money neutrality postulate, mainstream economists may be tempted to quickly absolve the ECB from any responsibility with regard to poor performance of the real economy. Superficially the money neutrality postulate suggests that only nonmonetary forces must have been at play in keeping the euro area under duress for such an extended period of time, seemingly also justifying notorious calls for "structural reforms." It is however important to appreciate that money neutrality presumes that any errors in central bank policy are randomly distributed and cancel out over time. Even from the perspective of the quantity theory of money systematically erring in one direction, persistently setting an insufficiently accommodative monetary stance can have lasting detrimental real effects, and any finding of a policy bias (or

\footnotetext{
${ }^{1}$ One may recall here the triumphant euro anniversary proclamations of 2008: "A full decade after Europe's leaders took the decision to launch the euro, we have good reason to be proud of our single currency. The Economic and Monetary Union [EMU] and the euro are a major success. For its member countries, EMU has anchored macroeconomic stability, and increased cross-border trade, financial integration and investment. For the EU as a whole, the euro is a keystone of further economic integration and a potent symbol of our growing political unity. And for the world, the euro is a major new pillar in the international monetary system and a pole of stability for the global economy. As the euro area enlarges in the coming years, its benefits will increasingly spread to the new EU members that joined in 2004 and 2007" (Almunia 2008). See also Trichet (2008).

${ }^{2}$ The EU treaties established the European Central Bank (ECB) and the European System of Central Banks (ESCB), where the latter includes the ECB and the national central banks (NCBs) of all (28) EU member states. Since not all EU member states have joined the monetary union (the "Eurosystem") including the ECB and only the NCBs of the (19) EU member states that have adopted the euro, became the entity actually in charge of monetary policy (and central banking functions more broadly) in the euro area. In this study I will mostly refer to the ECB as representative of monetary and crisis management policy in the euro area and only distinguish between the Eurosystem and its constituent parts when this is a relevant issue for the analysis at hand.
} 
bias for policy inaction in case of deflationary risks) would imply costly policy failures on the part of the ECB. ${ }^{3}$ The euro area's track record of failure to recover more promptly from a growth slowdown, recession, or crisis is noteworthy here.

But the euro area's inflation record, too, may actually be indicative of a policy failure of this kind. Two types of target misses have been experienced under the euro: first, persistent target misses in the upward direction prior to the crisis and, second, a crass target undershooting in more recent times. The point is that both types of target misses may actually owe to the same kind of policy error: asymmetric monetary policy conduct, policy afflicted by an anti-growth bias.

The possibility that the ECB may have been insufficiently accommodative during the period under review here is increasingly becoming conventional wisdom today. It is undeniable that the ECB, apart from prematurely hiking rates in 2011, did not resort to the more aggressively expansionary nonstandard policy measures used by other key central banks, such as the Federal Reserve, Bank of England, or Bank of Japan. In light of these stark differences in policy stance one would need to assert that monetary policy is completely ineffective rather than just "neutral" in the classical sense. ${ }^{4}$ Both headline and underlying inflation have been on a plainly declining trend since late 2011. Since the implementation of its unconventional emergency measures in late 2011 and early 2012 (to be discussed in detail further below), the ECB has remained largely passive, watching the euro area slipping into outright deflation by late 2014 . We will have to investigate why the ECB has not been more forthcoming with its support. It

\footnotetext{
${ }^{3}$ It is telling that none other than Milton Friedman rebutted Otmar Issing, the ECB's influential first chief economist, for suggesting that standard monetary neutrality propositions would be among the few results a prudent central banker can get comfort from. Quoting Keynes, Friedman $(2002,367)$ countered: "Taken seriously, monetary neutrality means that central bankers are irrelevant: real magnitudes-which are what ultimately matter to people - go their own way, independently of what the central banker does. Central bankers are important insofar as money is not neutral and does have real effects. Neutrality propositions give little if any guide to effective central bank behavior under such circumstances. Perhaps they offer comfort to central bankers by implying that all mistakes will average out in that mythical long run in which Keynes assured us 'we are all dead.' Keynes [Tract on Monetary Reform (1923)] went on, 'Economists [central bankers] set themselves too easy, too useless a task if in tempestuous seasons they can only tell us that when the storm is long past the ocean is flat again." While Friedman believed in the money neutrality postulate at the level of theory, he understood all too well that monetary policy may not be neutral in practice, blaming Federal Reserve policy blunders for the depth of the Great Depression. See Friedman and Schwartz (1961).

${ }^{4}$ The empirical evidence suggests effectiveness however. See, for instance, Gagnon et al. (2011), Bowdler and Radia (2012), Goodhart and Ashworth (2012), Joice at al. (2012), Butt et al. (2014), Peersman (2014), Rogers, Scott, and Wright (2014), and Weale and Wieladek (2014). See also Woodford (2012).
} 
would appear to be the mainstream view today that it was a mistake on the part of the ECB to abstain from the use of more accommodative policies in a more timely fashion.

It may seem counterintuitive to suggest that the persistent target misses in the upward direction in the pre-crisis period are also owed to a lack of — rather than excessive - monetary accommodation. The issue here is also related to the stylized fact of conspicuously slow postslump recoveries (and accordingly brief booms). The point is that protracted stagnation creates budgetary pressures. Operating under the constraints of the so-called Stability and Growth Pact (SGP), stagnation-induced budgetary stresses gave rise to frequent hikes in indirect taxes and administered prices in numerous member states. This happened both following the global slowdown in the early 2000s and again when the fiscal rudder was shifted toward unconditional austerity starting in the course of 2010. In each case fiscal austerity was giving rise to very sizeable and persistent upward distortions in headline Harmonized Index of Consumer Prices (HICP) inflation.

This may be clearly seen in figure 3, which, in addition to headline HICP inflation, shows two measures of core inflation. The first is a standard core measure excluding energy, food, tobacco, and alcohol products. The second additionally excludes an estimate of "tax-push" inflation (or: upward price distortions caused by hikes in indirect taxes and administered prices). In the mid2000s the tax-push contribution to headline inflation was around $0.5-0.7$ percentage points for a number of years. ${ }^{5}$ The ECB traditionally focuses on headline inflation, which seemed "elevated" (above target) all along. Yet, by providing relief to budgetary pressures, more accommodative monetary policy may actually lead to lower inflation. It is unwise to ignore the interaction between monetary and fiscal policies, especially under the Maastricht regime, which seems to single-mindedly focus the authorities involved on one magical number, 2 percent and 3 percent, respectively. As a result, both authorities failed to hit their target during the protracted stagnation of the mid-2000s (Bibow 2006a; see also Hein and Truger 2007).

When the global crisis struck, governments initially abstained from any measures that would have caused tax-push inflation, but starting in 2010, when unconditional austerity kicked in continent-wide, tax-push inflation surged to reach a 1 percentage point contribution to headline

\footnotetext{
${ }^{5}$ An important contributor to tax-push in 2007 was a 3 percentage-point VAT hike in Germany. This hike was implemented with a delay. Its motivation clearly owed to Germany's misses of the 3 percent SGP norm for four years in a row in the mid-2000s.
} 
inflation at its peak. Figure 3 shows that underlying inflationary pressures owing to market forces have stayed extraordinarily low, below 1 percent, ever since 2010. Since late 2012 taxpush inflation has gradually declined again, and so have both headline and the standard core inflation measures, while the core inflation measure that excludes tax-push inflation has stayed at or below 0.5 percent ever since. Towards the end of 2014, headline inflation entered into negative territory. While the latest decline in headline inflation was significantly affected by the oil-price slump in 2014, it is quite clear that pronounced disinflationary forces have been at play for quite some time. For any central bank with an inflation target of 2 percent, alarm bells would have gone off in the spring of 2013 at the very latest. Why has the ECB stayed put for so long?

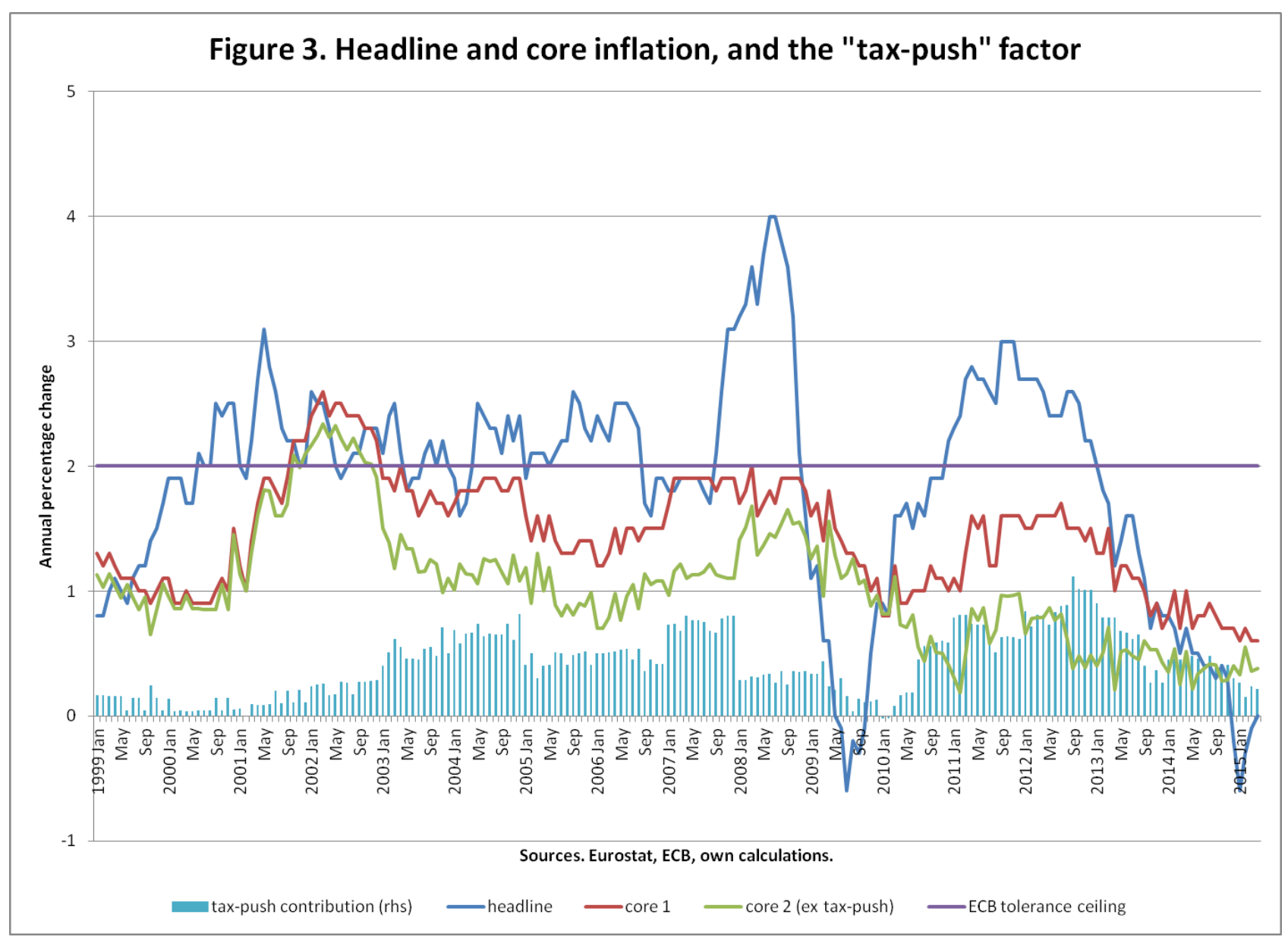


The idea that monetary policy may have been insufficiently accommodative overall also seems to conflict with the evidence of asset price bubbles together with rapid domestic demand growth, if not overheating, in some member states. It is important not to confuse the question whether or not monetary stance was appropriate for the currency union as a whole with the altogether different matter of whether or not monetary policy requirements may have been sufficiently aligned across member states.

Since the crisis, the aspired "singleness" of monetary policy has become an important issue indeed. Singleness of monetary policy means that the monetary policy stance, as made effective in the market by way of the central bank's short-term policy interest rate target, translates into broadly uniform financial conditions across the currency union. Prior to the eruption of the crisis this had increasingly been the case over time; so much so that the "interest rate convergence" process observed since the mid to late 1990s, and which continued under the euro (specifically of government bonds yields), is nowadays seen by some observers as the chief cause of the real divergences that happened under the euro. While certainly relevant, this argument is at risk of ignoring that other forces, too, were at play that were seriously unbalancing intra-area competitiveness positions, causing diverging domestic demand growth trajectories, surging current account imbalances, and, accordingly, explosive internal and external indebtedness trends in some member countries.

Prior to the crisis real divergences and hence the divergence in monetary policy requirements rather than any missing singleness in monetary policy per se was the challenge of the day. And, in a sense, those real divergences were not really a challenge for monetary policy either because, according to optimal currency area theory, there is nothing that the central bank can do about them anyway. The common central bank is condemned to set one common rate of interest which must fit all—or not. The central bank is seen as being powerless in countering the impact of asymmetric shocks or dealing with problems that have their roots, whether real or apparent, in structural heterogeneities and rigidities. At best, the single monetary policy can only be made to fit the currency union as a whole.

Of course this not only begs the question whether the euro area was actually hit by any proper asymmetric shock-causing consequences that were unavoidable or at least could not have been countered by the single monetary policy. It also still leaves the question whether the ECB had 
played a constructive part in preparing the currency union under its guardianship for the potential occurrence of such shocks, both regarding the timely detection of vulnerabilities in the financial system as well as by nourishing its robustness, in particular.

Since the onset of the crises intra-area divergences have got even worse, although the parties have switched sides as former growth stars turned into crisis economies, while Germany moved up from "sick man" to supposed "growth engine." So the ECB has increasingly faced the double challenge of operating in an environment of stark real divergences and a lack of singleness of its monetary policy.

These remarks are only meant to prepare the ground for this inquiry: an assessment of the ECB as crisis manager. They are not intended to rush to judgment regarding the ECB's part in the euro area's dismal economic record. From early on, the crisis experience since August 2007 required the ECB to amend its operational procedures of monetary policy implementation in creative ways. In due course the bank was also required to interpret its mandate and wider role in sustaining the currency union more flexibly and broadly, including in ways that provoked legal challenges apart from shedding some interesting light on central banking functions and the peculiarities of Europe's currency union.

For "the" crisis that has been ravaging the euro area since 2007 (and still remains unresolved until today) has evolved over time, experiencing a number of reincarnations. It all started as a banking crisis. European banks suffered huge losses on their U.S. exposures right from the start of the "U.S. subprime mortgage crisis." It was around that time, too, that local bubbles in the euro area started to unravel, threatening further colossal banking losses. Financial market turmoil and banking failures (and rescues) then triggered two further related crises. Most publicity was awarded to the "sovereign debt crisis," which was merely the consequence of banking losses and slumping economies, but not the deeper cause of the euro area's troubles at all. The crisis has certainly highlighted how closely intertwined the fate of sovereigns and their national banking systems are inside the peculiar euro currency union.

But by far the most serious threat to the euro has been the quasi-balance of payments crisis that struck when cross-border interbank lending froze and capital flows reversed. A widespread illusion had held out that balance of payments crises would not be an issue inside the euro currency union. It was ignored during the run-up to the crisis that diverging competitiveness 
positions resulted in surging external indebtedness on the part of current account deficit countries, creating serious fragilities and vulnerabilities. It was also ignored that the euro area had no defenses in place to protect the currency union in case the mounting intra-area imbalances unraveled - as they surely were to at some point (Bibow 2005, 2006b, 2007a, b).

The manifold challenges arising from the unfolding and metastasizing triple crisis would have been bad enough, but the situation was made much worse when policies were put in place in a response that lastingly suffocated domestic demand. Mindless austerity policies provoked a growth crisis on top of the triple-crisis challenges, pushing the euro area towards the abyss of a full-blown debt deflation at which the euro area currently sleepwalks as political crises fester. How much does this situation owe to the "incompleteness" of the currency union? How much blame can be placed at the ECB's own doorsteps?

The next section discusses the vision of central banking that inspired the Maastricht Treaty. The aim is to identify potential conflicts between the institutional and functional design of the ECB on the one hand, and the realities of central banking in an incomplete currency union on the other.

\section{CENTRAL BANKING AND THE MAASTRICHT TREATY}

Historically, central banks have evolved fulfilling various functions in three broad policy areas related to the currency sphere and the financial system: public finances, financial stability, and monetary policy. These three traditional central banking domains are partly overlapping and the various central banking functions inherently intertwined. For instance, a central bank with a monetary policy mandate to maintain price stability can hardly stay aloof of the financial stability domain completely, given that serious financial system dysfunction may come to pose an acute deflation threat and hence undermine the pursuit of its primary monetary policy mandate. Also, a financial crisis can have grave fiscal consequences which, in turn, may condition the monetary policy stance in important ways. In fact, monetary policy and debt management may have to work hand in hand to contain the debt service burden and maintain 
fiscal space. Failure to do so may prompt counterproductive fiscal austerity, which might ultimately end in deflation, too.

In any case, a currency that is not convertible into anything else is inevitably a significant factor in the public finances of the state issuing it (Hellwig 2014a), even if certain policy functions related to the currency may be assigned to an "independent" central bank agent. Central banks typically issue their liabilities by making (collateralized) loans or buying (low-risk) debt securities. As their assets typically yield positive returns while their liabilities either pay no or below-market interest rates, they are bound to earn monetary income (or: seigniorage). Seigniorage tends to rise or fall in line with the size of the central bank's balance sheet and the magnitude of the interest-rate spread on its assets over its liabilities. Central banks do not normally compete with banks - their own customers - for business though. The spreads they set as "dealers in money and debts" (Keynes 1936), and the wider effects their policy rates have on financial conditions and the economy, strongly affect their customers' balance sheet health and profitability. As central banks are typically owned by the state, it is useful for some purposes to treat the central bank and treasury department as one integrated balance sheet controlling public finances and money issuance. Keeping the two balance sheets separate serves to highlight the specialized banking functions undertaken by central banks on behalf of the state.

In fact, an early generation of central banks (to-be) was actually founded with the explicit aim of supporting public finances, through either direct lending to the government and/or underwriting public debt issuance, and as a depository of public funds, in particular. The Bank of England (1694), Banque de France (1800), First Bank of the United States (1791), and Banco Nacional de San Carlos [(1782), forerunner of the Banco de Espana (1856)], but also the Prussian Bank (1846) and earlier the Royal Giro and Loan Bank (1765), forerunners of the German Reichsbank (1876), provide examples of early central banks (to-be) primarily acting as "government bank" in the public finance domain. These banks' privileged position within the banking and monetary system as government bank laid the basis for their emerging dominant position vis-à-vis other banks, which in due course meant withdrawal from market competition together with the acceptance of the "lender of last resort" (LOLR) role; that is, the provision of emergency liquidity assistance to specific institutions and/or money markets in general under conditions of market stress and with the aim of forestalling a financial system meltdown; see Bagehot ([1873] 1999), Goodhart (1988), and Capie, Goodhart, and Schnadt (1994). 
As financial stability concerns more and more claimed center stage over time, a later generation of central banks - the U.S. Federal Reserve System (1914) being the most important example here - was founded with the primary aim of safeguarding financial stability through providing an "elastic currency." This central banking duty typically came in conjunction with also assuming some more or less comprehensive banking oversight responsibilities, including oversight over the potential recipients of emergency liquidity assistance. Adding financial stability policy to central banks' portfolio of duties typically did not mean passing up on their older role as government bank. For instance, the Federal Reserve continued to provide banking services to the government and remained under a commitment of maintaining orderly government debt markets. Suffice to mention that centralization of currency issuance and in some cases currency unification (the German Reichsbank, for instance) or currency restoration (the Austrian Nationalbank, for instance) provided another related motivation in the evolution of central banking, also highlighting central banks' natural position at the center of the national payments system; see Goodhart (1988) and Capie, Goodhart, and Schnadt (1994).

From a historical perspective, the Deutsche Bundesbank was established in 1957 as a rather untypical central bank, with functions primarily concentrated in the monetary policy domain, which at the time featured a fixed exchange rate regime, though initially in an environment of limited capital mobility (Holtfrerich 1999). The Bundesbank was peculiar in a number of ways actually. To begin with, authority for banking regulation and supervision was granted to a separate government institution, the Bundesaufsichtsamt für das Kreditwesen. The Bundesbank only played a junior role in the practical execution of bank supervision, and without any provisions specifically covering its potential role as LOLR (Prati and Schinasi 2000).

Furthermore, while the Bundesbank did also act as fiscal agent, providing debt management and depository services to the government, its authority to lend to the government by way of liquidity bridging loans ("Kassenkredite") was tightly limited in volume (though not zero!). Both of these peculiar features were related to the Bundesbank's acclaimed status as an "independent" central bank within the new West German state and government, arguably the most important peculiarity at the time, which was the outcome of an almost decade-long 
struggle between the central bankers at the Bank deutscher Länder (BdL, established in 1948) and the West German political authorities. ${ }^{6}$

Initially, it came as an unwelcome surprise to central bankers that the government established another separate federal authority in charge of banking supervision in 1957, the same year in which the Bundesbank Law finally passed. Related to the long fight over its independence, the intention was to thereby limit the powers of the newly established Bundesbank. The tight restrictions placed on direct loans to the government owed to earlier historical experiences. During the First World War the Deutsche Reichsbank was made an instrument of war finance. Burdened by the consequences of the war and reparations imposed on Germany by the victor countries, the Weimar Republic proved politically unstable and the Reichsbank obedient in expanding its lending to fill the persistent gap in the government's budget. Rudolf Havenstein, the Reichsbank's president from 1908 until 1923, thought that the central bank's most serious challenge at the time was to print banknotes sufficiently fast enough so as to keep step with the rising demand for them, attributing inflation to foreign speculators and currency depreciation. The infamous Weimar hyperinflation was followed by currency reform ("Rentenmark") and left the Reichsbank with foreign representatives on its controlling General Council. The Reichsbank subsequently oversaw the banking crisis of 1931 and the Brüning austerity policy and deflation that followed the sudden stop in capital flows triggered by the Wall Street crash of 1929 (James 1998).

Walter Eucken, the figurehead of Germany's peculiar ordoliberal tradition in economics (see Rieter and Schmolz 1993, Starbatty 1994, Grossekettler 2003), offered a scathing critique of the Reichsbank's role in the Weimar hyperinflation (Eucken 1923). But Eucken was also highly critical of the autocratic conduct of the Reichsbank in the subsequent period, ushering into the Weimar deflation and Nazi takeover. An unpublished" report, "On the nationalisation of the central bank," of 1946 is of particular interest in this regard. In that report Eucken laid out his

\footnotetext{
${ }^{6}$ The argument that the Allies may have imposed central bank independence on West Germany (Buchheim 1998, 2001) is actually missing the point. It would have been odd for them to do so, given that their own central banks back home did not enjoy much of an independent status at the time. The BdL was initially controlled by the "Allied Banking Commission," as no federal German government even existed at the time. When the Allies later withdrew their control they actually demanded that the new West German government established their own form of control over the central bank (Bibow 2009a, 2010); see also Hentschel (1988), Holtfrerich (1988), Stern (1998), and Distel (2003).

${ }^{7}$ I am indebted to Walter Oswald (Walter Eucken Archiv, Frankfurt am Main) for making this report available to me and granting me permission to quote from it.
} 
ideas on how the central bank might be best integrated into the system of state control, comparing two opposing solutions. The German Bank Law of 1924 provided one extreme of an independent central bank. Eucken acknowledges the advantage of blocking central bank financing of budget deficits, but rejects the model overall on the following general grounds: "an all too independent and weakly controlled central bank is difficult to fit into the structure of the state. It will be tempted to position itself in opposition to the general economic policy of the state. A 'pluralism' will easily develop that would jeopardize the unity of state policy" (Eucken 1946; my translation). An example for the other extreme was provided by the German Bank Law of 1939 that fully integrated the central bank into the state apparatus. In his view, this would invite inflationary risks due to free access to central bank credit. Eucken thus favored an interim solution, featuring a balance of power between the Treasury and central bank. While retaining the central bank as an autonomous institution with monopolistic privileges, the central bank was to receive its statutes from the state and be subjected to "precisely specified state control, which would make it impossible for it to conduct its own economic policy against the state" (Eucken 1946; my translation).

Of course the Reichsbank had once again become an instrument of war mobilization and war finance under Hitler. Only the monetary reform of June 20, 1948 ("Deutsche Mark") brought a return of monetary order to the still allied-controlled western German occupation zones (Möller 1976). In preparation of the currency reform, the Bank deutscher Länder was established earlier in the same year as the cockpit of the decentralized central bank system of the new West Germany (to be). It is of some interest that in the early post-war period controversy in West Germany about the status of its central bank still featured arguments opposing independence highlighting the Reichsbank's deflationary blunders during the Great Depression, especially from German industry — concerns which seem to have been erased from collective memory meanwhile (Bibow 2010).

Be that as it may, as its mandate (or: "functions"), the Bundesbank Law of 1957 laid down that West Germany's new central bank "regulates the amount of money in circulation and of credit supplied to the economy, using the monetary powers conferred on it by this Act, with the aim of safeguarding the currency, and sees to the execution of domestic and external payments" (Bundesbank Law, Article 3). Furthermore, the Bundesbank Law laid down that "without prejudice to the performance of its functions, the Deutsche Bundesbank is required to support 
the general economic policy of the Federal Cabinet" (Article 12). While independent of instructions from the Federal Cabinet, the law did ask that the two sides cooperate in certain ways (Article 13), while the federal government also retained ultimate authority in the area of exchange rate policy, specifically Ludwig Erhard's economics ministry. ${ }^{8}$

In practice, the accumulation of foreign exchange reserves (gold and U.S. dollars) was the foremost factor in the creation of central bank money under the Bretton Woods regime (actually until the 1980s), when the Bundesbank also lent to the banking system through traditional discount and open market operations (since the mid-1980s increasingly in the form of repo operations). On occasion, the Bundesbank also conducted outright purchases (and sales) of long-term government debt securities in secondary markets. This first occurred in the recession of 1967 arising in the context the new "Stability and Growth Act" (Stabilitäts- und Wachstumsgesetz) of that year. The act marked the beginning of the belated and brief Keynesian era in German macro policymaking. The rather obvious aim of those outright purchases was to more directly steer longer-term interest rates downwards. Yet, as the Bundesbank Law laid down that open market operations, including in public debt securities, were to be undertaken "in order to regulate the money market" (Article 21), the Bundesbank was always keen to emphasize that long-term interest rates were determined predominantly by market forces. Moreover, while also undertaking open market operations in long-term public debt instruments on occasions in the 1970s and 80s, the Bundesbank abstained from building up any sizeable portfolio of long-term public debt over time as "this might easily give rise to the suspicion that [the central bank's] primary aim was to facilitate the financing of public sector budget deficits, even if that motive were not in fact of any significance at all" (Bundesbank 1994, 88).

Apparently the Bundesbank was not too keen to explain to the public that outright purchases of long-term government debt securities may serve purely monetary policy purposes. Rather, the Bundesbank's foremost conviction was that the Bundesbank must not be perceived as facilitating the financing of budget deficits. (West) Germany's post-war history until the 1990s

\footnotetext{
${ }^{8}$ Ludwig Erhard is widely regarded as the "father of West Germany's economic miracle." In this regard, he is thought to have established ordoliberal principles in economic policymaking in West Germany. He is also known as a strong supporter of central bank independence; yet he did not shy away from his right to attend governing council meetings and argue with the independent Bundesbankers. On one such occasion $\left(96^{\text {th }}\right.$ Central Bank Council Meeting on May 30, 1961) he exclaimed: "independence of the Bundesbank presupposes that a common line will be found" (Minutes p. 13, Bundesbank Archive HA B 330/178; my translation; cf. Berger [1997: 201]). Erhard's resignation as West Germany's second chancellor in 1966 has been attributed to the Bundesbank (Marsh 1993).
} 
featured a number of recessions and periods of very low inflation. ${ }^{9}$ (West) Germany suffered a balance-of-payments crisis early on (1953), while later episodes of currency market stresses typically were owed to pressures for deutschmark appreciation (Hölscher 1994). There was only one bank failure of any global significance (Herstatt). Overall, (West) Germany's post-war monetary history features nothing even remotely comparable to the events in the euro area in recent years. In particular, owing to the fairly strong position of unions in (West) Germany's "social market economy" there was never any acute risk of falling wages. It was therefore always safe and wise for the Bundesbank to just wait quietly for exports to revive and kick start the economy. The Bundesbank experimented with capital controls to counter capital inflows and deutschmark appreciation, but it never experienced any vital need for Keynesian experimentation with unconventional monetary policies to overcome severe recession and counter any threat of deflation.

Keynes first explored the idea of more direct central bank control over longer-term rates of interest in his Treatise on Money. Already in his earlier Tract on Monetary Reform had he discussed the distinction between central bank money being provided at the central bank's initiative through outright open market purchases and the passive provision of liquidity at the banks' discretion through advances at the policy rate. Outright purchases may not impact money market conditions if banks reduce their recourse to advances or pay back loans. In the Treatise he focuses on the benefit of directly steering longer-term rates which, he believes, may have a greater influence on investment decisions. Money market rates may be constrained by international considerations or be zero already. He refers to "extraordinary methods" to be applied in "acute circumstances." As a "remedy in the event of the obstinate persistence of a slump" he proposes that the central bank should carry out open market operations in long-term securities à outrance. The central bank may not actually end up purchasing bonds of such excessive amounts though as long as it is able to draw the banks in the desired direction:

If the central bank supplies the member banks with more funds than they can lend at short term, in the first place the short-term rate of interest will decline towards zero, and in the second place the member banks will soon begin, if only to maintain their profits, to second the efforts of the central bank by themselves buying securities. This means that the price of bonds will rise unless there are many persons to be found who, as they see the prices of long-term bonds rising, prefer to sell them and hold the proceeds liquid at a very low rate of interest. (Keynes 1930, JMK 6, 333)

\footnotetext{
${ }^{9}$ Inflation only briefly turned negative in West Germany twice, in 1958 and, due to the fall in oil prices, in 1986.
} 
Note that in this case the central bank and the banks are jointly driving down longer-term interest rates through their bond purchases while the nonbank public ends up holding greater amounts of liquidity (bank deposits); the actual increase in the banks' central bank deposits may be quite limited (namely if the banks rather than the central bank do most of the buying).

The situation is totally different when the banks refuse to follow suit and decline to expand their own bond purchases. It such "extreme situations" it may be the duty of the central bank to go it alone. It may not be possible to drive longer-term rates down sufficiently "unless we impose on the central bank the duty of purchasing bonds up to a price far beyond what it considers to be the long-period norm" (Keynes 1930, JMK 6, 334).

Keynes does not discuss here in any depth why the banks may refuse to buy but prefer ending up with rising liquidity instead; however, his reference to a "long-period norm" implies that the banks may fear future financial losses arising from a normalization of interest rates. After all, monetary policy success implies a recovery from the slump and a normalization of interest rates in due course. The fear of future financial loss is a legitimate reason keeping any individual private bank disengaged. By contrast, public policy must not shy away from aggressive measures when needed, even if they might involve future financial loss of the above kind. Presumably the benefits from an improved state of public finances owing to economic recovery will far exceed any financial loss on the part of the central bank anyway. Note also: as the central bank may feel inhibited from voluntarily risking future financial loss, Keynes hints that the political authorities may need to "impose" their own will upon their monetary agent.

Keynes returned to this issue in The General Theory. He now understands that what he called the "long-period norm" in the Treatise is shaped by market conventions and subject to the expectations management of the central bank. Outright purchases by the central bank are most effective if they not only drive down longer-term rates but also move the market's interest rate convention in the same direction. In general, the central bank and the banks would then expand their balance sheets in parallel. A "liquidity trap" describes a situation where the central bank fails to manage market expectations and shift the market interest rate convention appropriately. In this case the central bank ends up doing the job alone at some point, expanding its own balance sheet through asset purchases while the banks, in fear of future losses, stay passive and watch their liquidity (“excess reserves”) rise (Bibow 2009b). Fear of future losses may arise 
from an anticipated success of the policy initiative, as in the Treatise, but defensive behavior on the part of the banks is also conceivable in case of anticipated policy failure. Bank balance sheet problems or a lack of profitable lending or investing opportunities are further possibilities, if we think beyond outright purchases of government debts.

Keynes took the issue up another notch in The General Theory where he suggests that "perhaps a complex offer by the central bank to buy and sell at stated prices gilt-edged bonds of all maturities, in place of the single bank rate for short-term bills, is the most important practical improvement which can be made in the technique of monetary management" (Keynes 1936, $J M K ~ 7,206) .{ }^{10}$ His later war-time writings on the post-war outlook for monetary management followed this line of ideas and, in view of the anticipated huge public debt overhang as a result of the war effort, recommended close coordination of monetary management and debt management on the part of the Treasury. ${ }^{11}$ Literally setting the whole term (and risk) structure(s) of interest rates by way of quoting bid-ask spreads for all maturities (and risks) represents an extreme case that leaves little scope for market forces in determining interest rates.

A central bank may not need to go quite as far as actually setting the whole term (and risk) structure(s) of interest rates, but instead apply both expectations management and the management of its own balance sheet to the extent needed to move market interest rates towards levels that are deemed appropriate given the current economic situation. The fear of future financial losses may deter private actors from moving along with the central bank beyond a certain point, but that should not deter the central bank itself, which has to "do what it takes," if it is in its power, to fulfill its mandate. It would be quite "natural" for the central bank to purchase a significant amount of the outstanding stock of government debt securities in the secondary market if monetary policy requirements are accordingly; "natural" because government debts are generally considered safe and central banks generally inclined to buy low-

\footnotetext{
${ }^{10}$ This suggestion follows his discussion of liquidity preference and interest rate determination. A more complete statement reads: "If the monetary authority were prepared to deal both ways on specified terms in debts of all maturities, and even more so if it were prepared to deal in debts of varying degrees of risk, the relationship between the complex of rates of interest and the quantity of money would be direct" (Keynes 1936, JMK 7, 205). See also Bibow (2009b).

${ }^{11}$ See Geoff Tily (2007) on Keynes's post-General Theory elaborations on monetary policy and debt management. See also Goodhart (2012). The "Modern Monetary Theory" school (see Wray 2012), which is also inspired by Abba Learner's "functional finance" and Minsky's "financial instability hypothesis" interpretations of Keynes, follows this line of thought and would essentially (permanently) set interest rates at very low levels and rely on other policy instruments to control the financial system and manage aggregate demand.
} 
risk (credit risk free) instruments. Interest rate determination in the secondary market obviously influences conditions in the primary market, the interest rate on (the flow of) new issuances. It reflects flawed thinking to interpret this monetary policy outcome as the central bank "financing the budget deficit." It is regrettable that the Bundesbank has failed to educate the German public in this regard. Perhaps it was too convenient to uphold certain beliefs that can serve exerting discipline on public finances.

The independent Bundesbank, which is fully owned by the federal government, has traditionally enjoyed considerable freedom not only in deciding its own operating expenses, but also in assessing its residual income to be transferred to the federal government. The Bundesbank holds and controls Germany's foreign exchange reserves (including gold), ${ }^{12}$ but the Bundesbank has never encountered any "extreme situations" like the ones referred to by Keynes in his investigations into the possibilities of experimental monetary policy when it was still in charge of monetary policy for Germany (and beyond).

The ECB has ended up being less fortunate. The evolving euro crisis has forced the ECB into experimental modes of policy conduct. The adamant and at times obstructionist resistance it has met from the Bundesbank, itself wholly inexperienced in these matters, and an ill-educated German public and body politic has not been helpful.

The situation is all the more curious since, in many ways, the Bundesbank provided the blueprint for the ECB (Dyson and Featherstone 1999; Padoa-Schioppa 2004; Bibow 2005, 2013a; James 2012). In truth, however, the ECB is even far stranger a central bank animal than the Bundesbank ever was. Awareness of the richness and diversity existing regarding the range of activities that central banks are engaged in, both historically and today, is important to

\footnotetext{
${ }^{12}$ While the Bundesbank never shied away from public conflicts with the German government, and the opportunities such open conflicts presented to the independent central bank in fostering its own reputation, the final episode of such conflict before the launching of the euro was a special curiosity. In 1997, Theo Waigel, finance minister in the government of Helmut Kohl (which also included Wolfgang Schäuble, Germany's current finance minister), famously attempted to "lift the Bundesbank's gold treasure" as Germany was struggling to meet the Maastricht deficit criterion, asking the central bank to revalue its gold holdings and transfer the resulting (unrealized) profits to the government. The government even threatened to amend the Bundesbank law accordingly to force the Bundesbank's hand. Finance minister Theo Waigel was aided in his endeavor by state secretary Jürgen Stark, the later ECB Executive Board member. The Bundesbank successfully resisted and, as on numerous other occasions, the conflict between the bank and the government had mainly one effect: tarnishing the government's prestige while raising that of the Bundesbank.
} 
appreciate the truly peculiar nature and position of the ECB as a modern central bank established in June 1998 as the euro's guardian of stability.

One peculiarity concerns the ECB's role in financial stability policy as agreed in the Maastricht Treaty. Apart from granting the ECB responsibility regarding the smooth operation of euro-area payment systems, the ECB was only assigned an ancillary role in financial stability policy more broadly. Article 127 TFEU merely states that "the ESCB [European System of Central Banks] shall contribute to the smooth conduct of policies pursued by the competent authorities relating to the prudential supervision of credit institutions and the stability of the financial system." One reason for this arrangement was that the national authorities of some important member countries strongly resisted any loss in sovereignty in this policy area, additional to their perceived loss of monetary sovereignty (Bernholz 1998; Dyson and Featherstone 1999; Lastra 2003; James 2012). Based on its own historical experience, the Bundesbank considered it unwise to risk tarnishing the ECB's reputation and independence by having the central bank get too deeply involved in the potentially messy business of rescuing failing banks it has supervisory authority over. ${ }^{13}$

But far more than envy and vanity is actually involved here. Practical reasons also speak in favor of maintaining supervisory and LOLR authority at the national level. At least as long as banks are largely national institutions, the national authorities will simply be more familiar with their national banking institutions (Schoenmaker 1997). Notice that this rationale turns into an argument for centralized banking supervision at the union level as pan-European banks arise and banking systems become deeply integrated. One issue then is whether to rely on the ECB as chief bank supervisor or some other institution. Another issue is how to deal with the fact that Europe's peculiar EMU is not a fiscal union.

Ultimately the lack of federal fiscal resources to backstop financial stability policy provided the most fundamental reason for keeping authority over financial stability policy largely at the national level at the outset. For if a common supervisory authority with primary responsibility

\footnotetext{
${ }^{13}$ As previously mentioned, the failure of Herstatt Bank in 1974 was the only case of any significance, a crisis that did not enhance the Bundesbank's reputation. Arguably, the absence of any major asset price bubbles and financial crises prior to the global crisis of 2008-09 in the post-WWII period is intimately related to Germany's export-led growth model, which relies on other countries to stimulate domestic demand sufficiently to enable German exports to be the key driver of German GDP growth. For a central bank that derives its reputation squarely from maintaining price stability this represents a convenient low-risk strategy.
} 
for financial stability were to incur losses in the context of some financial rescue event, the question would arise whether and how those losses should be shared among the member states. If the ECB itself were that authority, its NCB owners (and, indirectly, the euro-area member states) would need to settle that matter, including the question of central bank recapitalization, should such a need arise.

In the absence of a federal fiscal funding authority, this issue can only be preempted if any fiscal impact of financial rescue measures were borne by the respective national fiscal authorities in the first place. In other words, in case any central bank losses arise in the context of some financial rescue event and LOLR activity, it is the national finance ministry concerned that will have to make the respective national central bank whole. In turn, this implies that if the national authorities have to pick up the bill, they will almost certainly want to make sure to also have supervisory authority over the potential recipients of emergency liquidity and/or solvency support (Goodhart and Schoenmaker 1995; Schoenmaker 2000). There is a patent two-way connection between financial supervision and fiscal backup resources.

As will be discussed below, the rules agreed upon for the sharing of monetary income among euro member NCBs together with the "monetary financing" prohibition and principle of financial independence require exactly the kind of fragmented/segmented arrangement just identified here featuring national solvency support of banks and NCBs. Central banks will be keen to make sure that any lending-of-last-resort activity at either the national or union level is conducted in a way that prevents central bank losses from occurring in the first place.

Apart from the issue of national prestige, there was thus also a deeper reason for keeping the national central banks in place when the ECB and ESCB were established. And the NCBs were in fact kept in place with their varying historical responsibilities in the financial stability domain, with the ESCB statutes only requiring that the pursuit of any such responsibilities must not interfere with the objectives and tasks of the system and that any costs related to those other functions must be borne nationally (Padoa-Schioppa 2004).

As one further consequence of the absence of fiscal union and related continuation of national central banks, the euro monetary union does not consist of a unified (or one-tier) central bank balance sheet providing the ultimate settlement asset for a unified area-wide payment system. Instead, a two-tier system of central bank balance sheets exists in the euro area, providing for 
payments and settlement across the currency union by interlinking national payment systems through a facility that is known as the Trans-European Automated Real-time Gross settlement Express Transfer (TARGET2) system. The area-wide payment and settlement system supported in this peculiar way is a precondition for money market integration across the area which, in turn, is a precondition for the implementation of the common and uniform monetary conditions across the whole area.

In short, the outstanding fact of monetary union without fiscal union ultimately also explains a number of other peculiarities of the EMU, particularly the central bank system that allocates authority over financial stability policy at the national level (featuring the NCBs to varying degrees) rather than at the center, the ECB.

With fiscal policy remaining under national authority, the designers of the Maastricht Treaty were even more adamant about keeping the public finance domain of central banking - the government bank role - tightly constrained at both the federal and national levels, completely prohibiting any direct lending by the central bank system to the public sector. The aim here was to establish a water-tight separation between the (common) monetary policy and (national) fiscal policies, and wholly decouple public finances from money creation. As will be discussed in detail in the following, from the German perspective this aspired decoupling was seen as key to stemming any risk of fiscal dominance and guaranteeing the ECB's independence and monetary hegemony, considered vital preconditions for maintaining price stability.

In line with the factual situation of monetary union without fiscal union, the Maastricht Treaty features the legal fiction of monetary policy as being something that is wholly separate from economic (including fiscal) policy in general. In EU legal terms, monetary policy is an exclusive competence of the union, at least "for the Member States whose currency is the euro" (TEU Article 3). Economic policy, on the other hand, remains primarily a national responsibility (TFEU Article 2). The Treaty merely refers to "the definition of common objectives," specifically the "broad guidelines." Member states are just required to regard their economic policies as a "matter of common concern" and coordinate them closely (TFEU Articles 3 and 5, 119-121).

This institutionalized division of labor may seem like a clear-cut allocation of authority in their respective fields of policy conduct — and also a necessity in view of the fiscal-monetary divorce 
that is central to the Maastricht regime. Alas, the legal construct clashes with economic reality rather brusquely. The most important issue here is actually the objective of price stability itself. Price stability features among the set of union aims (objectives) laid down in TEU Article 3: the union "shall work for the sustainable development of Europe based on balanced growth and price stability." In addition, "stable prices," along with "sound public finances and monetary conditions and a sustainable balance of payments," are also mentioned as "guiding principles" for the activities of the member states and the union (TFEU Article 119). At the same time "maintaining price stability" is the "primary objective" of the monetary policy of the ECB, exercising the union's supposedly exclusive competence in this field. On the other hand, it is only without prejudice to price stability that the ECB is asked to "support the general economic policies in the union with a view to contributing to the achievement of the objectives of the Union as laid down in Article 3" (TFEU Article 127)—objectives mainly pursued by (coordinated) national economic policies.

In principle, a central bank does have direct power over its operational instruments of monetary control and their deliberate use towards steering its own balance sheet, if it so chooses. But the reality is that monetary policy does not have any direct and immediate control over price stability at all. Monetary policy works through the financial system and the economy. In particular, the application of monetary policy instruments can deliberately shape financial conditions in ways that condition economic performance, but still, any effects on price stability - the ECB's primary objective — only arise in very indirect and diffused ways, and only with "long and variable lags" (Friedman 1968). In other words, by its very nature, the monetary policy impact on price stability comes alongside other effects on the financial system and economy more broadly; effects at least some of which can also arise quite similarly from using other economic policies.

In particular, economic policy — other than monetary policy, that is - may not only have some targeted impact on the economy or specific economic variables, but affect prices as well. Such price effects can arise indirectly, as in the case of monetary policy itself. Or they may actually also arise in direct and immediate ways, specifically in the case of changes in indirect taxes and administered prices (see "tax-push" in section 2, above). In short, as far as policy objectives are concerned, the legal fiction established in the Maastricht Treaty bears little resemblance to the realities of economic and monetary policies in the real world. As soon as one looks beyond 
stated objectives supposedly justifying some specific economic or monetary policy measure, matters immediately become too complex to be separated into clean boxes titled either "economic" or "monetary" policy. As a result, the legal fiction of monetary policy as something that is wholly separate from economic policy can give rise to serious problems when legal judgments are sought concerning specific policy measures, whether they constitute either monetary or economic policy, and whether or not some measure is really covered by the exclusive competence for monetary policy conferred to the ECB in particular.

The European Court of Justice's (ECJ) landmark ruling of 2012 on the European Stability Mechanism (ESM) is at the heart of the matter here (ECJ 2012). The ESM was established in September 2012 as a permanent risk-sharing facility that can provide ("bail-out") loans to member states that have lost access to market funding. (It replaced the temporary European Financial Stability Facility [EFSF] established in May 2010). In its so-called "Pringle decision" the ECJ confirmed the legality of the ESM. It determined, first, that the ESM constitutes economic policy but not monetary policy and, second, that the ESM does not violate Article 125 TFEU (the so-called "no-bail-out clause"), which lays down that neither the union nor member states shall be liable for or assume the commitments of their partners' public authorities.

In the Pringle case, the ECJ was called upon to judge whether the ESM might conflict with the union's exclusive competence in monetary policy assigned to the ECB. The court's assessment first focuses on policy objectives. In its ruling the court determines that the objective of the ESM does not concern price stability, but securing the financing needs of the members' public sectors, which, in the ECJ's eyes, makes it the subject of economic policy. The court then also addresses the issue whether any indirect effects on price stability would concern this assessment, but determines that what matters is that the ESM, in contrast to monetary policy, does not constitute a direct measure to maintain price stability (see ECJ 2012; Sester 2012; Fisahn 2014).

The ECJ's ruling based on this artificial distinction helped save the ESM, but by creating leeway as to what constitutes the realm of economic policy, the ECJ's ruling risked squeezing monetary policy into too tight a spot. The point is that the ECB may have the exclusive competence over monetary policy, but - beyond legal fiction - the ECB clearly does not have any direct controls to maintain price stability at its disposal. Whatever the ECB does will only 
have indirect effects on price stability itself. The ECB may even justify its measures with reference to monetary policy and its primary price stability objective, but given that its measures affect financial conditions and the economy — and only work, if they do, namely by doing sothe legal fiction underlying the Maastricht Treaty and featuring in the Pringle ruling has left the ECB exposed to legal challenges regarding its inevitable policy impact on the financial system and the economy. Both the immediate and the wider effects and repercussions of monetary policy may easily be perceived as constituting economic policy. As soon as some party does not like any of those effects, it can challenge the ECB as overstepping its monetary policy mandate, putting the independent ECB under court ruling, it seems. This situation is absurd and in utter conflict with the spirit of the Maastricht Treaty and its emphasis on the supposed utmost importance of central bank independence.

It is particularly ironic that the fiercest challenges of the ECB's independence have come from Germany. It its preliminary ruling of January 2014 on the ECB's Outright Monetary Transactions program (OMT), Germany's (Federal) Constitutional Court (GCC) suggests that the ECB may be overstepping its monetary policy mandate (ultra vires; acting beyond the ECB's legal authority). ${ }^{14}$ As was the case with its forerunner model, the Securities Markets Programme (SMP) of 2010, the OMT involves ECB purchases of particular member states' government bonds in secondary markets, raising the suspicion of "monetary financing" to begin with. Moreover, since purchases would be undertaken in circumstances of market stress that see member states without access to market funding (on sustainable terms), the further suspicion arises that OMT may be similar to ESM programs and hence constitute economic policy. So the issue with OMT is the exact opposite of the earlier Pringle case: Does the OMT really constitute monetary policy proper rather than economic policy?

The GCC's opinions and rulings may at first appear to be irrelevant. The ECB and its monetary policy are a European matter and do not fall into the GCC's competence, whose remit is to enforce the norms of Germany's Basic Law ("Grundgesetz"); for the first time in its history the GCC has actually referred a case, the ECB's OMT, to the ECJ for a ruling.

\footnotetext{
${ }^{14}$ See Deutsche Bundesbank (2012), Siekmann and Wieland (2013), German Constitutional Court (2014a), Fisahn (2014), Mayer (2014), Mody (2014), and Winkler (2014a,b).
} 
The GCC requested that the ECJ looks closely into certain aspects of the OMT program, broadly speaking, whether OMT constitutes economic (rather than monetary) policy and/or monetary financing. Beginning with the economic policy question, the GCC's preliminary ruling follows the reasoning of the ECJ's Pringle decision closely. Acting largely on the expertise provided to it by the Bundesbank (see Deutsche Bundesbank 2012; Weidmann 2013a), which itself openly opposed the OMT (as had previously been the case with the SMP), the GCC identifies a number of aspects of the OMT that may seem to disqualify the program as monetary policy and hence as part of the ECB's exclusive competence. The challenged attributes of OMT are: that OMT is conditional on the member state that is the recipient of OMT support also being, in parallel, a ESM-program country; that OMT selectively supports certain countries rather than all member states equally; and that the somewhat lighter conditions of OMT compared to the ESM may lead to circumvention of the stricter ESM conditions. An important assumption underlying the GCC's reasoning appears to be that market prices are always correct and that a central bank must not challenge the wisdom of the market.

It is important to appreciate that confirmation of the GCC's opinion on OMT would severely constrain the ECB's monetary policy powers to influence financial conditions, especially under extreme conditions. With loss of control over its own balance sheet in pursuit of its mandate, the ECB's status of independence would be severely diminished. It would be the court(s) that assess whether certain ECB measures may be construed as measures that are equivalent to economic policy. In this case, one could only hope that the opposite kind of challenge would land at the ECJ's doorstep, asking the court to clarify whether it was the spirit of the Maastricht Treaty to establish an impotent central bank that lacked the monetary instruments to fulfill its price stability mandate.

Fortunately the recently issued opinion by the ECJ's General Advocate, Cruz Villalón, of January 14, 2015 has shed some important light on the situation (ECJ 2015). Regarding the legal fiction of monetary policy as something wholly separate from economic policy, the General Advocate clarifies that: 


\begin{abstract}
Although it may appear self-evident, it is important to make the point that monetary policy forms part of general economic policy. The division that EU law makes between those policies is a requirement imposed by the structure of the Treaties and by the horizontal and vertical distribution of powers within the Union, but in economic terms it may be stated that any monetary policy measure is ultimately encompassed by the broader category of general economic policy. That connection between the two policies was highlighted by the Court of Justice itself, and by Advocate General Kokott in her View, in Pringle, when it was stated that an economic policy measure cannot be treated as equivalent to a monetary policy measure for the sole reason that it may have indirect effects on the euro. That reasoning is entirely valid if turned around, as has been pointed out by the ECB, the Commission and the majority of the Member States that have participated in these proceedings, since a monetary policy measure does not become an economic policy measure merely because it may have indirect effects on the economic policy of the Union and the Member States. (ECJ 2015, paragraph 129)
\end{abstract}

The General Advocate then goes on to effectively provide a broad set of requirements for any ECB measure to qualify as monetary policy, namely:

\begin{abstract}
in order for a measure of the ECB actually to form part of monetary policy, it must specifically serve the primary objective of maintaining price stability and it must also take the form of one of the monetary policy instruments expressly provided for in the Treaties and not be contrary to the requirement for fiscal discipline and the principle that there is no shared financial liability. If there are isolated economic-policy aspects to the measure at issue, the latter will be compatible with the ECB's mandate only as long as it serves to "support" economic policy measures and is subordinate to the ECB's overriding objective. (ECJ 2015, paragraph 132)
\end{abstract}

This statement also refers to the ECB's "supportive" role in economic policy. This is important to the extent that the GCC's challenge of the ECB was partly influenced by the fact that ECB communications around the time when the OMT was launched focused on the goal of preserving the euro (ECJ 2015, paragraph 137). This goal cannot be easily subsumed under the price stability mandate of monetary policy; preventing nuclear war or climate change would then equally qualify as considerations. Preserving the euro is ultimately the political authorities' responsibility, economic rather than monetary policy. The General Advocate's opinion highlights (see paragraphs 19 and 20) that the political authorities had repeatedly stressed that the euro was irreversible (ECJ 2015, paragraph 20). In that sense, the ECB communications to that effect surrounding the OMT merely provided support for the declared economic policy objective. Arguably, the ECB's communications greatly enhanced the effectiveness of the OMT 
threat precisely because they reached beyond monetary policy proper to underline what was at stake, but the point remains that ECB measures can only receive cover under the ECB's supportive role as long as there is a certain economic policy in place that receives its support and that is subordinate to the ECB's price stability mandate.

More generally, the ECB has to make sure to frame and rationalize its measures strictly in terms of monetary policy with its primary price stability mandate, as it usually does. The critical issue in this context concerned the argument that OMT was designed to restore the proper functioning of the transmission mechanism. The GCC's opinion challenged the idea of distorted and explosive risk premia, and that a central bank should seek to correct such developments. By contrast, the ECJ's opinion acknowledges that possibility and, on that basis, follows the ECB's argument that the purpose of OMT is to unblock the transmission mechanism, which also justifies its selectivity ${ }^{15}$ :

selectivity is merely the logical consequence of a programme seeking to remedy a situation in which the monetary policy transmission channels are blocked in various Member States. The fact that there may be changes in the market or that the government bonds of other States may be placed at a disadvantage does not affect the classification of the OMT programme as a monetary policy measure, since it is only by targeting the programme at the bonds of the States concerned that the efficacy of the programme can be ensured. (ECJ 2015, paragraph 153)

\footnotetext{
${ }^{15}$ There is an important inconsistency in this argument, though. Given that one key underlying challenge in the euro area is to rebalance competitiveness positions (see section 4, below), financial fragmentation may be seen as part of the adjustment mechanism: countries under pressure to improve their competitiveness have to go through a process of relative deflation which, a cynic might argue, financial fragmentation only amplifies. Of course fragmentation starkly conflicts with the aspiration of financial integration and monetary policy singleness. But the main practical problem for the euro-area crisis countries is that the adjustment process is not taking place at an average area-wide inflation rate of 2 percent, but in an overall environment of stagnation cum "lowflation," if not deflation. As a result, relative deflation involves absolute deflation and hence excessive and needless socioeconomic hardship. In principle, the challenge for the ECB is as usual: to set a monetary stance that ensures price stability ( 2 percent average inflation) in the euro area as a whole. In theory, if the ECB's policy stance is not properly transmitted to certain countries going through a deflationary adjustment, it takes an extra dose of expansionary stimulus to produce sufficient inflation in member states that — by logical necessity — need to give ground with regard to their (intra-currency union) competitiveness. In practice, that may not be easily feasible, in particular if the member states that need to see reflation pursue outright deflationary economic policies. The notorious critique from the German side that ECB stimulus must not discourage needed structural reforms (i.e., wage cuts) may be understood from this (cynical but, in this respect, consistent) perspective. The true inconsistency in the German position is to ignore and renege on the complementary need for German reflation. This is not a game of chicken though. If euro-area crisis countries follow their deflationary prescriptions while Germany stays the course, the risk is that the currency union will ultimately sink into deflation-revealing that the ECB emperor has no clothes.
} 
Suffice to add here that, while the ECJ's recent opinion may have cleared the legitimacy of OMT as a monetary policy measure, the actual implementation of OMT remains conditional on an ESM program being in place which, in turn, presupposes that the euro-area member states' political authorities agree on an ESM program for some particular member country in crisis. ${ }^{16}$

In addition to the above complexities regarding the ECB's exclusive competence in the field of monetary policy and its primary price stability objective, other more immediately relevant practical constraints relate to Articles 125 and 123. Article 125 (aka the "no bail-out" clause) states that neither the union nor a member states shall be "liable for or assume the commitments of central governments, regional, local or other public authorities, other bodies governed by public law, or public undertakings of another Member State, without prejudice to mutual financial guarantees for the joint execution of a specific project." Article 123 (aka the "monetary financing" prohibition) strictly rules out "any overdraft facilities or any other type of credit facility" to the benefit of any government. Once again, by interpreting Article 125 liberally in the Pringle case, the ECJ has tightened the screws on Article 123. With regard to Article 125, the ECJ ruled that, while assuming the "commitments" of other member states would be prohibited, said Treaty provision does not rule out "financial assistance" in the form of "credit lines" (loans) granted to a distressed member to be repaid over time with "an appropriate margin."

The ECJ's distinction highlights that so-called "bailouts" organized as loans are not to be confused with gifts (or the assumption of commitments). It also suggests that the payment of ("appropriate") loan interest means that there is no implicit fiscal transfer involved either. The ECJ took comfort from the fact that Article 122 permits financial support to partner governments in case of circumstances that are beyond their control. ${ }^{17}$ But in the same context the ECJ highlighted and explicitly denied that the ECB might have any leeway of this kind at all when it comes to Article 123. The recent ECJ ruling underscored this point once more (see ECJ 2015, paragraph 220). The ECB will therefore want to be extremely cautious in this regard.

\footnotetext{
${ }^{16}$ German finance minister Wolfgang Schäuble explicitly stated his opposition to OMT indicating that he would stall approval of the needed ESM program, which would seem to imply that OMT is stillborn despite a favorable ECJ ruling. See Hennigan (2014) and CESifo (2014).

${ }^{17}$ Article 122 TFEU foresees the possibility of financial assistance in crisis situations "in a spirit of solidarity between member states." It was invoked as the legal basis of the European Financial Stability Mechanism in 2010. Article 125 TFEU itself refers to the possibility of "mutual financial guarantees for the joint execution of a specific project."
} 
This issue can create certain practical challenges. On the one hand, issuing government debt securities constitutes a principal source of state financing. On the other hand, a central bank must buy some assets in order to issue its monetary liabilities, and many central banks have traditionally held government bonds as an asset purchased even in the context of their routine monetary policy conduct. In general, there is no harm done whatsoever by this standard practice, but as we saw above, it was part and parcel of Bundesbank culture to scorn any build-up of public debt securities in its portfolio - to preempt any suspicion of monetary financing. It is therefore not much of a surprise that the second part of the legal challenge of OMT presented by the GCC focuses on the perception that OMT might constitute monetary financing.

In the following I will try to further illuminate the kind of peculiar constraints that can arise from specific Treaty provisions related to monetary financing concerns with respect to the ECB's monetary policy toolkit itself.

To repeat, these specific Treaty provisions were intended to tightly separate monetary policy from fiscal policy: the fiscal-monetary divorce that uniquely characterizes Europe's currency union. The ECB has exclusive authority over monetary policy only, but fiscal policy is a national competence. Europe's EMU is not a fiscal union. Specifically it is not a transfer union. It turns out that the lack of fiscal union can constrain how the ECB's balance sheet might be used without being interpreted as facilitating government funding and cross-country fiscal transfers. ECB measures will raise a red flag as soon as they may appear to involve redistributive effects or otherwise appear to cross the borderline with fiscal policy.

This whole matter is of course something of a farce given that monetary policy does always have (re-)distributive implications. Changes in interest rates (and financial conditions more broadly) inevitably affect creditors and debtors in opposite ways. Among other things, and quite apart from seigniorage itself, monetary policy inevitably and significantly impacts fiscal policy through its impact on the interest burden on the public debt, not to mention the repercussions that economic activity has on the overall budgetary position. In the euro context some of the most intriguing issues arise with regard to monetary income (seigniorage) and the possibility of central bank losses and potential need for recapitalization. Specific rules for income, risk, and loss sharing were laid down in the Maastricht Treaty. The ECB puts itself under risk of legal 
challenge if its policy measures are perceived as contradicting those rules, especially related to purchases of government bonds.

This may not be obvious at first because, while TFEU Article 123 prohibits overdrafts and any other credit facilities as well as direct (primary market) purchases of public debt securities, purchases of public securities in secondary markets are clearly covered by Article 18 of the Statutes, which states that in the pursuit of its mandate and tasks the ECB "may operate in the financial markets by buying and selling outright (spot and forward) or under repurchase agreement and by lending or borrowing claims and marketable instruments, whether in euro or other currencies, as well as precious metals." The general wording of Article 18 would seem to offer a broad permission of secondary market purchases of government securities. And so Council Regulation No. 3603/93, agreed upon in December 13, 1993 as a footnote to the Maastricht Treaty, added the caveat that "purchases [of government bonds] made on the secondary market must not be used to circumvent the objective of [Article 123]" (Council of the European Union 1993). The same resolution also clarified that any public sector obligations visà-vis third parties are covered under this rule, too. This "footnote" opens up considerable scope for interpretation.

The most critical issue appears to be whether the objective of the central bank's actions is the implementation of monetary policy in the pursuit of its mandate - or the provision of credit to the government. In view of the ECB's status of independence it would appear that the ECB alone has to decide and communicate what the objective of its measure may be at any time. The GCC challenged the ECB's monetary policy motivations with regard to the OMT (as with the earlier SMP), second guessing the ECB and suggesting that the real aim of the OMT was to transform the ECB into a lender of last resort for governments. The ECJ's preliminary ruling of January 2015 features the following response:

Besides the fact that it must strictly adhere to the objective of ensuring price stability, a
further characteristic of the ECB is that it has a high degree of functional as well as
organic independence [paragraph 108]. [...]The ECB must accordingly be afforded a
broad discretion for the purpose of framing and implementing the Union's monetary
policy. The Courts, when reviewing the ECB's activity, must therefore avoid the risk of
supplanting the Bank, by venturing into a highly technical terrain in which it is
necessary to have an expertise and experience which, according to the Treaties, devolves
solely upon the ECB. Therefore, the intensity of judicial review of the ECB's activity, its
mandatory nature aside, must be characterised by a considerable degree of caution
[paragraph 111]. [...] it should also be acknowledged that, in any evaluation of its 
assessments as to matters of fact, the ECB should be afforded a considerable degree of deference. (ECJ 2015, paragraph 138)

Even if it were accepted that the ECB must not be easily challenged regarding the objectives of any of its monetary policy measures, this still does not settle the issue of OMT as monetary financing. OMT, like other monetary policy measures, affect income, risk, and loss-sharing within the Eurosystem. In this regard, in addition to Articles $123^{18}$ and 125 , the especially pertinent provisions in the Maastricht Treaty may be identified and summarized as follows:

- TFEU Article 130, designed to secure the ECB's status as the world's most independent central bank, prohibits central bankers from seeking or taking instructions from the euroarea political authorities. The Treaty also required that the Statutes of the NCBs were amended accordingly. And, starting with the European Monetary Institute's (EMI) Progress towards Convergence Report of 1995, regular assessments have been made (later by the ECB itself) as to whether the statutes of the NCBs and specific measures are in line with what may be seen as minimum legal requirements with regard to their independent status. For this purpose the EMI developed a list of features that might constitute conflicts with the required status of independence, distinguishing between institutional, personal, functional, and financial independence, of which the latter two attributes are particularly pertinent here. The requirement of financial independence calls for NCBs to "be in a position to avail themselves of the appropriate means to ensure that their ESCB-related tasks can be properly fulfilled." In cases where the national authorities are in a position "to exercise influence on the determination of an NCB's budget or the distribution of profit," the EMI $(1996,103)$ states that "the relevant statutory provisions should contain a safeguard clause to ensure that this does not impede the proper performance of the NCB's ESCB-related tasks." The ECB has specified its views on this matter in great detail in its own 2012 Convergence Report, stating that: "The concept of financial independence should be assessed from the perspective of whether any third party is able to exercise either direct or indirect influence not only over an NCB's tasks but also over its ability to fulfill its mandate, both operationally in terms of manpower, and financially in terms of appropriate financial resources" (ECB 2012, 26). In practice, the NCBs (like the ECB) enjoy budgetary authority (and significant discretion) over their expenses and the determination of their profit, capital, and provisions, etc. The requirement of functional independence also relates to Article 14.4 of the Statutes.

\footnotetext{
${ }^{18}$ The prohibition of any measure establishing "privileged access" to financial institutions by any euro-area public sector institutions, laid down in TFEU Article 124, may be seen as an extension of the monetary financing prohibition and is thus also relevant. It is however not considered monetary financing if financial institutions decide to purchase government bonds and then use them as collateral in ECB refinancing transactions based purely on their own business calculus.
} 
- ESCB Statutes Article 14.4 permits that the NCBs may fulfill national central banking functions as long as they do not conflict with the system's objectives and tasks. It stipulates that "national central banks may perform functions other than those specified in this Statute unless the Governing Council finds, by a majority of two thirds of the votes cast, that these interfere with the objectives and tasks of the ESCB. Such functions shall be performed on the responsibility and liability of national central banks and shall not be regarded as being part of the functions of the ESCB" [emphasis added]. This article covers the NCB's role as lenders of last resort in the course of Emergency Liquidity Assistance (ELA) to banks.

- Finally, ESCB Statutes Articles 32 and 33, which concern the sharing of NCBs' monetary income and the ECB's net profits and losses as based on their paid up shares in the capital of the ECB (Articles 28 and 29). Article 32 of the Statutes identifies the income accruing to any particular NCB in the performance of the system's monetary policy functions with reference to the (to be earmarked) assets held against notes in circulation and deposit liabilities against credit institutions (net of interest paid on those deposits). By implication, any potential profits or losses that are unrelated to the performance of the system's monetary policy function are not supposed to be shared. This is also made clear by the caveat that NCBs may be "indemnified against costs incurred in connection with the issue of banknotes or in exceptional circumstances for specific losses arising from monetary policy operations undertaken for the [Eurosystem]." As far as the ECB's profits and losses are concerned, Article 33 of the Statutes states that, beyond transfers to a general reserve fund, capped at 20 percent of the annual profit and 100 percent of the ECB's capital, any remaining net profits are shared among its NCB owners according to the ECB capital subscription key. This principle also applies to the sharing of any ECB losses that exceed the general reserve fund. While the NCBs' liability for ECB losses appears to be capped by the monetary income of the relevant year, Article 28 states that the Governing Council may decide to increase the ECB's capital (originally set at $€ 5,000$ million); hence, in practice, an increase may amount to capital replenishment.

Over the years the ECB has developed an extensive interpretation of the monetary financing prohibition and the related principle of financial independence to ensure their strict application. The ECB assesses the issue in the context of its regular Convergence Reports. The ECB has issued numerous opinions in the context of its consultation by member states on draft national legislation. And the ECB also regularly reports on its monitoring role and specific compliance issues in this area, including secondary market purchases of public debt instruments, in its Annual Reports under "Other Tasks and Activities" (chapter 2, section 6). The standards or principles that seem to guide the ECB's assessments and opinions are twofold: first, that, beyond the regular distribution of monetary income toward national budgets, central bank 
measures must not alleviate in any way (and not even temporarily other than by accident) the need to finance government expenditures by either taxes or sovereign debt issuance (or provide balance sheet support, back guarantees, or cover losses, etc.); and, second, that in assessing the distribution of monetary income towards national budgets the central bank's preexisting financial position must be at least maintained or, if needed, restored to that level. We begin by presenting some ECB opinions on the matter before evaluating the economic content.

The incidences of actual conflicts with Article 123 reported by the ECB are generally minor ones. For instance, on one occasion the Bank of Italy was found to have provided monetary financing by remunerating government deposits at above-market rates. On another occasion the Dutch central bank reported a noncompliance issue (lasting for one day only) regarding an intraday credit facility. In its 2013 Annual Report the ECB for the first time appears to have detected a more serious conflict, or at least potential for conflict, relating to the Irish banking crisis, stating that "the liquidation of the Irish Bank Resolution Corporation (IBRC) raises serious monetary financing concerns. These concerns could be somewhat mitigated by the disposal strategy of the Central Bank of Ireland" (ECB 2014, Annual Report 2013, 110). Apart from this somewhat obscure hint, the ECB has remained conspicuously silent in its main publications on the issue of ELA, an issue which will be taken up below.

Other relevant issues feature in the bank's opinions on proposed or drafted EU and national legislations in its areas of responsibility, also reported on in its Annual Reports. ${ }^{19}$ For instance, regarding the transfer of income accruing from the Securities Markets Program portfolio by the Bank of Greece to the Greek state, the ECB (2013, CON/2013/15) emphasizes that only profits that are "fully realized, accounted for, and audited" are eligible for distribution as part of the NCB's normal profit distribution, asking legislators for further clarification that "profits may only be transferred if accumulated losses from previous years were covered and applicable financial provisions created." This case illustrates that the ECB does not tolerate that the

\footnotetext{
19 "In connection with the global financial crisis, the ECB issued a large number of opinions, as it did in 2008, on proposed national rescue measures concerning state guarantees to financial institutions, the recapitalization of banks, special support to deposit guarantee schemes and, in particular in the course of the second half of the year, the establishment of impaired asset schemes (such as those in Germany and Ireland). The ECB concluded that the proposed new schemes, or the extension of earlier schemes introduced in 2008, permitted the implementation of the single monetary policy and safeguarded the NCBs' independence. Furthermore, the schemes were found to comply with the monetary financing prohibition, in particular in all cases where the proposed rescue operations foresaw a role for the respective NCB" (ECB 2010, Annual Report 2009, 127).
} 
financial position of a central bank might fall lastingly below some preestablished/preexisting level.

More closely relating to the financial stability domain and NCB's role as national LOLR, the ECB observes in an opinion made in request of the Polish Parliament that it "has consistently stated in its convergence reports and its opinions that national legislation which provides for the financing by national central banks (NCBs) of credit institutions, other than in connection with central banking tasks, in particular to support insolvent credit or other financial institutions, is incompatible with the monetary financing prohibition. The provision of liquidity in exceptional circumstances and on a case-by-case basis to temporarily illiquid but solvent credit institutions constitutes an inherent central bank task. Solvency support to credit or other financial institutions is a State task however, and may not be assumed by an NCB" (ECB 2013, CON/2013/5; emphasis added). The ECB stresses here that central bank support can only take the form of temporary liquidity provision while any solvency support must be covered by the respective national government. ${ }^{20}$ Using the central bank's balance sheet instead of the government's in closing any solvency gap would amount to monetary financing on the ECB's view.

This particular point is also underlined by a more recent statement appearing in the ECB's 2013 Annual Report concerning the financial independence of central banks in general:

"Governments can contribute to the financial strength of the central bank by guaranteeing to cover any losses it may make and, eventually, to recapitalize it when necessary (i.e., what is known as 'fiscal backing') and by stipulating in law that the central bank will have sufficient resources to perform its tasks in the fulfillment of its mandate (financial independence and a prohibition on performing tasks not covered by its mandate)." Regarding the Eurosystem more specifically, the ECB continues there by observing that specific Treaty provisions "preclude the monetization of sovereign debt, for instance by providing Member States with financial contributions in excess of their shares in the central bank's profits realized in the respective financial year” (ECB 2014, Annual Report 2013, 40).

\footnotetext{
${ }^{20}$ As the European Commission exercises authority over the "state aid" question, this adds even more complexity to the matter.
} 
In summary, on the ECB's strict interpretation of the monetary financing prohibition and principle of financial independence, the Eurosystem's financial contribution to euro-member public finances must be strictly limited to any realized central bank profits, and on a year-byyear basis. While acknowledging the possibility of central bank losses and hence temporary slippage, the ECB's position implies that central banks' capital must be held at, or restored to, some particular preexisting/predetermined level (as decided by the central bank itself).

The ECB has been attacked on its insistence on central bank capital (Whelan 2012b; De Grauwe 2014). In fact, there is the theoretical argument that central banks may not need capital at all in order to function effectively (Buiter and Rahbari 2012a; see also Bindseil, Manzanares, and Weller 2004). This argument is principally correct up to a point and especially for the case of a sovereign state fiscally backing its own national central bank in the conduct of monetary policy, standing ready to supply its central bank with public debt securities to either provide earning assets or as market material to mop up any excess liquidity should such a need arise. In general, the tolerated rate of inflation, GDP growth, financial sector shape and development, and reserve currency status define the limits to potential seigniorage earnings over the lifetime of a currency and, in principle, there may be important scope for intertemporal flexibility in its exploitation and use by the state issuing the currency at hand.

In the standard case of a sovereign state, optimal intertemporal use of seigniorage is a decision that will ultimately be made by the political authorities. In the context of the euro area, De Grauwe's (2014) apparent free-lunch argument is missing the important reality that the euro currency union is not a sovereign state or fiscal union. According to the ECJ's Pringle decision the political authorities may agree to provide financial assistance, but the same ruling underscored that the Treaty precludes the use of the ECB's balance sheet for that purpose (once again confirmed by the ECJ's ruling of January 2015). The issues of monetary financing and implicit fiscal transfers open up a Pandora's Box of potential legal challenges and uncertainties.

Consider first the normal case of a central bank of a sovereign state departing from its standard "fair-weather" procedures of providing liquidity passively and in the amount demanded by the banking system, earning seigniorage income (largely determined by the size of its balance sheet and the interest rate spread of income-earning assets over its liabilities), which it routinely remits to the treasury department. In this normal state of affairs the central bank leaves the 
(micro) credit/finance allocation function wholly to the market and merely tries to manage the (macro) aggregate provision of finance to the economy as a whole by setting its policy rate (and financial regulations) in line with macroeconomic (and financial stability) requirements.

If the central bank then embarks on actively providing excess liquidity by purchasing additional assets as part of a monetary policy initiative designed to drive down longer-term yields (QE), its monetary income will tend to rise in the short run. Its income will stay elevated for as long as the central bank's balance sheets are "bloated" (compared to the trajectory of passive "fairweather" expansion) and its assets yield more income than its liabilities.

This outcome would change if the economy recovered and interest rates returned to "normal" levels before the central bank's (QE-bloated) balance sheet returns to its normal (passive) trajectory. In this case the central bank would need to mop up any excess liquidity as part of its return to positive interest rate levels and standard monetary policy operating procedures. It would either need to sell assets (if it has assets to sell, assets that were not defaulted on) or issue its own nonmonetary (i.e., interest yielding) liabilities. In the former case it would likely record capital losses; in the latter reduced or negative monetary income. Profit accounting would either show deterioration in its preexisting financial position and/or lower current monetary income.

In general, the central bank may be in a position to gradually restore its prior financial position through future seigniorage earnings, but from the Treasury's perspective it is clear that the "good years" of augmented monetary income through QE monetary expansion would be followed by "bad years" of reduced monetary income once the economy and interest rates return to normal. In short, there is an intertemporal seigniorage shifting, a borrowing from the future, involved.

Another relevant case is when the central bank is called upon to provide emergency loans to some troubled financial institution as LOLR. In principle, ELA, too, may result in a temporary income boost and/or realized capital gains, if things go well. But ELA can also lead to losses when things go bad. In case of a sizeable default on LOLR loans, the central bank might end up with a hole on the asset side of its balance sheet and a negative equity position (indicating insolvency). 
Negative equity may not have any immediate monetary policy implications if mopping up excess liquidity is either not an issue or the central bank has remaining assets to sell, or can issue its own nonmonetary liabilities. In general, the central bank could then restore its preexisting financial position through future seigniorage income earnings. The fiscal implications would be as above: the Treasury (taxpayer) would suffer lower future monetary income as a consequence of the losses incurred on its rescue operations.

Or could the central bank not simply operate with negative equity from now on and continue distributing (reduced) monetary income earned on its (reduced) assets to the Treasury as if nothing had ever happened? In principle, it could do that too - up to a point. For once the central bank's assets shrink (through losses) to the point where its income earnings no longer cover its operating expenses, the central bank would need to start "printing money" to cover its expenses. This would compromise its monetary policy implementation unless it issues nonmonetary liabilities in parallel, which might push the central bank into a Ponzi game-like position. The central bank's reputation and credibility will likely take a hit long before this point is reached. A central bank will not wish to be perceived as following such a trajectory. As a central bank's positive equity position melts away and turns negative it gets closer to the point of losing solidity. Any existing capital base can only be lost once.

This, then, illustrates the case for central bank recapitalization by the treasury: for which purpose the treasury simply hands over (income-earning) government bonds to its central bank, filling the hole that resulted from losses, and restoring a positive equity position. This would seemingly be for free since the treasury pays interest on its debt to the central bank, which the central bank returns to the treasury as monetary income. Not quite, and for two reasons. First, the central bank returns the interest it earns net of any operating expenses. And an important part of financial independence is that the central bank determines its own operating expenses (to forestall the perceived threat that the treasury might pressure the central bank into pursuing more convenient monetary policies). Second, recapitalization by the treasury does not nullify the fact that the central bank has lost income-earning private-sector assets.

We may add here that should the central bank's losses instead result from government debt held, that is, due to the default of the national government, the hole could be filled by "fresh" debts issued (or handed over to the central bank) by its national government. This scenario has neutral 
fiscal implications as far as the central bank's balance sheet and income statement are concerned unless the developments that led to the default also saw the central bank expanding the monetary base, with a subsequent need to mop up some excess liquidity through selling part of the "fresh" government bonds in the market. In this case, the government would have effectively failed to default on that part of its debt, as any market sale by the central bank would lead to "debt resurrection."

The situation is far more complex for the ECB and Eurosystem given the lack of fiscal union and the above specific Treaty provisions put in place to prevent both monetary financing and cross-country fiscal transfers, while monetary income is shared according to a predetermined formula based on the ECB's capital key. Regarding the distribution of monetary income arising from monetary policy measures that expand the system's balance sheet, it does not matter, in principle, whether government debts are purchased by the ECB or NCBs. In this case, the Eurosystem's monetary income is shared according to the ECB's capital key anyhow. Redistributive effects (fiscal transfers) may however be said to arise if bond purchases are not made in line with the ECB's capital key and/or if yields on government debt securities purchased by the system differ among members at the time of purchase. There would be implicit transfers from member states with ECB purchases above its capital key share to those below their share in the former case. There would be implicit transfers made by high-yield member states toward lower-yield member states in the latter. ${ }^{21}$

By contrast, in case of nonmonetary policy measures any income is not shared but stays national. That does not rule out distributional issues by itself though. The Central Bank of Ireland's (CBI) part in the liquidation of the Irish Bank Resolution Corporation (IBRC; formerly Anglo Irish Bank) referred to in the ECB's 2013 Annual Report is a case in point here. Anglo was nationalized in 2009 as a consequence of the Irish property bubble burst. At the time the CBI provided $€ 40$ billion in ELA to prevent Anglo's disorderly default. As collateral backing of the emergency loan on the books of the CBI, the Irish government issued a "promissory note" to IBRC, which was to be repaid over ten years. When IBRC/Anglo was then wound up by the Irish government in 2013, it handed over government bonds to the CBI to fill the hole left on its

\footnotetext{
${ }^{21}$ In November 2012 euro-area member states (that were not themselves subject to a financial assistance program) committed to reimburse Greece "an amount equivalent to the income on the SMP portfolio accruing to their NCB as from budget year 2013” (Eurogroup 2012).
} 
balance sheet, as the original ELA loan backed by the promissory note was nonrecoverable. These bonds had a different payment structure from the original promissory note, providing some budgetary relief to the Irish government (Whelan 2012a, 2013a; Bibow 2013b).

But that is not the main point from a Eurosystem perspective. Rather, it can be argued that the Irish government bailed out Anglo's creditors and had the debt incurred in the process effectively monetized by the CBI, at least for the time until those bonds held by the CBI are repaid, which would undo the original liquidity creation undertaken in 2009 through ELA. How does this kind of "monetary financing" differ from standard Eurosystem liquidity creation/provision?

The Eurosystem's liquidity provision through (standard) monetary policy implementation is purely passive and in line with market-driven banking activity and liquidity demands across the currency union; in a sense it is "market neutral." Whether or not liquidity creation by the system may be in line with the ECB's capital key, any monetary income derived from it will be shared according to that key. By contrast, while meeting any specific needs for ELA is largely passive too, it is not market neutral in the above sense. Rather, owing to the idiosyncratic nature of demand for ELA provision, the central bank liquidity created thereby is regionally targeted and generally out of line with the ECB's capital key, while any benefits (or costs) derived from ELA are also not shared in line with that key either. Liquidity creation through ELA can be expected to at least partially, if not fully, "crowd out" liquidity creation through general monetary policy implementation. The relative growth of NCBs balance sheets is affected. There are (re-) distributional implications. This is inevitably the case if ELA is provided by an NCB rather than the ECB.

In the case of IBRC/Anglo, the specific benefit to Ireland is that Ireland, in effect, pays no interest on the government bonds handed over to the CBI (instead of selling them in the market, assuming that was an option). The benefit lasts until the bonds mature unless they are sold by the CBI in the market beforehand. At that time the CBI's balance sheet would shrink accordingly (and the earlier "crowding out" reverse and system-wide liquidity creation turn more "neutral"). If instead new debts were handed over again in lieu of repayment of the old debts, the monetization would be rendered quasi-permanent. So there are both issues of redistribution and (temporary vs. permanent) monetary financing involved. Presumably since 
national ELA provision can potentially also interfere with monetary policy (by affecting the liquidity creation of the Eurosystem as a whole), the Governing Council has the right to stop ELA by a two-thirds majority vote (ESCB Statutes Article 14.4). ${ }^{22}$

There may be benefits (interest savings) from national liquidity creation. On the other hand, there might also be losses incurred on the central bank's assets and a corresponding need arise for recapitalization.

To illustrate the case, assume the central bank only holds one type of asset. For instance, if the central bank only holds national public debt and the government defaults on its debt, recapitalization in the form of handing over "fresh" bonds in replacement of the old ones (defaulted upon) would be free and easy. This is different if central bank losses arise from default on either national private debt or foreign debts. In this case the government loses the income from the defaulted debt, which prior to default contributed to covering the central bank's operating expenses and provided seigniorage income, and ends up covering the central bank's operating expenses itself. In the case of default on national private debt there occurs a national redistribution between the private and the public sector. The central bank is not supposed to deliberately incur any loss on behalf of the state. In the case of default on foreign debt (public or private) held by the central bank, the redistribution through losses suffered by default of the debtor is cross-border in nature. Curiously, in Europe's EMU losses suffered by default on foreign public debts can raise concerns about both monetary financing and cross-border fiscal transfers, at least if euro partners' public debt is the issue, concerns that do not arise when foreign private debts or foreign public debts of non-euro partner countries are at issue.

In fact, there is the (extreme) view that monetary financing and fiscal transfers not only relate to actual losses, but also to the mere risk of potential losses. The GCC's (2014a) preliminary OMT

\footnotetext{
${ }^{22}$ The fact remains that the ECB did neither stop the Irish ELA at the time nor-whatever the obscure remark in its 2014 Annual Report - the later restructuring of the original promissory notes (turned into longer-term bonds). A related controversial issue is the role of the ECB, specifically its then-president J.-C. Trichet, in "convincing" Ireland to first bail out its foreign bank creditors (rather than default) and then end up applying for a bail-out from its euro partners itself; see Bastasin (2015), for instance. Recall that Germany nationalized its own Hypo Real Estate, which had extensive Irish exposures (Depfa). Here it is also of some interest that the Q\&A session following the ECB governing council meeting on March 5, 2015 in Cyprus suggests that the government of Cyprus submitted a request to the ECB to consider conversion of Cyprus' ELA loan into a long-term bond. Mr. Draghi's (2015d) response to the question reads: "I'm not sure I know anything about that." Curiously, Mrs. Georghadji, governor of the Central Bank of Cyprus, on the same occasion remarked however: "With regard to the second question concerning ELA, of course President Draghi was there in the meeting with the President." See also Chrysoloras and Georgiou (2014).
} 
ruling amounts to this position (see ECJ 2015, paragraph 238; resembling Bundesbank views on the matter). A related question concerns the pari passu clause (or: lack of preferential creditor status) and whether acceptance of pari passu, which leaves the ECB and NCBs obliged to accept a full or partial waiver of its rights in the context of a restructuring agreement, turns OMT (or a similar measure) into an indirect means of financing the debtor State, i.e., monetary financing.

The ECJ's opinion of January 2015 brought some clarity to these matters as well. Regarding the pari passu clause, the Advocate General argues that:

\begin{abstract}
Acknowledgment that the ECB does not have preferential creditor status contributes to ensuring a more effective normalisation of market prices for government bonds, which, in turn, contributes to ensuring their solvency in the medium and long term, with the resulting reduction in the risks entailed [ECJ 2015, paragraph 183] ... I take the view that pari passu clauses may be regarded as a means that seeks to ensure that the ECB disrupts the normal functioning of the market as little as possible, which, ultimately, involves a further guarantee of compliance with Article 123(1) TFEU. (ECJ 2015, paragraph 236)
\end{abstract}

Furthermore, the Advocate General rejects the view that the risk of potential default on public debts purchased by the Eurosystem as such would run foul to the monetary financing prohibition. The critical question is whether, at the time those assets are purchased, default is a certainty or a mere risk. The Advocate General concludes:

I consider, in short, that that intention on the part of the ECB has been sufficiently established for it to be concluded that a purchase of government bonds - even ones with a low credit rating - which may expose the ECB to a degree of risk of default, is not as such contrary, in the circumstances described, to the prohibition of monetary financing laid down in Article 123(1) TFEU. (ECJ 2015, paragraph 241)

This assessment also highlights a subtle technical point about timing. Recall the possible case of a NCB that entered into a loss-making transaction arising from writedowns on bank bonds in the context of a bank rescue. Any realized loss reduces the central bank's profit, which itself contributes to public finances anyway. One may at first be tempted to argue that there would be no net benefit to the respective national government compared to the case in which the government had provided the emergency loan directly to the bank that turned out to be insolvent. One issue is whether the central bank (instead of the treasury) entered the transaction 
in "good faith" or not. Only if a NCB (or the ECB itself) deliberately overpaid can this constitute a breach of the monetary financing prohibition. Another issue concerns timing: if the treasury itself provides an emergency loan (which later suffers default), it may have to immediately borrow in the market to obtain the cash. If, instead, the central bank provides ELA and then suffers a loss on it, this only reduces the income remitted to the treasury much later. If the sovereign faces temporarily impaired market access at the time of the emergency, this is a crucial difference, particularly as Article 123 strictly prohibits any central bank overdrafts to sovereigns. According to the Treaty, the NCB may only act as a LOLR to banks if it judges that liquidity rather than solvency is the issue, but the $\mathrm{NCB}$ cannot be LOLR to the sovereign under any circumstances. However deeply flawed the prohibition of any type of LOLR to sovereigns may be in theory, the practical ramifications are truly severe: the Treaty appears to preclude any intertemporal discretion regarding the use of central bank liquidity and seigniorage when it comes to supporting public finances in any conceivable way.

Note that the "timing" issue: ex ante market access versus ex post budgetary relief (amounting to either monetary financing or monetary income) just discussed also concerns the principle of financial independence per se, since central bank profits are only transferred (and provide budgetary relief) after the central bank has made sure that its own budgetary parameters were satisfied.

Finally, beyond all these nitty-gritty legalistic and technical questions, there looms the overarching more philosophical issue: monetary versus fiscal dominance. The principle of financial independence and the ECB's insistence on preserving some preexisting financial position ultimately also relate to the perceived omnipresent threat of fiscal dominance. Alarmed by the prospect of sizeable outright purchases of government bonds, Otmar Issing, the ECB's former chief economist, spells out German central bankers' supreme nightmare by its name when he asserts that:

\footnotetext{
the practice of quantitative easing via outright purchases of government bonds connects monetary policy and fiscal policy in a dangerous way. The cheap financing of public spending might be seen as an effective way to conduct deficit spending, since it makes the fiscal multiplier higher. However, there is a high risk that this situation would hardly create any incentives for fiscal consolidation. Fiscal dominance might be the consequence, which would make it extremely difficult for the central bank to get out of the trap. The independence of the central bank-de jure and/or de facto-would be under threat. (Issing 2014, 5)
} 
Bundesbank president Jens Weidmann expressed the same fears by noting the central bank would no longer be in a position of "calling the shots" (Weidmann 2013). ${ }^{23}$

In the case of so-called paper (or: fiat) currencies the potential threat of fiscal dominance cannot be brushed aside offhand; rampant use of the "printing press" to fire unbounded fiscal expansion and hyperinflation are conceivable in principle and historical precedents exist. But neither can the opposite threat of insufficiently accommodative monetary policy paired with fiscal austerity leading to persistent economic and financial fragility—and wrecked public finances purely as a consequence of ill-guided monetary dominance. Symmetry of mindset is the key. In case of a large economy that cannot perpetually freeload on external growth stimuli, the true demand management quest is for a sound and balanced macro policy mix featuring the central bank and treasury applying their policy tools and balance sheets in unison.

The fears expressed by Otmar Issing and Jens Weidmann assume that the ECB is meeting its price stability mandate while the economy is operating at full capacity. It also presumes that, at least under such conditions, the ECB's monetary policy stance geared at maintaining price stability would automatically provide the optimal noninflationary budgetary contribution, which could not be boosted, especially not in ways that involve public debt instruments, without conflicting with optimal monetary policy and without doing harm to the central bank's reputation and the wider economy. ${ }^{24}$

In an economy that is operating vastly below its potential, at a near-zero inflation rate, and in the context of an impaired banking system, the fear that any deliberate increase in the central bank's

\footnotetext{
${ }^{23}$ In a speech titled "Who calls the shots? The problem of fiscal dominance," Weidmann (2013b) observed, apparently with some pride, that "we central bankers are indeed obsessed with fiscal policy-and German ones quite probably somewhat more so than those of different nationality." Weidmann then went on to explain that:

Public debt and inflation are related on account of monetary policy's power to accommodate high levels of public debt. Thus, the higher public debt becomes, the greater the pressure that can be put upon monetary policy to respond accordingly. Suddenly it might be fiscal policy that calls the shots-monetary policy no longer follows the objective of price stability, but rather the concerns of fiscal policy. A state of fiscal dominance has been reached. Technically, fiscal dominance refers to a regime where monetary policy ensures the solvency of the government. The traditional roles are reversed: monetary policy stabilizes real government debt while inflation is determined by the needs of fiscal policy.
}

24 The ECB states in its 2013 Annual Report that "(noninflationary) financial resources are by definition limited in practice"... "The only way of ensuring the availability of the necessary and sufficient financial resources for delivering price stability in all circumstances is to preserve the financial strength of the central bank in the long run. This helps eventually to entrench expectations among both the general public and financial market participants that the central bank will not be unduly constrained in the pursuit of its price stability objective by concerns about financial resources" (ECB 2014, Annual Report 2013, 41). 
balance sheet — whether or not it involves the purchase of public debt securities - would substantially risk hyperinflation or other significant adverse consequences is extremely implausible and can only be attributed to popular superstition (or the wish to uphold popular superstition). In fact, the very monetary thought underlying the ECB's (and earlier the Bundesbank's) monetary policies would seem to urgently call for a deliberate expansion of the central bank's balance sheet. ${ }^{25}$ Moreover, in an environment of a dysfunctional financial system, additional liquidity provision may be called for to simply compensate for existing systemic malfunctioning. There may even be scope for the central bank to act as a substitute provider/facilitator of finance by bypassing the undercapitalized and dysfunctional banking system that is the conduit of its policies under normal circumstances (when central bank liquidity is provided purely passively and in a supposedly market-neutral way).

Seigniorage will normally tend to rise in line with the central bank's balance sheet expansion. There are no legal constraints on the ECB's "monetization" of private assets (other than not deliberately taking losses on them on behalf of the government), which once again highlights the artificial nature of the constraints put in place regarding public debt. In practice, those constraints boil down to whether the ECB's open market purchases of public debts are deliberately designed to facilitate fiscal transfers, provide funding relief, and/or distort price formation in the primary markets. Put differently, the ECB will aim at designing any open market purchases in ways that avoid any such suspicions.

The emergency liquidity provision and expansion of the Eurosystem's balance sheet since August 2007 (to be discussed in more detail in section 5, below) was largely based on the purchase of private assets (with public debt merely serving as collateral securing central bank loans to the banks). Unsurprisingly the system's income has also increased.

In December 2010, the ECB decided to increase its subscribed capital by $€ 5$ billion (from $€ 5.8$ billion to $€ 10.8$ billion), declaring in its 2010 Annual Report: "The capital increase was deemed appropriate in view of increased volatility in foreign exchange rates, interest rates, and gold prices, as well as in view of the ECB's exposure to credit risk" (ECB 2011, Annual Report 2010, 210). The increase in the ECB's capital, undertaken in three installments, also enabled an

\footnotetext{
${ }^{25}$ For a blunt monetarist critique, see Hetzel $(2013,15)$ : "Most important, the ECB needs to start by recognizing that Europe's problems are more than structural. It needs to stop using monetary policy as a lever for achieving structural changes and to end its contractionary policy."
} 
increase in its provisions, which are capped at the level of its capital. These measures reduced the ECB's net profit in the years 2010-12 accordingly (to below $€ 1$ billion) ${ }^{26}$ In 2013 its profit was $€ 1.4$ billion and its capital $€ 7.7$ billion. Including its provisions and revaluation account (booking unrealized gains and losses on its assets), the total equity capital was $€ 29$ billion in that year. For the Eurosystem as a whole, capital and reserves increased from €54 in 1999 to $€ 92$ in 2013. Including revaluation accounts the system's overall equity capital position went up from $€ 114$ billion in 1999 to $€ 354$ billion in 2013.

The increase in central bank equity capital and provisions in the euro area since 2008 may be explained in terms of heightened risks of potential losses identified on the Eurosystem's balance sheet. Enlarged loss provisions, by reducing the risk of ex post recapitalization needs, also serve to protect their financial independence. Alternatively, the measures may be interpreted as preventing rising profit distributions to national treasuries, keeping up the pressure for fiscal consolidation. ${ }^{27}$ The principle of financial independence grants central bankers scope for discretion. By comparison, the U.S. Federal Reserve transferred a profit of close to $\$ 100$ billion to the U.S. Treasury last year, roughly equivalent to 20 percent of last year's federal budget deficit. But then, the Federal Reserve does have a federal treasury partner.

In summary, the peculiar vision of central banking underlying the Maastricht Treaty and the fact that Europe's monetary union is not a fiscal union create peculiar constraints on the ECB's discretion over its own balance sheet. The ECB's actual and potential recourse to nonstandard monetary policy measures applied to deliberately steering its own balance sheet has been challenged in the courts on the grounds that its measures fall into the domain of economic policy, constitute monetary financing, and/or may involve cross-border fiscal transfers. The ECB's vulnerability to legal challenges probably helps explaining the bank's insistence on the principle of financial independence and obsessive anxieties about the monetary financing prohibition.

It is therefore clear that the truly abnormal monetary-fiscal policy divorce at the heart of Europe's currency union regime design has some highly detrimental consequences. At the

\footnotetext{
${ }^{26}$ Due to significant write-downs the ECB suffered losses in 2003 and 2004. It then booked zero profits in the subsequent three years. Its profits surged in 2008 and reached $€ 2.3$ billion in 2009. Note that the ECB's effective capital increase was only $€ 3.5$ billion as only the euro-area NCBs have to pay up their capital subscriptions. ${ }^{27}$ For instance, the Bundesbank greatly boosted its provisions in 2010, 2011, and 2012, containing its profit transfers accordingly.
} 
center of the regime stands a peculiarly streamlined ("narrow") federal central bank, focused on little else but monetary policy. Granted a hegemonic macro policy position and a mandate that prioritizes price stability, the ECB is presiding over a central banking system that includes national central banks with broader - though diverse - responsibilities in the financial stability domain. In particular, national central banks have maintained their natural position as lenders of last resort to financial institutions within their respective national policy domain, a responsibility that is traditionally backstopped by the respective national finance ministry. The national finance ministries, however, got effectively cut off from their own natural emergency liquidity backstop - their national central bank - with no federal supplement being put in place in its stead and no federal fiscal capacity either.

Instead of creating a stronghold of monetary and economic stability, this peculiar divorce of monetary and fiscal powers in Europe's currency union is a precarious outcome for all parties concerned - in fact, it is the overriding source of systemic vulnerability in the euro area and ultimate root of the "doom loop" (Goodhart 1998; Bibow 2013d). National treasuries have notionally retained fiscal policy authority, but lacking a central bank partner they have lost effective control over national fiscal affairs, just as NCBs have lost control over national monetary affairs. Yet the national authorities are supposed to assure the viability of their respective national banking systems as these evolve and become more integrated and panEuropean. If this does not sound like a recipe for disaster, what does?

Given that the constituent parts of the system are individually extremely vulnerable, the ECB is well-advised to try to preempt localized liquidity challenges from turning into broader solvency threats. From the beginning of financial market stresses in August 2007, the ECB was forced to be creative with regard to its market liquidity management tools of monetary control. Over time, as the economy continued to deteriorate due to a persistently inadequate macro policy mix, certain treaty provisions have come to hinder and constrain the ECB's monetary policy conduct in important ways - prompting political conflicts, as well as legal challenges and uncertainties along the way.

So the fallacies and illusions regarding the nature of central banking that inspired the Maastricht Treaty have come home to roost. And ultimate control over the euro's fate has come to rest with the German triangle of power, residing in: Berlin (government), Frankfurt (Bundesbank), and 
Karlsruhe (GCC). While the Bundesbank and GCC may have seen their standing slip in the course of developments, the German government is ruling supreme. If Germany's euro partners thought that the euro would permanently overcome Germany's monetary hegemony over Europe, they were proved wrong. The ECJ's (2015) recent opinion on OMT has shed some important light on some critical matters, but legal uncertainties and related challenges remain.

This completes the institutional and legal background to our investigation of the ECB's scope for policy action under crisis conditions. The next section reviews the ECB's role in financial stability policy prior to the crisis (i.e., crisis prevention), whereas the subsequent section investigates how the ECB has actually used its leeway for action under the constraints identified in this section.

\section{THE ECB'S ROLE IN FINANCIAL STABILITY POLICY PRIOR TO THE CRISIS}

Conceived as a narrow central bank with an exclusive and supposedly unchallengeable authority in monetary policy, the Maastricht Treaty only granted the ECB an auxiliary role in financial stability policy. Among the ECB's "basic tasks" laid down in TFEU Article 127 features the duty to "promote the smooth operation of payment systems." Regarding financial stability policy more broadly, the ECB was only assigned a supportive role as the same Article 127 merely asks that "the ESCB shall contribute to the smooth conduct of policies pursued by the competent authorities relating to the prudential supervision of credit institutions and the stability of the financial system"- adding however in the final paragraph that: "the Council, acting by means of regulations in accordance with a special legislative procedure, may unanimously, and after consulting the European Parliament and the European Central Bank, confer specific tasks upon the European Central Bank concerning policies relating to the prudential supervision of credit institutions and other financial institutions with the exception of insurance undertakings."

In addition, the ECB is supposed to be consulted by the relevant union and national authorities and may also submit (unsolicited) opinions to them "on matters in its field of competence," which the ECB has customarily interpreted very broadly (regarding both financial system 
matters and economic policymaking in general). Apart from dedicated sections in its Annual Reports and occasional reporting on the subject in its Monthly Bulletin, the ECB's regular publications also include semi-annual Financial Stability Reports as well as an annual report on (the state of) Financial Integration in Europe, for instance.

The latter publication makes it clear that the ECB believes that it has an active role to play in fostering financial integration of the economic area under its monetary control, distinguishing "between four types of activity through which [the Eurosystem] contributes to the enhancement of financial integration: (i) advising on the legislative and regulatory framework for the financial system and direct rule-making; (ii) acting as a catalyst for private sector activities by facilitating collective action; (iii) enhancing knowledge, raising awareness, and monitoring the state of European financial integration; and (iv) providing central bank services that also foster European financial integration" (ECB 2013, Financial Integration, 49). While the first three types of activities may be understood as being part of the ECB's auxiliary role in financial stability policy, the forth one of fostering European financial integration also relates to its basic task of promoting the smooth operation of the payment system, specifically to the provision of certain services by the ECB regarding the large-value payment infrastructure known as TARGET2.

In this regard, the ECB holds the view that "financial market integration needs to be complemented and supported by the integration of the underlying market infrastructures. The provision of central bank services is another way in which the Eurosystem seeks to promote financial integration in this area. Although the main purpose of such services is the pursuit of the Eurosystem's basic central banking tasks, the Eurosystem pays close attention to ensuring that such services, where possible, are specified in such a way that they are also conducive to supporting the financial integration process" (ECB 2014, Financial Integration, 60-61).

In fact, the ECB has interpreted its basic payment system task as going beyond a general oversight responsibility. It has also carved out an operational role for itself in this area that centers on the TARGET2 large-value payment infrastructure, but also includes securities clearing and settlement systems and collateral management: 
The Eurosystem has the statutory task of promoting the smooth operation of payment systems. Payment systems and securities clearing and settlement systems are fundamental infrastructures that are necessary for the proper functioning of market economies. They are indispensable for the efficient flow of payments for goods, services and financial assets, and their smooth functioning is crucial for the implementation of a central bank's monetary policy and for maintaining the stability of and confidence in the currency, the financial system and the economy in general. For the performance of this task, the Eurosystem applies three approaches: it takes on an operational role, conducts oversight activities and acts as a catalyst. (ECB 2013, Annual Report 2012, 96)

The rationale the ECB provides for operating TARGET2 highlights both safety and levelplaying-field concerns:

With the creation of TARGET2, the Eurosystem made a crucial contribution to European financial integration. Being the first market infrastructure completely integrated and harmonised at the European level, TARGET2 has eliminated the fragmented situation that previously existed in the management of central bank liquidity and the real-time settlement of euro payments. The move to a single platform represented a significant step towards a more efficient, competitive, safe and fully integrated European payments landscape, offering all market participants equal conditions and services regardless of their location. The harmonised service level of TARGET2, offered with a single price structure, ensures a level playing field for all participants across Europe. TARGET2 also provides a harmonised set of cash settlement services in central bank money for all kinds of ancillary systems, such as retail payment systems, money market systems, clearing houses and securities settlement systems. The main advantage for ancillary systems is that they are able to settle their cash positions in TARGET2 via a standardised technical interface and standardized settlement procedures, thus allowing a substantial harmonisation of business practices. (ECB 2013, Financial Integration, 61)

Note that the ECB places great emphasis on the need for a level playing field. Providing a level playing field for all users of the euro payment system is indeed crucial from both single-market and single-currency perspectives. A deficient payments infrastructure can potentially stand in the way of establishing uniform monetary and financial conditions across the currency union. The euro currency exists largely as mere digits in computer systems storing account information and payment streams. By linking up the various national payment systems across the area through a single shared platform, the TARGET2 infrastructure supports the ECB's money market operations and banks' liquidity management. In this way, ultimate settlement of euro payments takes place in central bank money on the balance sheets of the central banks that make up the Eurosystem. In terms of total value, over 90 percent of euro-denominated large-value payments are executed via TARGET2. In that sense TARGET2 is the backbone of the euro. Breakdown of TARGET2 would sever the connections between the parts of the system and 
undermine the functioning of the single currency and single area-wide monetary policy (PadoaSchioppa 2004). Apparently the ECB prefers not to rely on third-party providers of operational services, which it could potentially outsource while exercising oversight only. This may be a wise decision. Also because early indications of emerging financial market stresses may be gleaned from payment-system data accessible to the Eurosystem as operator only.

Turning now to the ECB's (originally) auxiliary role in financial stability policy more generally, it must be said that, as far as the early years were concerned, speaking of a financial stability policy for the euro area amounts to bestowing an honorable title to something of rather limited substance. Given that the single market project preceded the euro by about a decade, the lack of a financial stability policy proper was a truly remarkable situation. Apparently Europe’s policymakers were under the illusion that deep market integration would be safe and sound without any parallel move toward equally deep policy integration. A common competition authority implementing EU competition policy had already been in place. By contrast, in the domain of financial stability policy, featuring financial regulation and supervision as well as financial crisis management and resolution, financial market liberalization created a dangerous vacuum. Europe set out to liberalize and integrate markets without putting in place proper common policies and institutions. As a result, the EU and euro area were ill-prepared institutionally when crisis struck in 2007, as financial stability policy had remained a patchwork of national policies and union initiatives for cooperation even as intra-area interdependencies and systemic interlinkages — and hence the potential for area-wide contagion — had been surging under the euro.

In particular, financial supervision continued to be undertaken by the respective national authorities, including diverse roles for the national central banks (as discussed in section 2, above). Initially (minimal) EU-wide cooperation among bank supervisors operated mainly through the ESCB's Banking Supervision Committee (BSC), based in Frankfurt, as the body taking care of the ECB's auxiliary role in financial stability policy. Forces then prevailed favoring separate financial service agencies and control through non-central bank supervisors, and a new Committee of European Banking Supervisors (CEBS) was established in 2004 in London as part of the Lamfulussy framework. Extending the Lamfalussy framework to the EU banking sector (formally effective since March 2005), the aim was to facilitate the pursuit of supervisory convergence and to promote progress in supervisory cooperation and information 
sharing. In particular, the CEBS was "mandated to develop common standards, guidelines, and interpretive recommendations for the practical performance of supervisory tasks on a day-to-day basis with a view to identifying and gradually converging towards best practice" (ECB, Financial Integration in Europe, March 2007).

As far as preparations in the area of financial crisis management were concerned, the ECB observed in its December 2006 Financial Stability Review that the focus of cooperation between the responsible national authorities was on exchanging information and securing consistency of national policy actions:

\begin{abstract}
The EU's financial stability framework is largely based on the exercise of the statutory responsibilities of central banks, financial supervisors and finance ministries. The enhancements of the specific arrangements for dealing with potential crisis situations have focused on the coordination and wider cooperation processes, both between the different sets of authorities and across Member States. The overall objective of such enhancements is to support the effectiveness of the performance of financial stability tasks in the single financial market by facilitating the exchange of information and the consistency of potential policy actions between the responsible authorities. (ECB 2006a, 165).
\end{abstract}

The introduction of the euro had at least encouraged a review of existing arrangements for financial stability at the EU level. In 2000 and 2001, the Economic Financial Committee issued two sets of recommendations and the authorities signed on to a number of related Memoranda of Understanding on cooperation in crisis situations (see Economic and Financial Committee 2000, 2001, Memorandum of Understanding 2003, 2005). In addition, financial crisis simulation exercises were conducted starting in 2005. In December 2006, on the eve of the financial crises that were going to pose existential challenges to the authorities for years to come, the Eurosystem declared itself fit and ready to handle financial crises as far as its own operational procedures were concerned, including "procedures for the conduct of monetary policy operations, the oversight of payments systems also considering potential consequences for the operation of market infrastructures, and the safeguarding of financial stability ... [and also] regarding the provision of emergency liquidity assistance by the individual Eurosystem NCBs" (ECB 2006, 172). 
Revisiting the ECB's Financial Stability Reviews published in the years prior to the crisis, a number of issues and themes stand out. First among them is the ECB's preoccupation with global (rather than regional) financial imbalances and the risks their abrupt unraveling were perceived to pose to the euro area. The theme of global imbalances features also prominently in other ECB publications and in speeches given by their representatives at the time. The common tenor is that irresponsible policies in the rest of the world were to blame for those global financial imbalances in which the euro area itself was playing no part - as it was successfully keeping its own house in order all along (see Bibow and Terzi 2007). A related theme highlighted an identified global "search for yield" among financial market players. It is quite clear that the ECB had little idea that the euro area's globally active banks were at the forefront of the search for yield and played an active role in global (and regional) imbalances as well.

The December 2006 Financial Stability Review shows some surprise about the fact that "longterm interest rates and credit spreads have been remarkably unperturbed by the shift to less accommodating monetary policies in the G3 economies" (ECB 2006, 11). External positions of the new EU member states in Central and Eastern Europe were judged as not "obviously excessive" (27). Concerns regarding the spread of credit-risk transfer instruments were judged to relate to hedge funds rather than banks, as the latter had advanced their risk management techniques, in the ECB's view. As far as the euro area itself was concerned, the report identified releveraging both on the part of the corporate sector (related to the M\&A boom) and the household sector (related to increases in house prices) as potential risks. Referring to disparities across individual member states, the report even states that "there are continuing concerns regarding balance sheet vulnerabilities in countries where debt ratios are well above the euro area average, especially those in which debt is predominantly financed at floating interest rates" (13). Yet the ECB's assessments sounded anything but alarmed. Moreover, as banks were judged to be in healthy shape and as having managed their exposures to property markets carefully, it was found that in any property-market downturn "euro area households would probably have to bear the brunt of any property price reversal" (13). The ECB's overall verdict thus reads: "With the euro area financial system in a generally healthy condition and the economic outlook remaining relatively favorable, the most likely prospect is that financial system stability will be maintained in the period ahead" (ECB 2006a, 9). These themes and the 
ECB's overall verdict were essentially repeated in the Financial Stability Report of June 2007, the final one before the outbreak of acute market turmoil.

In retrospect, the ECB's most serious oversight and misjudgment concerned the emergence of vast intra-area divergences and the related buildup of financial imbalances. The ECB assessed inflation differentials in a monetary union in 2005, but found that euro-area developments were comparable to the U.S. experience and not really worrisome. The ECB did not see any connection between inflation differentials and divergent unit labor cost and competitiveness trends (see figure 4), denied that destabilizing systemic forces might be at play that would see the buildup of fragility, but instead ventured that the "competitiveness ('real exchange rate') channel, although slow to build up, eventually becomes the dominating adjustment factor" (ECB 2005a, Bulletin, 77).

It is true, in the presence of asymmetric shocks national unit labor cost trends can act as an adjustment factor. By inference, in the absence of asymmetric shocks affecting competitiveness positions, it is vital to keep national unit labor cost trends aligned with the common inflation rate-namely to avoid such divergences from becoming quasi-asymmetric shocks that will ultimately undermine the currency union (Bibow 2005, 2006b, 2007a,b; Flassbeck 2007). The ECB misdiagnosed the situation thoroughly and failed to appreciate the related symptoms of fragility emerging from the euro area's financial system. ${ }^{28}$ Inevitably euro partners at the receiving end of Germany's competitiveness crusade through wage repression would see their external indebtedness and balance sheet vulnerabilities explode in the process. Crisis policies would subsequently force these countries into "internal devaluation" to restore their lost competitiveness - with devastating consequences.

\footnotetext{
${ }^{28}$ The ECB could argue that it merely followed the grossly negligent conduct of the political authorities who, prior to the global crisis, had denied any responsibility for global imbalances in view of the fact that the euro currency union was externally balanced overall. It was a widely-held misperception that the euro had made regional imbalances irrelevant. Interviewing German Chancellor Angela Merkel at the time of the G20 summit in Seoul in November 2010, Barber, Peel, and Wiesmann (2010) quote Mrs. Merkel as even suggesting that in view of the European "single market" the whole European Union should be treated as a unity, leaving the calculation of trade imbalances on a country-by-country basis as "not meaningful." If ECB president Jean-Claude Trichet was concerned about divergences, he seemed to even applaud Germany's wage-underbidding strategy, observing that: "Within a monetary union with increased price and cost comparability it is of paramount importance that firms remain competitive by controlling domestic cost developments as captured by, for example, unit labour costs. This is exemplarily illustrated in the case of Germany which had lost competitiveness due to reunification, and which embarked on a catching up exercise between 1999 and 2005, witnessing only limited cumulated unit labour cost increases of $2.6 \%$ compared to a euro area average of $11.2 \%$. This significant improvement of the German economy's cost competitiveness is one of the explanations for its strong export performance" (Trichet 2006).
} 


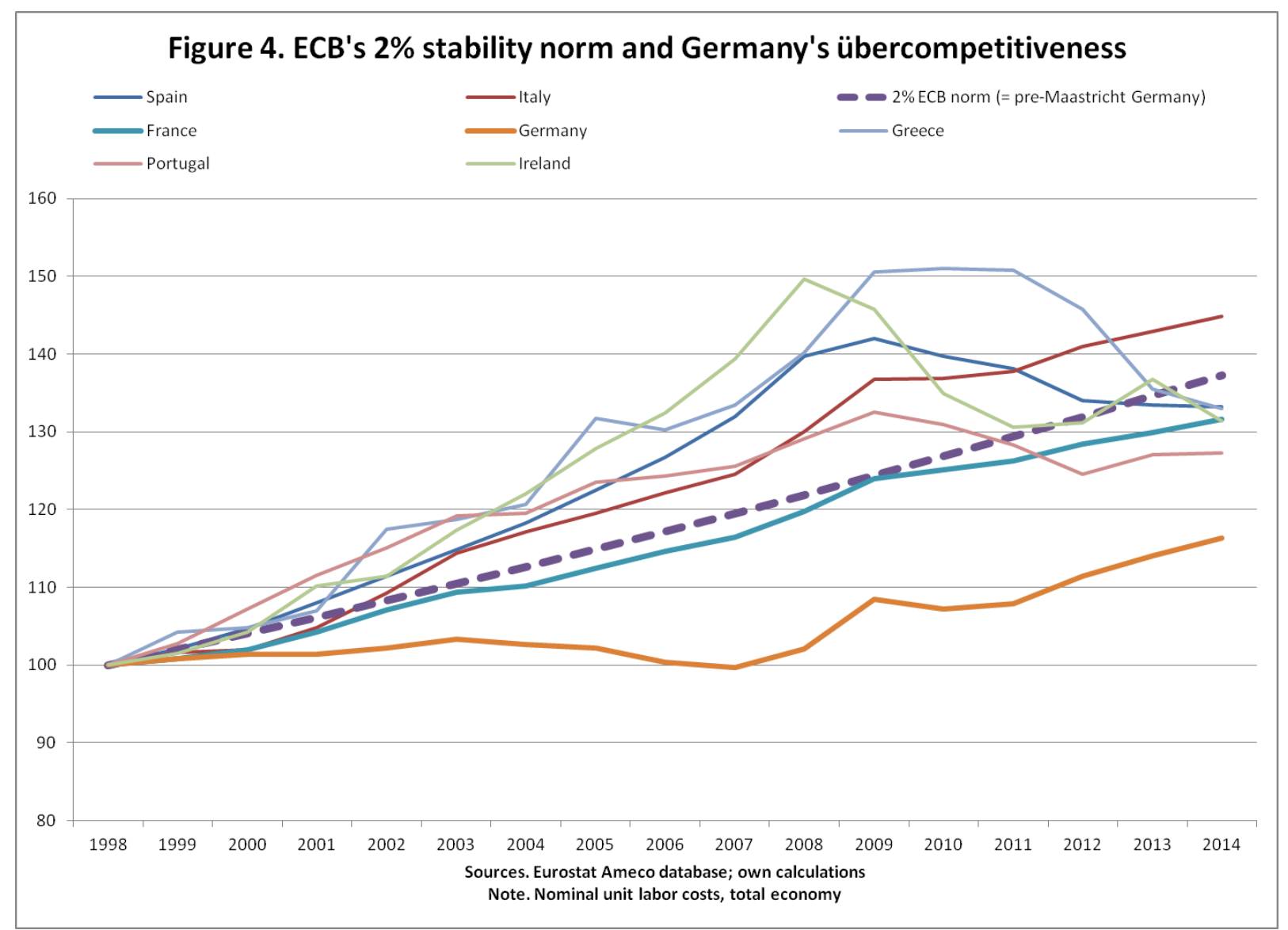

By 2014, the euro crisis countries had converged back to the currency union's price stability trajectory established by the ECB in 1999, but to fully restore their competitiveness vis-à-vis Germany that will not do. Instead, they will have to converge to the new, lower norm set by Germany in denial of the ECB's stability norm. With nominal unit labor costs flat in Germany for the euro's first decade, Germany's partners, including France which until 2009 stayed meticulously close to the ECB's stability norm, are forced into outright deflation to achieve the required internal devaluation (of approximately 15-20 percent). This collective endeavor is destined to push the currency union as a whole towards outright deflation. Needless to say it is rather ironic that Germany should export its own historical 2 percent stability norm to Europe only to then renege on its euro commitment - causing deflation and depression instead of price stability and growth (Bibow 2012a, 2013c).

There is another irony here regarding the ECB's (pseudo) monetarist heritage. Designed under the aegis of Otmar Issing, who was especially dedicated to carry over as much as possible of the 
Bundesbank's stability-oriented legacies to its euro successor, the ECB's monetary policy strategy has featured a "reference value" for M3. Contrary to appearances, the Bundesbank never actually exercised any proper monetarist monetary control. The Bundesbank's resort to monetary aggregates in pre-euro times was purely opportunistic. It is not clear that it was meant to be anything more than that for the ECB. Originally dubbed the "monetary pillar" of its twopillar strategy, the reference value for M3 has officially served the ECB as a benchmark in assessing risks to price stability arising at the monetary front.

The ECB's peculiar M3 mantra was met with widespread criticisms from international ECB watchers. So Otmar Issing offered an additional argument in support of the monetary pillar related to financial stability, stressing its supposed usefulness as an indicator or early warning mechanism of potential financial stability threats. In the context of the "lean versus clean" debate prior to the global financial crisis, Mr. Issing alleged superiority of the ECB's approach and monetary policy strategy featuring the $\mathrm{M} 3$ reference value as a supposed strong point (see ECB 2005a, for instance). Even after Mr. Issing's departure the ECB has continued to make the same case in post-GFC times (see ECB 2012, Annual Report of 2011, for instance). 


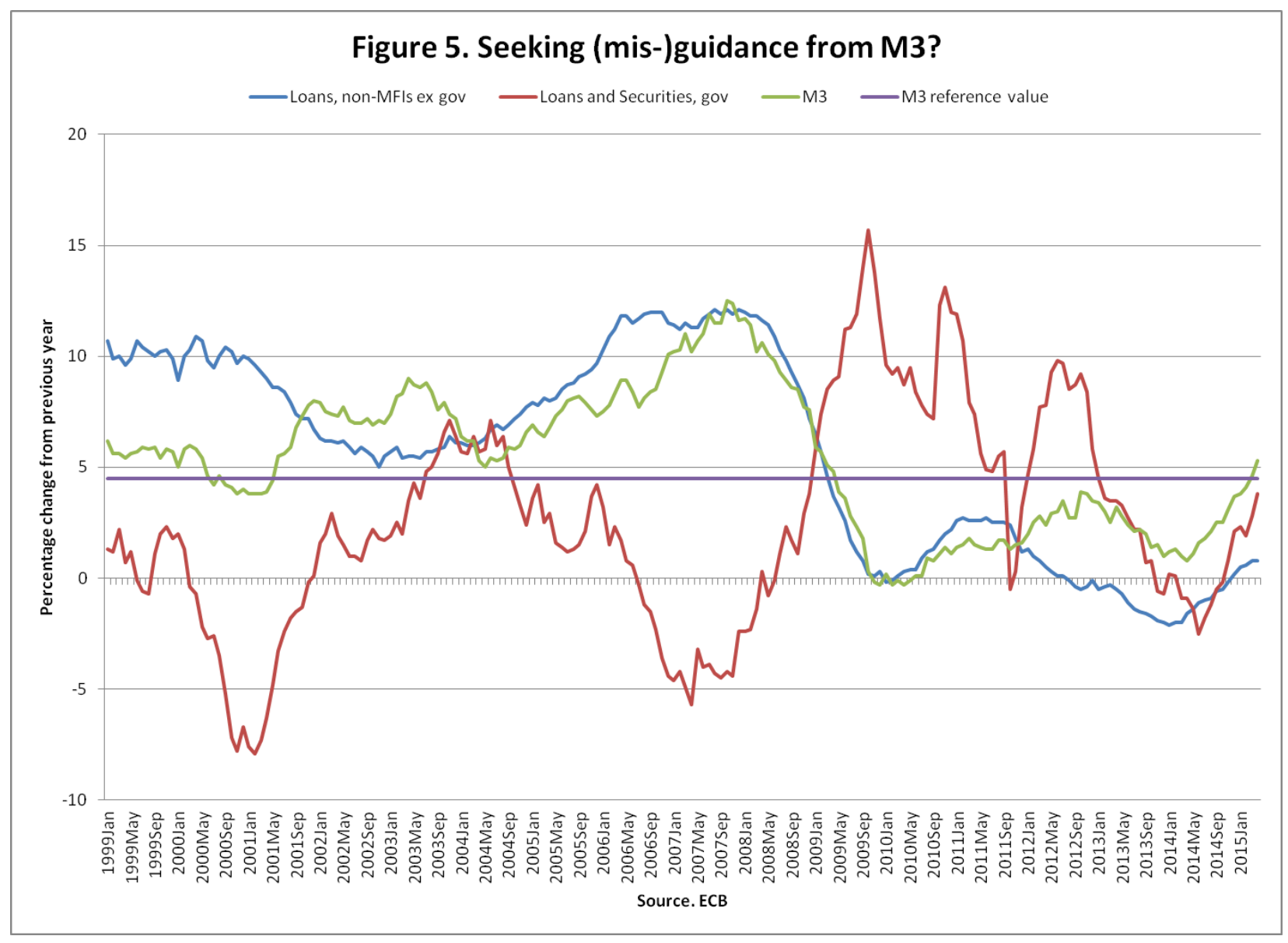

Visual inspection of the evolution of M3 (against its reference value benchmark) and loans to non-MFIs since 1999 leaves one in considerable bafflement as to the supposed substance behind these assertions. What kind of early warnings did the ECB glean from M3, really? What good use has the ECB made of M3, one wonders? If anything, the evolution of M3 would seem to underline the ECB's outstanding failure to play any constructive role in pre-crisis euro-area financial stability policy.

In conclusion, it seems fair to say that the ECB - while having been part of the international "beware-of-search-for-yield" chorus of financial authorities who had publically declared since the mid-2000s that international liquidity seemed ample, volatility subdued, asset prices elevated, and risk spreads compressed - was caught wholly off guard concerning the calamitous exposures and imbalances that had built up inside the currency union under its stewardship. ${ }^{29}$

${ }^{29}$ Remarkably, Jean-Claude Trichet (2009) declared that "turmoil was sudden but not unexpected." 
Imbalances owed primarily to Germany's beggar-thy-neighbor wage repression strategy on the one hand, and to the adventurous explorations of euro-area banks beyond their respective national borders (both within the region and globally) on the other. Granted, when stresses started to erupt in 2007, the European authorities increased their efforts to strengthen financial stability arrangements at the last minute. ${ }^{30}$ But, as previously, these efforts remained restricted to attempts at coordination of national policies and did not include any proper common safeguards or backstops - an approach which was to prove grossly inadequate in due course.

It was going to take the EU/euro area many more years (of crisis and despair) until a more serious approach to financial stability policy was finally adopted under the "banking union" title in 2012. In the course of the crisis - which started to engulf the euro area in the summer of 2007- the ECB's role in financial stability policy has expanded significantly to include responsibility for the prudential supervision of the major banking groups in the euro area, as well as important macro-prudential responsibilities. The next section will scrutinize the ECB's crisis management activities since the start of acute stresses in August 2007 until the end of 2014. We will critically assess the banking union project and the ECB's evolving role in financial stability policy in the subsequent section.

\section{ECB AS CRISIS MANAGER: AUGUST 2007-2014}

At the heart of the central bank's role as crisis manager is "lending of last resort," (LOLR) lending when no one else is willing and able to do so. Narrowly defined, the LOLR function focuses on providing emergency liquidity to specific banks that are solvent but temporarily illiquid. Since containment of market stress and prevention of contagion and market disruption are the true concern and objective, lending of last resort more broadly may extend to nonbank financial institutions and markets in general. The ability to provide emergency ability leaves the central bank at the forefront of stemming (potentially) systemic events in the financial system.

\footnotetext{
30 "In May 2008 the ECOFIN Council updated the EU roadmap on strengthening financial stability arrangements adopted in October 2007. In accordance with this roadmap, the Memorandum of Understanding (MoU) on crossborder financial stability among EU supervisory authorities, finance ministries and central banks entered into force on 1 June 2008." (ECB 2009, Annual Report 2008, 152).
} 
Typically this involves accepting collateral that is depressed in price under crisis conditions but considered likely to recover in price as market conditions return to normal. ${ }^{31}$

LOLR overlaps with monetary policy in the sense that the latter is mainly about setting the price of central bank money while the former is mainly about flexibly meeting idiosyncratic surges in liquidity preference under crisis conditions. Adjusting the monetary stance becomes part of crisis management if the crisis in confidence and stressed financial market conditions that give rise to LOLR threaten to negatively impact the economy - also considering that failure to stabilize economic activity and foster recovery can, in turn, give rise to bank solvency and hence new liquidity problems. In principle, a central bank can act as LOLR as long as the monetary instruments it issues are generally accepted as money or: "liquidity par excellence" (Keynes 1936). ${ }^{32}$ Any practical limits thus largely depend on public perceptions, perceptions of solidity - ultimately perceptions of the solidity of the state whose money the central bank issues and who is the ultimate solvency backstop of both the central bank itself and of the banking (and payment) system as a whole. Legal limitations, wise or unwise, are another matter. Section 3, above, investigated the special institutional and functional constraints that may affect the ECB in its role as crisis manager.

Much of the ECB's crisis management in the period from August 9, 2007 until the end of 2014 may be thought of as an extension, along a number of dimensions, of its usual monetary policy implementation of liquidity provision to the euro-area banking system(s). The core principles are straight forward: the ECB sets the price of short-term central bank liquidity by announcing its policy rates, and then meets the demand for liquidity arising at the stated price against collateral of certain specified minimum quality in dealing with certain accepted counterparties. ${ }^{33}$

\footnotetext{
${ }^{31}$ Bagehot ([1873] 1999) is generally credited for providing the rationale for and blueprint of LOLR. On the LOLR function see Freixas et al. (1999), Goodhart (1999), Goodhart and Illing (2002), and Tucker (2014a, b), for instance. Contributors to the pre-crisis discussion on the LOLR issue in Europe's currency union include, for instance, Folkerts-Landau (1992), Aglietta (2000), Goodhart (2000), Lastra (2000), Padoa-Schioppa (2000), Prati and Schinasi (1998, 2000), and Schinasi and Teixeira (2006).

${ }^{32}$ Keynes is largely quiet on institutional monetary detail in The General Theory (Bibow 2009b). There is however his humorous remark that: "Unemployment develops, that is to say, because people want the moon;-- men cannot be employed when the object of desire (i.e., money) is something which cannot be produced and the demand for which cannot be readily choked off. There is no remedy but to persuade the public that green cheese is practically the same thing and to have a green cheese factory (i.e., a central bank) under public control" (Keynes 1936, 235).

33 "Once the ECB has set its key interest rates, it implements its monetary policy by allotting the amount of liquidity needed by the banking sector to meet the demand resulting from so-called autonomous factors and to fulfill the reserve requirements" (ECB 2010, Monthly Bulletin October, 61).
} 
There had been some variations in its operating procedure during normal times, specifically its tender procedures when the ECB felt that market expectations of policy changes were running ahead of themselves. But the essential point is that the ECB is a price setter, while the quantity of central bank money is endogenously determined by the evolution of the euro-area banking system(s)'s balance sheet(s) and the public's demand for cash. The only relevant quantitative constraint from the perspective of the system as a whole (and any individual counterparty) is the availability of acceptable collateral, the standards of which are however determined by the ECB itself. If anything, liquidity management under crisis conditions has made these principles even clearer than before. The ECB itself says as much in its 2013 Annual Report:

\begin{abstract}
The fixed rate full allotment tender procedure that has been in place for essentially all refinancing operations since October 2008 implies that the demand for liquidity of euro area banks that are counterparties of the Eurosystem is met in full, provided counterparties can pledge adequate collateral to secure their borrowing. As a result, the size and composition of the Eurosystem's balance sheet is determined, for a large part, by the euro area banking system's aggregate demand for liquidity. (ECB 2014, Annual Report 2013,36)
\end{abstract}

So the key feature of the ECB's operating procedure under crisis conditions has been the full allotment of any liquidity bids at a fixed rate ("fixed rate full allotment" or FRFA), and on the basis of collateral requirements that have seen considerable easing in the course of events. ${ }^{34}$ In this way, the ECB has managed to keep the euro-area banking system(s) afloat even at times of acute and widespread solvency concerns. In fact, Buiter and Rahbari (2012b) argue that de facto the ECB "has provided financial support to manifestly insolvent banks and sovereigns to prevent disorderly defaults of sovereigns and of systemically important banks and to create a window for orderly sovereign debt restructuring and for orderly bank debt restructuring and bank recapitalization instead" (Buiter and Rahbari 2012b, 7).

Before assessing the ECB's evolving emergency liquidity programs designed to passively meet the euro-area banking system(s)'s liquidity needs during repeated bouts of turmoil, convulsion, and fragmentation, it is worthwhile to first pause a moment here and briefly revisit how the single monetary policy was supposed to work according to the Maastricht Treaty script.

\footnotetext{
${ }^{34}$ FRFA does not represent any fundamental break with normal ECB practice of acting as a price setter, while central bank liquidity is endogenous. In normal times the ECB can quite accurately forecast overall liquidity demand and design the quantity part in its tender procedures accordingly. If it gets the quantity wrong, the market interest rate will deviate from the ECB's target rate - and typically prompt FTOs to realign the two.
} 
Essentially, the market economy principles underlying the Maastricht regime held out a vision of a single monetary policy that was neutral with regard to the spatial allocation of resources and activity across the currency union. It would be left to the allocation of credit and finance by banks, other financial intermediaries, and financial markets to determine the allocation of resources and activity across the currency union, with monetary policy merely providing the neutral nominal anchor for establishing financial conditions that are aligned with the (average) macroeconomic requirements of the area as a whole, focused on maintaining price stability in particular. That alone will not earn the single monetary policy its attribute of "singleness." In addition to perfectly matching monetary stance and macroeconomic requirements overall, it is also necessary that financial conditions anchored by the single monetary policy are neutral and uniform across the union in the sense of not favoring one member state or region over another. Anything else would be in conflict with the principles of a competitive market economy and the very idea of a level playing field that already inspired the single market project. What does it require for monetary policy to be in a position to establish monetary and financial conditions that are in this sense neutral and uniform - truly "single"-across the whole currency union?

One requirement is that the integrated financial system is subject to uniform regulations and supervision, which was obviously not fulfilled at the outset. If banks, other financial intermediaries, and/or markets operate under different regulatory regimes and supervisory practices in different member states, competition and prices will likely be distorted. Another requirement relates more specifically to monetary policy. We saw further above that the ECB emphasizes that its role ("basis task") in payment system oversight, including, on its interpretation, the provision of the payment system infrastructure (TARGET2 in particular) and related operational services, is instrumental in establishing a level playing field and fostering financial integration. The issue here is that establishing uniform monetary conditions throughout the currency union presupposes fully integrated money markets and (wholesale) payment systems (including securities clearing and settlement systems and collateral management).

Making the operational target of monetary policy effective in the market and establishing uniform monetary conditions is only the starting point, the anchor of financial conditions, which are however not thereby automatically uniform and neutral across the currency union in the above sense. Far more than that is required. The following quotation from a recent ECB 
Monthly Bulletin highlights the crucial role of the term structure of risk-free interest rates for monetary policy:

\begin{abstract}
Regarding the role of risk-free rates in monetary policy transmission, the first step in this process normally consists of steering very short-term interbank interest rates by means of monetary policy instruments. Moreover, through its monetary policy strategy and communications, the central bank also affects expectations of how it will steer shortterm risk-free rates in the future. Current and expected future short-term risk-free rates are, in turn, a major determinant of the whole term structure of short and longer-term risk-free interest rates. This term structure of risk-free interest rates is therefore a key input into the pricing of other assets that are relevant to the financing conditions of households and corporations, their consumption, production and investment decisions and, finally, price-setting and inflation. For instance, for a given default risk and credit spread of a corporate issuer, a decrease in the risk-free rate of relevant maturity would reduce the firm's market financing costs, improving its ability to finance production and investment, and so on. The term structure of risk-free rates can therefore be seen as the backbone of the wider transmission of the monetary policy stance to a broader range of asset prices and, ultimately, the real economy. (ECB 2014, Monthly Bulletin, July, 66)
\end{abstract}

By implication, establishing financial conditions that are uniform and neutral across the currency union presupposes that asset prices and credit risks are priced of a common term structure of risk-free rates. Contrary to what is suggested in the ECB quote above, interbank interest rates (on interbank loans) are not necessarily risk free at all, especially when unsecured. By market convention — and intrinsically related to the nature of sovereign money—public debt securities are usually the closest thing to being (credit) "risk-free" instruments and hence provide the true backbone of the wider transmission of monetary policy to financial conditions. ${ }^{35}$

It is a great puzzle that the markets for about a decade ignored that the financial instruments that would normally provide such a common term structure of risk-free rates did not actually exist in the euro area, but — by convention - simply treated the public debt securities of the member states as (near) perfect substitutes. This occurred despite the fact that the sovereign issuers had actually lost their monetary sovereignty with the introduction of the euro - and were thus at risk of default (Goodhart 1997, 1998, 2007), and also despite the "no bailout" clause. The result of

\footnotetext{
${ }^{35}$ The ECB's following statement essentially confirms this point: "While government bonds have traditionally been an important element in the transmission process because they serve as a benchmark, or floor, for the pricing of other financial contracts and fixed income securities, they have also emerged as a prime source of collateral in interbank lending over the past few years. As a result, excessive or abrupt changes in the value or availability of these securities can imply a sharp deterioration in banks' funding conditions, with adverse effects on both the supply of bank loans to the real economy and their prices" (ECB 2010, Monthly Bulletin, October, 63).
} 
this market convention was that financial conditions for long appeared to become more and more uniform across the currency union prior to the crisis.

The ECB was criticized for encouraging the pre-crisis compression of sovereign credit spreads among euro-area member states by treating their debts uniformly in its collateral policies (Buiter and Sibert 2006). The point is, however, that an approach other than that could have been criticized as putting private borrowers at either an advantage or disadvantage based purely on their nationality, given that their private credit risk continued to be priced of the debt of their respective national sovereign. A monetary policy can hardly be considered uniform and neutral across a currency union if its effects are conditional on the nationality of the respective borrowers. The supposedly "single" monetary policy would lack "singleness."

And that is of course precisely what has become the stark reality as the euro crisis has unfolded: the euro-area financial system has become deeply dysfunctional and fragmented, and prices and credit crassly distorted as a result (see Pianeselli and Zaghini 2014, and Bologna and Caccavaio 2014 , for instance). ${ }^{36}$ Importantly, price distortions were not simply the consequence of crisis as such, but also due to serious flaws in the euro regime's design. The flaws had remained unnoticed or ignored in the good times, but when the bad times arrived, those flaws hit with a vengeance. It is important to bear this in mind when assessing the ECB's crisis management. The ECB has not only been hindered by its own legal and institutional constraints; systemic flaws in the Maastricht regime in other regards, too, have caused manifold distortions and challenges, which the ECB has at times tried to compensate for by improvisation.

\footnotetext{
${ }^{36}$ Meanwhile, the ECB has changed its policy and now prices sovereign risk according to external ratings, applying differentiated haircuts to collateral based on nationality. As said, this policy may be criticized as amplifying distortions and market fragmentation, which are due to regime design flaws and in utter conflict with the very idea of the single market and single currency.
} 


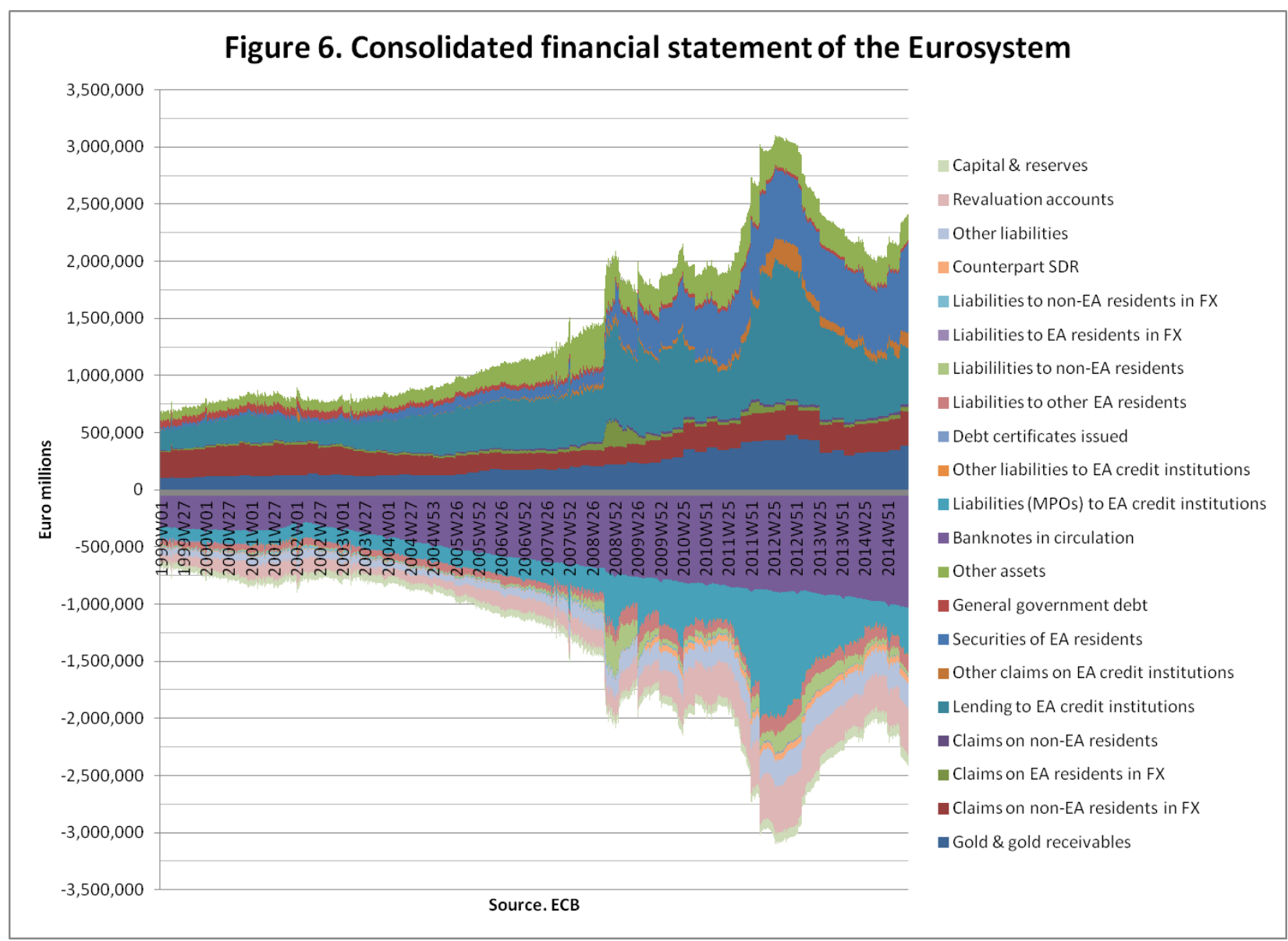

Figure 6 shows the evolution of the consolidated financial statement of the Eurosystem since 1999. (All assets and liabilities are denominated in euro unless stated otherwise.) As can be seen, the system's consolidated balance sheet has grown from just under $€ 700$ billion at its inception to over $€ 2$ trillion by the end of 2014 , with an interim peak of just over $€ 3$ trillion reached in early to mid-2012. Banknote issuance has grown steadily since 2002 to around $€ 1$ trillion today - a significant share of which is actually circulating outside the euro area. On the asset side, gold and gold receivables have greatly increased in value over the period, although standing significantly below their peak value reached in the fall of 2012, with a corresponding increase reflected on the liabilities side under "revaluation accounts." The item with the biggest growth and variability on the asset side has been "lending to euro-area credit institutions," while the corresponding item on the liabilities side has been "liabilities to euroarea credit institutions." This is where the main part of the ECB's monetary policy cum crisis management liquidity action has happened. 


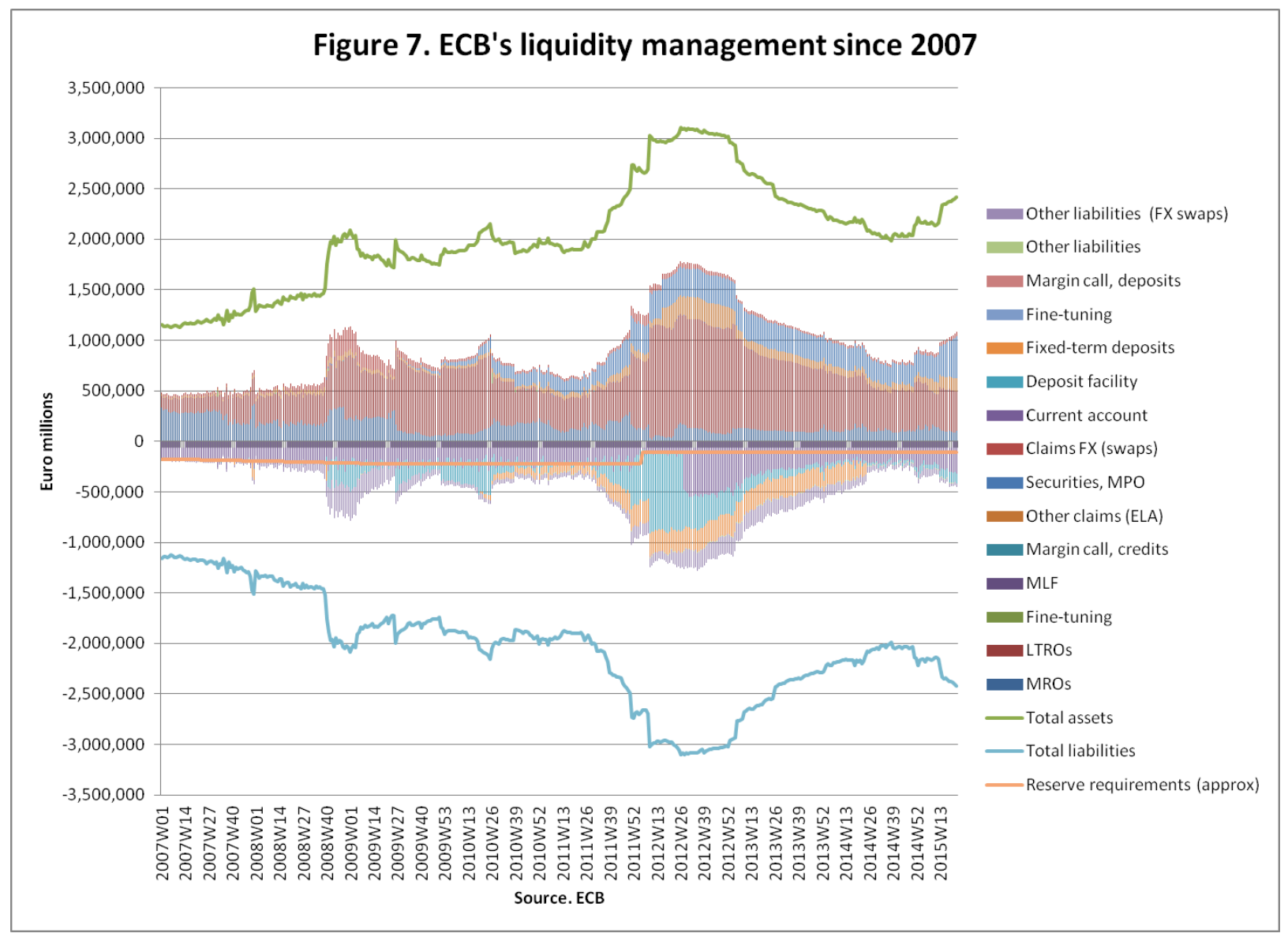

Figure 7 shows a version of the Eurosystem's consolidated balance sheet since 2007 that is both simplified and more detailed, zooming in on those items most closely related to the ECB's crisis management. ${ }^{37}$ A central bank provides central bank liquidity ("prints money") by making loans or buying assets; it retires (or "mops up") central bank liquidity by selling assets or when loans get repaid. Prior to the crisis the ECB met roughly two-thirds of the system's liquidity needs through its weekly "main refinancing operations" (MROs) and the remainder through its monthly "longer-term refinancing operations" (LTROs), originally of a three-month maturity. All along the banks' current account balances very closely corresponded to the level of required reserves; "excess reserves" were nonexistent. ${ }^{38}$ The marginal lending and deposit facilities-

\footnotetext{
${ }^{37}$ We have deliberately excluded the so-called "autonomous" liquidity factors that are not directly controlled by the central bank. As seen above, the banknote issue has grown rather steadily. Central government deposits soared after the Lehman collapse and again in 2012, but have otherwise been a minor liquidity factor overall.

${ }^{38}$ Figure 7 shows the approximate level of required reserves (data for which is only available on a monthly basis). Required reserves started from $€ 100$ billion in 1999 and reached their peak level of just over $€ 220$ billion in early 2009. The reserve ratio was cut in half from 2 percent to 1 percent of the reserve base in early 2012, when the level
} 
providing a usually symmetric interest rate corridor around the ECB's key policy rate, the EONIA target rate anchored through the MROs - were of little significance in terms of volume (with recourse to them usually concentrated towards the end of the reserve maintenance period). Fine-tuning operations (FTOs), too, were infrequent and typically small in volume.

Matters have changed fundamentally since August 2007, in stages. Market stress first arose in euro money markets on August 9, 2007, arising from tensions in some segments of the dollardenominated money market. ${ }^{39}$ As the euro overnight rate soared well above the ECB's policy target rate of 4 percent, the ECB provided additional $€ 95$ billion liquidity through a prompt FTO. In the period until the Lehman Brothers collapse, the ECB's liquidity provision remained steady overall but shifted away from one-week MROs towards three-month LTROs as the ECB provided two supplementary three-month LTROs in August and September of $€ 40$ billion and $€ 75$ billion, respectively, to counter the sharp rise in the three-month EURIBOR rate to a level well above the three-month EONIA swap rate. Also, the ECB switched to "frontloading" its liquidity provision towards the beginning of the reserve maintenance period (to somewhat contain the usual rate spikes towards its end).

In connection with the Federal Reserve's "Term Auction Facility," through which the Federal Reserve System provided collateralized loans to depository institutions to counter the stress in U.S. markets, the Federal Reserve and the ECB entered into a reciprocal currency arrangement in December 2007. The central bank "swap line" enabled the ECB to provide U.S. dollar liquidity to its euro-area bank counterparties to relieve their dollar funding challenges (McCauley and von Peter 2009; McGuire and von Peter 2009). (The foreign currency swap line shows up on both the asset and liability sides of the Eurosystem balance sheet to the extent it was actually drawn upon in the context of two credit operations on December 20 and December 27). Some euro-area banks had become greatly reliant on U.S. wholesale funding markets to finance their foreign adventures into high-risk products, but were then caught lacking sufficient collateral to access the Fed's liquidity facilities. The dollar funding channel through the central bank swap line was also especially vital for smaller euro-area banks without direct Federal Reserve access. The dollar swap line was briefly renewed in January and then again reopened in

of required reserves fell to their current value of just over $€ 100$ billion. Required reserves are remunerated at the rate of what banks pay for loans in the main refinancing operations.

${ }^{39}$ Market stress had built up since June and was, at this stage, focused on subprime-related losses incurred by investment funds and banks, including Germany's IKB and France's BNP Paribas, for instance. 
March 2008. Both the duration and the volume of operations were raised (to 84 days and to a maximum of $\$ 50$ billion). Earlier in February the ECB had also renewed the two additional three-month LTROs and in March it added another three-month operation as well as one with six-month duration.

Remarkably, after hiking interest rates in both March and June 2007 by 25 basis points each, the ECB upheld its tightening bias, which it signaled in its communications, until the summer of 2008. What turned out to be the ECB's final hike only came through on July 2, 2008, almost a full year after market stress had first emerged - to a peak level of 4.25 percent. $^{40}$

During this first phase of market stress the ECB thus acted in what appeared to be a somewhat schizophrenic manner: promptly and flexibly meeting extraordinary liquidity needs arising from banking problems while further tightening its monetary stance. ${ }^{41}$ Unfolding events had brought to the ECB's attention that the U.S. economy, traditionally the global economy's main growth engine, was stalling, and that euro-area banks were facing serious challenges related to exposures to "toxic assets" in the U.S. In addition, the ECB had not failed to notice that euroarea residential property prices were cooling and the corporate bank lending cycle turning as the banks had started to tighten their lending standards. Nonetheless, the ECB remained preoccupied with what it perceived as acute inflation risks while holding surprisingly optimistic views as to the euro area's growth outlook. ${ }^{42}$

\footnotetext{
${ }^{40}$ In fact, the ECB continued to signal its tightening ambitions right up to the collapse of Lehman Brothers. See WSJ, August 23, 2007, "ECB signals rate increase is still likely"; FT.com, September 8, 2007, "ECB still pursuing rate rise policy"; Bloomberg, August 14, 2008, "ECB vows to fight inflation even as economy contracts"; FT.com, September 16, 2008, "ECB reaffirms inflation stance." The ECB referred to its "separation principle": the strict division between monetary policy decisions and their implementation through monetary policy operations. With the U.S. Fed aggressively easing since January 2008 , the euro appreciated strongly during this phase.

${ }^{41}$ I venture that the contrast between the observed inertia in ECB rate setting and the bank's prompt accommodation of changing liquidity demands may be best understood in terms of the responsibilities of its two governing bodies. The rate setting Governing Council is large and unwieldy and operates by consensus. The Executive Board is small and more hierarchical and charged with executing the Council's policy, i.e., making the interest rate target effective in the market. Irwin credits Jean-Claude Trichet for quickly convincing the Executive Board on August 9, 2007, that "there is only one thing we can do, which is to give liquidity" (Irwin 2013, 3). ${ }^{42}$ For instance, Bundesbank president Axel Weber declared in June 2008 that: "For setting the Eurosystem monetary policy stance, however, the outlook on price stability is the magnetic needle of the Governing Council.... The euro area remains on solid fundamentals with regard to real economic growth. This view is underlined by the Eurosystem staff projections published yesterday. And also the outlook on Germany as laid out in the Bundesbank forecast published today supports this assessment" (Weber 2008, 6-7). At the time of Weber's speech, in June 2008 , the euro area was actually stagnating. Weber's proclamation of "solid fundamentals" must be compared to notorious ECB declarations in subsequent years that what was keeping the euro area in stagnation was a lack of fiscal austerity and structural reform. It was only in August 2014, specifically in his Jackson Hole speech, that Mario Draghi (see Draghi 2014b) finally acknowledged the obvious: that insufficient aggregate demand was at
} 
Things took a severe turn for the worse in September 2008, with the bankruptcy of Lehman Brothers on September 16 triggering a new climax of financial market panic and turmoil. The ECB's first rate cut occurred on October 8, 2008 as part of an internationally coordinated policy easing by key central banks (see WSJ 2008, “Central banks cut rates world-wide," October 8). Further cuts followed in November and December that took the key policy rate to 2.5 percent by year end. As stated in the quotation at the beginning of this section, in October the ECB switched from conducting variable rate tenders with a minimum bid rate to "fixed rate full allotment" tender procedures for its MROs, LTROs, and special-term refinancing operations (with a maturity of one maintenance period). Henceforth EONIA would typically stay closer to the rate on the deposit facility rather than the ECB's key policy rate.

On the same occasion the list of eligible collateral was expanded, with the threshold for marketable and nonmarketable assets being lowered to "BBB-," as all rounds of LTROs were rolled-over. The banks' use of the deposit facility soared from close to zero to over $€ 300$ billion between October 2008 and early 2009, while their recourse to the marginal lending facility only briefly reached a peak of $€ 25$ billion in early October, prompting a FTO of that magnitude, but generally stayed below $€ 10$ billion. The ECB narrowed the spread between the standing facilities (the width of its interest rate corridor) to 150 basis points from 200 basis points previously to reduce the costs of the banks' increased liquidity preference, as the banks were effectively borrowing at the higher MRO rate to deposit excess liquidity held for precautionary reasons at the lower deposit rate.

In addition, in October, the swap line with the Federal Reserve became officially "unlimited" and the ECB provided dollar liquidity to euro-area banks through both collateralized repos and FX swaps. Actual volumes surged by over $€ 200$ billion in the fall of 2008 . The ECB also opened a swap line with the Swiss National Bank, which allowed it to provide Swiss franc liquidity to euro-area banks, and entered agreements with some other EU central banks (Denmark, Poland, and Hungary) to provide euro liquidity to them.

least part of the problem - so that more competent demand management would presumably also have to be part of the solution to the euro area's struggles. In 2004, his predecessor, Jean-Claude Trichet, was happy to declare that it was normal for the ECB and the euro area under its stewardship to sit out any stagnation in domestic demand and wait for exports to ignite growth — the old Bundesbank model. See Trichet (2004). 
By the turn of the year there was no denying anymore that the "global financial crisis" was pushing the global economy into deep recession; especially the U.S. and European economies were in freefall. The ECB cut its policy rates further in four steps between January and May 2009 when its key policy rate reached 1 percent. Policy easing certainly occurred at record speed by the ECB's own standard (set previously in the context of the "global slowdown" of the early 2000s), but, compared to other key central banks, the ECB eased its stance more timidly and with more delay.

During the first half of 2009 the volume of liquidity provided by the ECB and the banks' use of the deposit facility generally declined. In May 2009, the ECB launched its first of only a very few tentative liquidity measures that went beyond what has otherwise remained the essential feature of its general approach of crisis management until 2014: to merely passively satisfy the banks' evolving demand for central bank liquidity. As part of what it dubbed its "enhanced credit support approach," the ECB established a program of outright purchases of covered bonds for monetary policy purposes.

The aim of the Covered Bond Purchase Programme (CBPP) was to contribute to the revival of the covered bond market. The ECB announced that it intended to purchase euro-denominated covered bonds in the amount of $€ 60$ billion by the end of June 2010. Nearly half of that total volume was accomplished by the end of 2009 , roughly three-quarters in the secondary market and one-quarter in the primary market. Also in May, the ECB decided to offer three twelvemonth LTROs, the first one of which was settled on June 24. This turned out to be an attractive offer for the banks, and the second half of 2009 therefore started with a sizeable liquidity boost overall (as the twelve-month LTRO only partly "crowded out" some volume of the MROs and shorter LTROs). It is also noteworthy that the ECB included the European Investment Bank among its eligible counterparties at that time.

These measures had some effect, as the global environment was also improving, and so the dollar and Swiss franc swap lines were discontinued in January 2010. Financial conditions in the euro area eased quite significantly, with rates up to one-year maturity effectively pegged at the ECB's tender rate and very short rates staying closer to its lower deposit rate. Interbank lending, securities issuance, and especially covered bond markets revived following the ECB's announcement of support. However, while banks were facing strong incentives to recapitalize 
through the "carry" available on purchasing government bonds (which would later cause some regrets), bank lending to the private sector stalled as banks tightened their lending standards. Nonetheless, the ECB decided that conditions had improved sufficiently to phase out some of its nonstandard measures. The six-month, twelve-month, and supplementary three-month LTROs were all set to be discontinued and variable rate tender procedures to be reintroduced for the regular three-month LTROs in late April-leaving only the MROs and special-term refinancing operations (of a maturity of one maintenance period) under fixed rate full allotment.

Severe market tensions reemerged soon enough. This time the focus of market attack was on Greece, which in the fall of 2009 had revealed that its public finance were in far poorer shape than its official statistics had previously suggested. And so the euro-area authorities came to conveniently view the crisis of Europe's currency union as a "sovereign debt crisis" (PisaniFerry 2014; Legrain 2014; Wolf 2014). In May 2010, the dollar swap line with the Federal Reserve was reactivated and the ECB's Governing Council decided on May 10 to keep all refinancing operations under fixed rate full allotment procedure and conduct an additional sixmonth LTRO. The Governing Council also agreed to launch the "Securities Markets Programme" (SMP). Recourse to the deposit facility peaked at $€ 384$ billion in June. Markets then temporarily calmed somewhat and the volume of the deposit facility declined again to $€ 50$ billion by December as the twelve-month LTROs launched in the previous year matured in July and September.

The ECB's SMP, which by year end attained a volume of $€ 74$ billion, proved to be highly controversial. While the goal of the earlier CBPP, launched in July 2009 and completed in June 2010 at the target volume of $€ 60$ billion, was to revive the covered bonds market (an important source of bank funding), the declared objective of the SMP was to "address the malfunctioning of certain euro area debt securities market segments and to ensure an appropriate monetary policy transmission mechanism" (ECB 2011, Annual Report 2010, 100). At the heart of the controversy about the SMP was the fact that the ECB purchased government bonds, moreover, mainly Greek government bonds at the start. ${ }^{43}$

\footnotetext{
${ }^{43}$ In 2010 the ECB also purchased Irish and Portuguese public debt securities. In 2011 and 2012 purchases focused on Italian and Spanish public debts. The ECB published the details of the Eurosystem's holdings of securities under the SMP in February 2013. See http://www.ecb.europa.eu/press/pr/date/2013/html/pr130221 1.en.html
} 
The ECB embarked on the SMP despite opposition from its two German Governing Council members, Executive Board member Jürgen Stark and Bundesbank president Axel Weber (both of whom resigned in the following year). The ECB faced accusations that its SMP would constitute "monetary financing." This was in spite of the fact that —in contrast to its procedures in buying private debts under the CBPP - the ECB purchased the government bonds only in the secondary market and also fully absorbed the liquidity created thereby through weekly collection of fixed-term deposits from the banks. The fact that the SMP exclusively targeted government bonds of certain nationalities made it highly suspicious. This was also the case since the ECB had to suspend the application of the minimum credit rating threshold in the collateral eligibility requirements for bonds issued or guaranteed by the Greek government (the "waiver"). ${ }^{44}$ A joint EU and IMF "bail-out" program for Greece had been finalized a week earlier. The SMP may be seen as supplementing the rescue package for Greece and the EFSF agreed by governments, focusing on the repair of the monetary policy transmission mechanism. ${ }^{45}$

\footnotetext{
${ }^{44}$ The ECB is unquestionably right that "government bond markets play an essential role in the monetary policy transmission process" (ECB 2011, Annual Report 2010, 18). When a particular national government bond market becomes dysfunctional, problems will spread to other private market segments and banks (as holders and users of government debt as investments and collateral) and borrowers of the same nationality. However, the ECB's justification of the SMP as a monetary policy measure that leaves the monetary stance unchanged and hence poses no inflation risk is partly self-defeating. In particular, full sterilization made the SMP less of a monetary policy measure. According to the ECB, "the increase in liquidity as a result of the bond purchases made in the context of the Securities Markets Programme is fully sterilized by means of specific operations to reabsorb it, as it is not the aim of the programme to inject additional liquidity into the banking system. The prevailing level of liquidity and the money market rates (in other words, the monetary policy stance) are therefore not affected by the programme, which consequently poses no inflationary risks" (ECB 2011, Annual Report 2010, 19). Arguably, instead of only supporting one particular sovereign debtor, adjusting overall monetary stance accordingly (namely by cutting interest rates) would provide a "cleaner" monetary policy measure. That option disappears once short-term rates hit zero. At that point it becomes less controversial that deliberately creating - and not sterilizing — liquidity by whatever means becomes a last-resort (ultima ratio) monetary policy measure to fight deflation. The ECB finally was to reach that point only four years later, in the summer of 2014.

${ }^{45}$ In fact, the ECB's announcement of the SMP on May 10, 2010 was preceded by bouts of market panic and frantic political negotiations. On May 2, 2010, following months of bickering, the Eurogroup finally announced a $€ 110$ billion "bail-out" package for Greece (two-thirds of which were to be provided through coordinated bilateral loans and one-third through IMF assistance). A joint statement of May 7 reads: "in the current crisis, we reaffirm our commitment to ensure the stability, unity and integrity of the euro area. All the institutions of the euro area (Council, Commission, ECB) as well as all euro-area member states agree to use the full range of means available to ensure the stability of the euro area"

(http://www.consilium.europa.eu/uedocs/cms data/docs/pressdata/en/ec/114295.pdf). On May 9, the creation of the European Financial Stability Facility (EFSF) was then announced, a temporary mutual assistance mechanism backed by the euro-area member states. The EFSF, which was initially established as a private-sector organization in Luxembourg, was to be replaced later by the European Stability Mechanism (ESM), which is a treaty-based international organization that is supposed to more permanently fulfill the role as the euro's mutual quasi-fiscal backstop. Remarkably, as Batastin (2015) reports, Alex Weber played a decisive role in the ECB's agreement to
} 
Greece got company from another euro-area member that was "bailed out" later in the same year. The ECB's role in the Irish "bail-out" of November 2010 is highly controversial. For instance, Legrain argues: "Eurozone policymakers, notably ECB President Trichet, outrageously black-mailed the Irish government into making good on its guarantee [of all senior bank debts announced in October 2008] by threatening to cut off liquidity to the Irish banking system - in effect, threatening to force it out of the euro" (Legrain 2014, 68-69). However, from the ECB's perspective, the uncomfortable choice may have been to either realize sizeable losses on its very large exposure to Ireland already existing at the time (in case of an Irish default and/or euro exit) or to see that exposure balloon even further without any government backstop behind it (in case Ireland stayed out of a troika program), risking legal challenges in Karlsruhe and Luxembourg. In the context of the parliamentary inquiry in Ireland in April 2015 Trichet defended the ECB's actions by pointing out that the ECB's liquidity support to Ireland's banking sector at the time amounted to 100 percent of Ireland's GDP: “That was one-quarter of the ECB's total lending at the time and was totally unprecedented. ... We helped Ireland more than any country; more than any central bank did for any country" (quoted in Boland 2015). ${ }^{46}$

Ireland neatly - and early on - demonstrated the strong and mutually infective interdependence between banks and sovereigns that has become known as the "doom loop" (Merler and PisaniFerry 2012). In fact, Ireland had been the initial focus of attention well before the Greek crisis erupted. Given that its banking system was about six times the size of its GDP, Ireland was particularly vulnerable to banking losses. Ireland's property price bubble had started to burst a littler earlier than the U.S. bubble. Ireland was the first euro-area member country to extend a blanket guarantee to bank creditors in October 2008 (Petrovic and Tutsch 2009). (Germany, which was particularly exposed to Ireland, especially through Hypo Real Estate's Depfa, was next.) Following on the footsteps of the bailout of Germany's Commerzbank, the nationalization of Anglo Irish on January 15, 2009 triggered a fresh burst of market panic (Mody 2009). It is noteworthy that Germany's then-finance minister, Peer Steinbrück, proclaimed in February

establish the SMP, only to later turn publically against it, which, among other things, ruined his chances of succeeding Trichet as the ECB's president in the following year and did not do the Bundesbank's standing much of a favor either.

${ }^{46}$ Mario Draghi's letter of February 17, 2015 to Matt Carthy, member of the European Parliament, specifies that Eurosystem liquidity support of the Irish banking system (including ELA) reached about $€ 140$ billion or 85 percent of Irish GDP by November 2010 and then rose to almost $€ 160$ billion or 100 percent of Irish GDP by February 2011 (Draghi 2015c). I will refrain here from speculating about conceivable connections between the peculiarities of the Irish ELA discussed above and the ECB president's controversial role in Ireland's troika bail-out program. 
2009 that "the euro-region treaties don't foresee any help for insolvent countries, but in reality the other states would have to rescue those running into difficulty" (Benoit and Barber 2009). The kind of rescues of euro partner countries rather than banks - improvised on the spot since unforeseen in the treaties - that occurred in 2010 and after, for long failed to effectively stem contagion across the union as national governments remained on the hook individually, backstopping their respective banking systems while themselves acting without safety nets (including a lender of last resort).

The divorce between the monetary and fiscal authorities that we identified in section 3 (above) as the regime's ultimate vulnerability is behind the infamous bank-sovereign "doom loop." The two parties in the doom loop, banks and the national sovereign, are closely intertwined in terms of their liquidity and solvency status. Banks typically hold debts issued by their sovereign as liquid and safe investments; government debt securities also play a critical role as collateral and the financial system's safe asset more generally. A sovereign debt downgrade can therefore have a profound impact on banks in particular. The sovereign, in turn, not only relies on banks as lenders/investors, but is also their ultimate fiscal backstop when banks need to be recapitalized to avoid a wider financial meltdown. National treasuries have notionally retained fiscal policy authority, but lacking a central bank partner they have lost effective control over national fiscal affairs, just as NCBs have lost control over national monetary affairs. Banking problems can have severe budgetary consequences - and are therefore best prevented in the first place. Not being in a position to prevent a financial meltdown when banking problems materialize can be even more costly though (see section 6 , below).

The following year (2011) turned out to be another year of two rather contrasting halves. While growth momentum slowed from the initial rebound in 2010 as fiscal policy shifted to unconditional austerity continent-wide, markets stayed relatively calm during the first half of the year. Portugal became the third country to enter a troika "bail-out" program in May 2011. Under its outgoing president, Jean-Claude Trichet, the ECB even took the courage to hike interest rates twice - in April and again in July 2011 — by 25 basis points each. Once again the bank had allowed itself to get carried away by perceived inflation risks. The premature hikes were reversed in November and December, now under the leadership of Mario Draghi who also expanded the ECB's crisis management weaponry as market turmoil once again escalated. 
Apart from reactivating the SMP ${ }^{47}$ which had stopped making purchases in March $2011,{ }^{48}$ and the launching of another Covered Bond Purchase Programme (CBPP2) in November 2011 (this time for a targeted volume of $€ 40$ billion by October 2012), as well as initiating fresh rounds of six-month and twelve-month LTROs, the ECB also decided to run two three-year LTROs under fixed rate full allotment tender procedures, featuring the option of early repayment after one year (i.e., starting in January 2013). ${ }^{49}$ The banks' take-up in the first operation in December was nearly $€ 490$ billion, followed by another nearly $€ 530$ billion in the second operation in February 2012. While the liquidity obtained in these very long-term refinancing operations (VLTROs) was partly used for repayment or in lieu of shorter-term LTROs, the result was a net liquidity boost of around $€ 500$ billion.

The ECB's new VLTROs expanded the ECB's balance sheet towards and slightly beyond $€ 3$ trillion, but it would be a mistake to interpret the liquidity and balance sheet expansion in 2012 as a properly proactive and expansionary monetary policy initiative. Instead, as all other previous LTROs, the ECB was merely responding to the banks' surging liquidity preferences and passively providing central bank liquidity as extreme market stress continued until August 2012.

The euro area experienced a quasi-internal balance of payments crisis at the time, as capital flows suddenly stopped and reversed, leaving the euro interbank markets fragmented along national lines. As solvency concerns went rampant, banks in the crisis countries subject to sudden reversals were unable to refinance in markets. In order to prevent impending distress selling and the actualization of insolvency on their part, the ECB had to step in as lender of last resort.

As a result, much of the euro interbank market effectively moved onto the Eurosystem's balance sheet as banking systems in the euro area's current account deficit (and crisis) countries engaged in emergency borrowing from the Eurosystem, while banking systems in the euro-area current

\footnotetext{
${ }^{47}$ In 2011 , a total amount of $€ 144.6$ billion was purchased under the SMP, reaching a total settlement amount of over $€ 210$ billion by the end of the year, just short of the peak level of $€ 220$ billion of February 2012, when purchases ended. Ireland and Portugal entered EFSF/IMF rescue programs in late 2010 and May 2011, respectively. ${ }^{48}$ The ECB had not publically announced the freezing of the program. Bastasin (2015) reports that the ECB's decision followed its disappointment about the governments' slow progress in establishing the later ESM and granting it authority to purchase government debt securities in the secondary markets, as well as failure to establish more automatic fiscal discipline by "strengthening" the SGP.

${ }^{49}$ The rate of the three-year LTROs was fixed at the average rate of the MROs over its lifetime.
} 
account surplus countries piled up precautionary balances using the Eurosystem's deposit facility. In fact, use of the deposit facility reached $€ 800$ billion in June 2012. When the ECB cut its key policy rate by 25 basis points to 0.75 percent in July, and in this context also cut the interest rate on the deposit facility to zero, the banks in surplus countries started holding a large part of the surplus liquidity on current account instead, so that "excess reserves" proper first became an issue at that point. EONIA continued to stay closer to the rate on the deposit facility rather than the ECB's key policy rate, as had been the case ever since the switch to fixed term full allotment tender procedures.

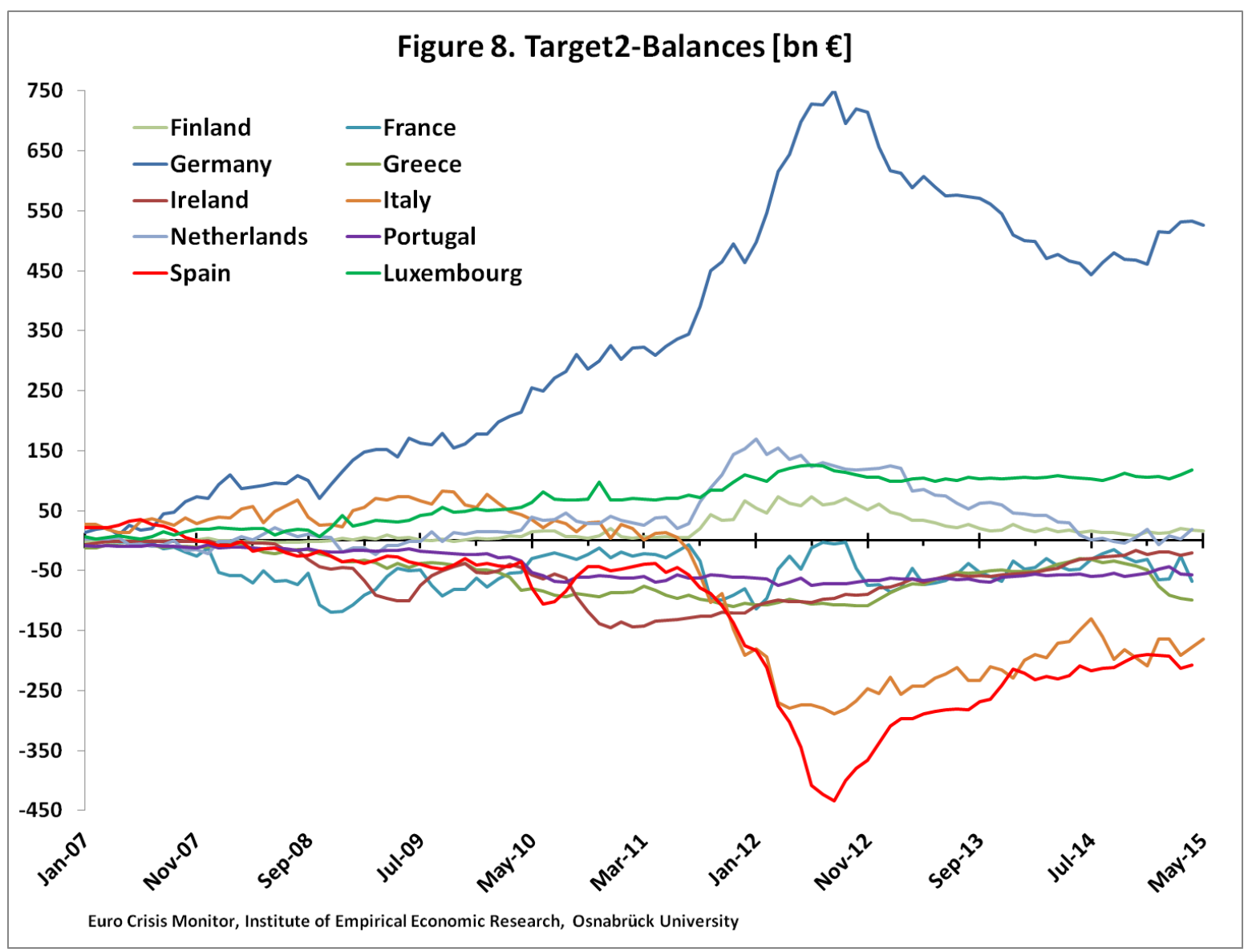


Due to the technicalities in the construction of the euro currency union, the phenomenon discussed here - the quasi balance-of-payments-cum-banking-crisis - also showed up as the infamous "TARGET2 imbalances," which gave rise to much irritation and confusion. ${ }^{50}$ In case of a uniform (one-tier) central banking system, a deposit flight scenario from, say, Spanish banks towards German banks would simply show up as a decline in reserve balances held at the common central bank for the former and corresponding rise for the latter. With the Eurosystem's two-tier balance sheet, the NCBs' balance sheet provides an extra level between the banks and the ECB, with TARGET2 imbalances reflecting the underlying phenomenon: certain banks are in trouble and in need of recourse to a lender of last resort. If no LOLR picks up the emergency call, the banks subject to deposit flight would likely fail—and quite likely with negative repercussions also impacting the recipient banks of flighty deposits and the system as a whole.

Two things are important here. First, apart from the marginal lending facility, emergency liquidity is not generally available by some automatism or overdraft; they require a decision by the central bank to be ready to provide loans against collateral on certain conditions. Second, a refusal by the Eurosystem to act as LOLR in some way would leave the euro payment and money market system completely fragmented - apart from allowing a banking crisis to unfold in full - effectively ending the single monetary policy and euro currency union. Emerging TARGET2 imbalances reflect the overall (cumulative) balance of payments positions of euroarea members that is not (or: no longer) recycled by the national banking system(s) or otherwise settled. ${ }^{51}$ In essence, the ECB handed German banks a massive favor by enabling them to pull out of their interbank lending to bank counterparties in euro crisis countries largely without loss (Bibow 2012a,b, 2013c; Soros 2012). Their exposures were elegantly shifted onto the Bundesbank's balance sheet instead. ${ }^{52}$ Figure 8 shows that TARGET2 imbalances peaked in the

\footnotetext{
${ }^{50}$ Germany's Hans-Werner Sinn (2011a,b, 2012; also with Wolmershäuser 2012) has been quite notorious for confusing the substance of the matter, even suggesting to either cap TARGET2 imbalances or add some settlement mechanism to the system inspired by the U.S. Federal Reserve System. It would be most humorous if TARGET2 debtor countries were asked to settle their balances once a year by handing over government bonds. As the Bundesbank would acquire the, say Greek and Spanish, public debts without intervening in either primary or secondary markets, perhaps this avenue would avoid fresh attempts to get Karlsruhe active. On TARGET2 imbalances see also Bibow (2012a, 2013c) and Cecchetti et al. (2012).

${ }^{51}$ On TARGET2, see Bundesbank (2012), Annual Report (2011, 48-50), and the ECB's Target Report 2011, http://www.ecb.europa.eu/pub/pdf/other/targetar2011en.pdf.

52 The risks associated with TARGET2 balances only materialize in case of a euro exit/breakup. Reichlin (2013) observes that the ECB in "its role as intermediary in the interbank market has indirectly created a transfer from the
} 
summer of 2012. The Bundesbank's TARGET2 creditor balances peaked at $€ 720$ bn (or 27 percent of GDP and more than half of Germany's net international investment position at the time). The steady trend decline seen thereafter (except for the temporary rise in Italy's balance in the second half of 2014) came to an end only more recently in the context of developments in Greece.

Providing huge amounts of emergency liquidity to the system as a whole also involved a further easing of collateral requirements. While loans were offered on equal terms area wide, actual national take-up varied a lot (and was far out of sync with the ECB's capital key), with liquidity demand concentrated in euro crisis countries. In fact, given the concentration of stress in certain countries, collateral requirements had to be eased to the point that these countries' banks were enabled to stay afloat. In the context of the VLTROs the ECB once again allowed the NCBs, as a temporary measure, to accept additional credit claims (ACCs) determined at their own discretion and for their own risk. This was a departure from the "Single List" framework for collateral introduced in 2007, through which the ECB had achieved a high degree of harmonization of the collateral framework in the euro area. Previously only bank debts were eligible as collateral if traded on a regulated market. ${ }^{53}$

weaker countries of the periphery to the stronger countries of the core. The safer countries have been allowed to extract a rent since the risks on their banks' balance sheets are transferred to the ECB (through repo funding) while their funding costs are kept low by the scarcity of safe counterparties."

${ }^{53}$ See Maharaj et al. (2012), Wolff (2014), and the ECB's online collateral data: http://www.ecb.europa.eu/mopo/assets/charts/html/index.en.html 


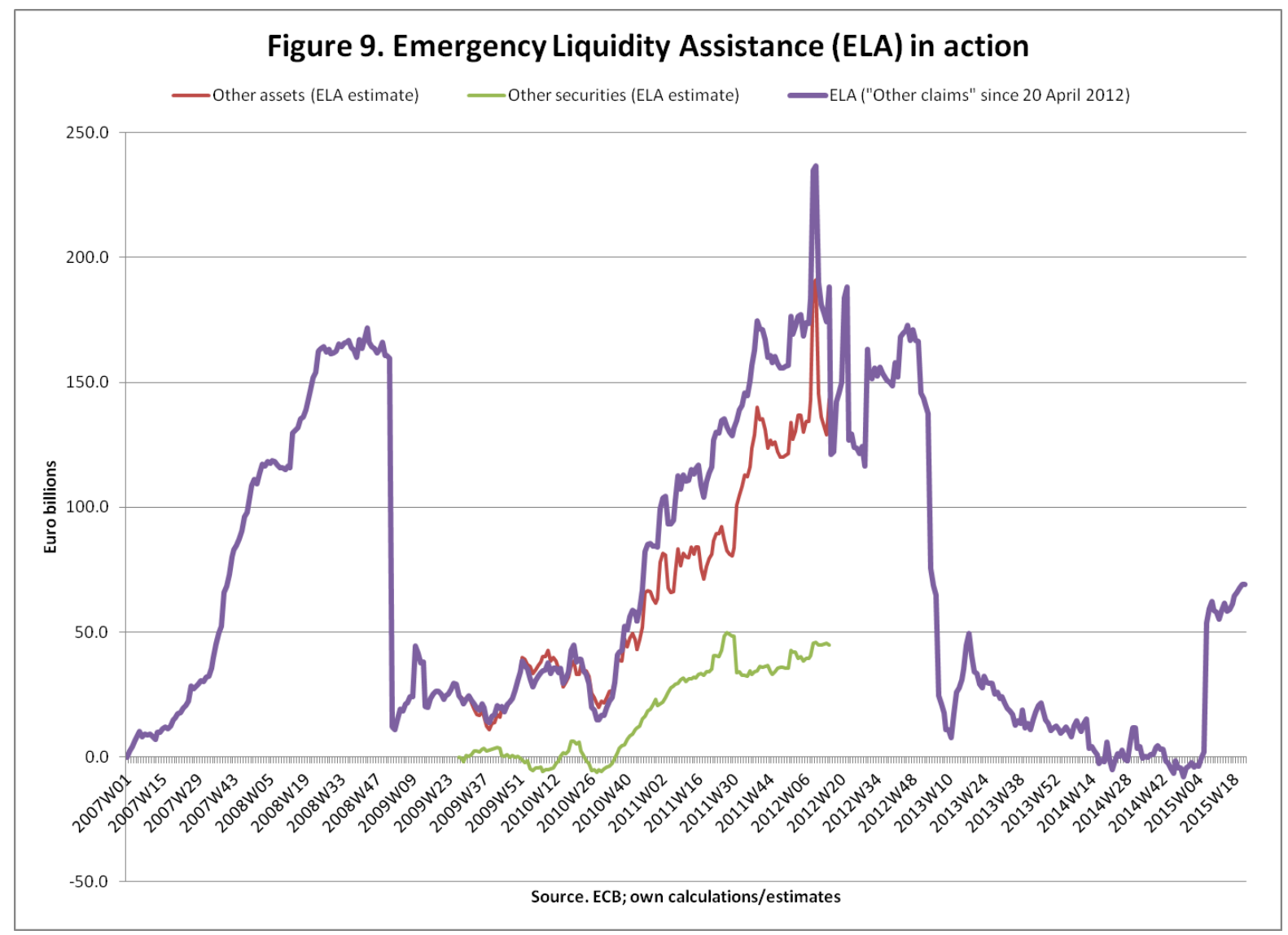

In addition to the joint emergency liquidity provision that crystallized in the ECB's VLTROs in late 2011 and early 2012, emergency liquidity demands were also met by the NCBs as Emergency Liquidity Assistance (ELA), reflecting local shortages of collateral that would fulfill the ECB's requirements. ELA is more expensive from the banks' perspective, while risks are not mutualized but stay with the respective $\mathrm{NCB}(\mathrm{s})$. ELA had made appearances previously but surged during the most acute phase of the euro crisis in 2012, and again more recently (see figure 9)..$^{54}$

\footnotetext{
${ }^{54}$ ELA can only be approximated, as the ECB does not publish the actual data. Prior to April 20, 2012 ELA was included under "Other assets" and "Other securities." Since April 20, 2012 it appears under "Other claims on euro area credit institutions denominated in euro" in the ECB's statistics, amounting to $€ 121$ billion on that date. It appears that the Bundesbank and National Bank of Belgium were the first to use ELA, shortly after the Lehman bankruptcy. The Bank of Greece used ELA during the Greek debt restructuring in 2011-12 and is also behind the most recent surge in ELA following the suspension of the Greek collateral "waiver" in its regular lending facilities on February 4, 2015. See also Buiter, Michaels, and Rahbari (2011), Buiter and Rahbari (2012a), Whelan (2012a), Milligan (2012), MoU (2005), ECB (2008) Convergence Report, and ECB (2007).
} 
In addition, it is also noteworthy that the ECB cut its reserve requirement ratio in January 2012 from 2 percent to 1 percent "in order to support bank lending and liquidity in the euro area money market" (ECB 2011, Annual Report 2010, 84). In effect, this measure largely offset the liquidity drainage that arose from the increase in government deposits held at the Eurosystem in 2012 (supposedly for precautionary reasons). Finally, the dollar swap lines, which had been extended twice in 2011, were extended once again (this time until February 2014) as dollar funding shortages made a reappearance.

Overall, the period from August 2011 until the fall of 2012 presented the most serious challenges to the ECB up until today. One major initial scare concerned a looming restructuring of Greek sovereign debt. On Chancellor Merkel's insistence, she and President Sarkozy agreed on "adequate participation of private creditors" at the Franco-German summit in Deauville in October 2010. In the course of 2011 it increasingly dawned on the markets that "private sector involvement" (PSI) was really coming in one form or another, provoking bouts of panic and self-fulfilling runs on sovereign debt that spread to Ireland, Portugal, Italy, and Spain, and even triggering temporary spikes in the risk spreads of Belgium and France - clear signs that contagion had reached the very heart of the euro area. As is well known since at least Bagehot, liquidity runs can end in insolvency. Europe's currency union had neither a designated lender of last resort for sovereigns nor any proper fiscal backstop in place to stem contagion. The monetary financing prohibition and the no-bailout clause had been considered über-important, not to be compromised by moral hazard.

The Greek debt restructuring was finally completed in March 2012. On the ECB's insistence, the PSI was meant to be "voluntary" in an attempt to avoid a "credit event" that would trigger credit default swaps. ${ }^{55}$ Negotiations to reach a voluntary agreement gave the private sector players involved another chance to contain their losses. In this way, the voluntary "debt exchange" triggered only limited troubles at that point (except a little later for Cyprus). The ECB, too, managed to swap its own exposures beforehand into new debts so as to avoid losses altogether. It appears that the avoidance of losses on Greek sovereign debts had become the ECB's primary objective at that time. At any rate, the restructured Greek sovereign debt moved

\footnotetext{
${ }^{55}$ The ECB was adamant about avoiding an official restructuring. See, for instance, Trichet's statement made at the press conference on July 7, 2011: "I have already said what our message for those who are in charge was, and that message was: no credit event, no selective default, no default. That is the message of the Governing Council." See Zettelmeyer, Trebesch, and Gulati (2012); Whelan (2013b); Bastasin (2015); and Legrain (2014).
} 
from private to official balance sheets. In contrast to the old debts, the new debts were issued under English law, which meant that the Greek parliament had lost effective power over them.

While this episode of the Greek "sovereign debt" drama was finally brought to a close, the much bigger worry was actually about Italy and Spain. The two countries were simply too big to be handled by the ESM, which was not even set up at the time and only featured a limited capacity of $€ 500$ billion anyway. According to the ECB, the escalation of market turmoil that reached its peak in mid-2012:

mainly reflected a perceived lack of determination on the part of governments to take the necessary steps to resolve the crisis and to implement agreements made at the European level. Markets particularly focused on the potential repercussions of uncertainties in Greece, and on developments in Spain and Italy, amid fears about the sustainability of government debt and constrained access to the funding market. These fears led to exceptionally high risk premia, related in particular to unfounded concerns on the part of investors about the reversibility of the euro. (ECB 2013, Annual Report 2012, 15)

In response, the ECB launched its even more controversial successor program (replacing the earlier SMP) called "outright monetary transactions" (OMTs). Following the leaders' declaration on "banking union" in June 2012, which had only little immediate impact, Mario Draghi hit the markets' nerve in a speech in London in late July, famously declaring that the ECB stood ready to do "whatever it takes to preserve the euro," adding: "and believe me, it will be enough" (Draghi 2012). ${ }^{56}$ The ECB quickly followed up by its first official announcement on "outright open market operations" following the Governing Council meeting on August 2, 2012. ${ }^{57}$ Staunchly criticized by Bundesbank president Weidmann, but ultimately endorsed by

\footnotetext{
${ }^{56}$ Veron (2015) emphasizes the connection between banking union and OMT. Draghi (2014a) argues that banking union had to be the initial step in a consistent strategy to restore the singleness of money (and monetary policy):

\begin{abstract}
The banking union had to be the first step of a longer sequence, for two reasons. First, because it was necessary to consolidate the single currency. Second, because it provided an opportunity to "reboot" the euro area banking system, which in turn is a pre-condition for the recovery. [He then goes on to explain that the fungibility of money in the form of bank deposits] was threatened initially by the fragmentation of financial markets in the euro area, and then exacerbated by the emergence of redenomination risk in financial prices. Those unfounded fears of redenomination put price stability at risk, which the ECB had to alleviate through the creation of its Outright Monetary Transactions (OMT) programme. Our actions underlined the irreversibility of the single currency and were decisive in restoring confidence
\end{abstract}

De Santis (2015) measures "redenomination risk" and finds that Mario Draghi's London speech marked the turning point. See also De Grauwe and Li (2013).

57 The introductory statement to the press conference reads: 
Chancellor Merkel, the ECB published the details of the OMT modalities in September 2012, at which time the SMP was officially terminated. OMTs would focus on sovereign bonds with a maturity of between one and three years. No ex ante quantitative limit would be set. And the liquidity created through purchases would be fully sterilized. ${ }^{58}$ The introduction to the press conference of September 6, 2012 focuses on price stability and the aspired "singleness" of monetary policy but also states that the euro is irreversible:

\begin{abstract}
We aim to preserve the singleness of our monetary policy and to ensure the proper transmission of our policy stance to the real economy throughout the area. OMTs will enable us to address severe distortions in government bond markets which originate from, in particular, unfounded fears on the part of investors of the reversibility of the euro. Hence, under appropriate conditions, we will have a fully effective backstop to avoid destructive scenarios with potentially severe challenges for price stability in the euro area. Let me repeat what I said last month: we act strictly within our mandate to maintain price stability over the medium term; we act independently in determining monetary policy; and the euro is irreversible.
\end{abstract}

The commentary in the 2012 Annual Report states that, while OMTs have helped to alleviate financial market tensions, the ball was now in the governments' court:

the Governing Council will independently consider conducting OMTs to the extent that they are warranted from a monetary policy perspective in the event of market fragmentation. OMTs are aimed at supporting the transmission mechanism in all euro area countries and the singleness of the monetary policy. They provide a fully effective backstop to avoid destructive scenarios with potentially severe challenges for price stability in the euro area. The announcements about OMTs helped to alleviate tensions in financial markets and reduced tail risks and uncertainty in the second half of 2012 . ... However, the situation remains fragile as long as the root causes of the current crisis are not fully addressed. This can only be done by governments, which need to ensure sustainable public debt, make their economies more competitive, strengthen the resilience of their banks, and continue to improve the institutional setting of EMU. (ECB 2013, Annual Report 2012, 16)

The Governing Council extensively discussed the policy options to address the severe malfunctioning in the price formation process in the bond markets of euro area countries. Exceptionally high risk premia are observed in government bond prices in several countries and financial fragmentation hinders the effective working of monetary policy. Risk premia that are related to fears of the reversibility of the euro are unacceptable, and they need to be addressed in a fundamental manner. The euro is irreversible. ... The adherence of governments to their commitments and the fulfilment by the EFSF/ESM of their role are necessary conditions. The Governing Council, within its mandate to maintain price stability over the medium term and in observance of its independence in determining monetary policy, may undertake outright open market operations of a size adequate to reach its objective.

See http://www.ecb.europa.eu/press/pressconf/2012/html/is120802.en.html

${ }^{58}$ See the ECB's press release of September 6, 2012 on the technical features of OMTs http://www.ecb.europa.eu/press/pr/date/2012/html/pr120906 1.en.html 
Market calm gradually began to return in late summer of 2012. The CBPP2 ended on time in October after only purchasing $€ 16.4$ billion, mainly due to a lack of covered bond issuance. It is planned to hold the securities in the CBPP2 until maturity but, in order to avoid collateral shortages, they are also made available for securities lending. In January 2013, the volume of central bank liquidity provided and size of the Eurosystem's balance sheet started to decline steadily, owing to mainly two factors: first, banks' early repayment of loans obtained under the VLTROs (by about $€ 440$ billion) and, second, a reduction in recourse to ELA provided by the NCBs. The ECB only used MROs, regular LTROs, and special-term refinancing operations, all at relatively small volumes and under fixed rate full allotment tender procedures. Accordingly, in the course of the year, the banks' excess reserves (held on current account) declined by some $€ 220$ billion to $€ 145$ billion by year end, while their use of the deposit facility declined by $€ 124$ billion to $€ 60$ billion by year end. Also, the volume of securities holdings under the SMP shrank from $€ 220$ billion to $€ 180$ billion owing to redemptions and the Eurosystem's participation in the Irish buy-back operation in December. The volume of fixed-term deposits issued to sterilize the SMP liquidity effect declined accordingly.

The Cyprus debt crisis, which was brought to a close in March 2013 with a $€ 10$ billion troika bail-out, only temporarily interrupted the general picture of declining market stress. To some extent the crisis was a repercussion of the Greek debt restructuring, which delivered huge losses to two major Cypriot banks - which were "too large to save" (bailed-out) by their sovereign (Lindner 2013). The troika bail-out program was highly controversial because it involved writedowns that hit (“bailed-in”) bank depositors with deposits above $€ 100,000$. (Initially, the Cypriot government had even favored bailing-in smaller - supposedly insured - depositors as well; a move which was however reversed.) In this context the ECB was seen as threatening at short notice that the Central Bank of Cyprus would have to cut off Cypriot banks from ELA unless a troika program was agreed to by a certain deadline (Lawton, Buell, and Marson 2013; Steen 2013a,b; Spiegel 2013), suggesting “blackmail” at least to some (as earlier in the Irish case, an accusation that later also reemerged in the Greek context in 2015). Mr. Draghi explained the ECB's position at the press conference on April 4, 2013: 


\begin{abstract}
When the Governing Council objected to Emergency Liquidity Assistance (ELA), it acted within its mandate. It objected to extending ELA to non-viable banks and thus did not replace what could have been fiscal action. [...] First of all, ELA is the responsibility of the national central bank and not of the ECB. It can be extended only to solvent and viable banks. Now, it so happened that in the absence of a programme, these banks would not have been solvent and viable. At that point in time the Governing Council assessed there was no programme in place, and that's why it had to do what it did. On all other occasions there was a programme in place. That's why when people ask us why we didn't do this on other occasions, the difference is that there was a programme in place, which led the Governing Council to assess that banks were solvent and viable. I don't think that the view that we are acting politically is actually correct. We have a mandate, which has been given to us by the legislators, and we are acting within that mandate. (Draghi 2013)
\end{abstract}

The LOLR's life would be easy and comfortable if cases of illiquidity could be easily distinguished from cases of insolvency. They rarely can. Perceived insolvency can prompt illiquidity. A liquidity run can cause insolvency. The ECB appears to fall back on the straightforward rule that a program guarantees solvency (read: likely protects the ECB from losses) and hence enables liquidity support. In the absence of a program, rule gives way to discretion. Since failure to counter a liquidity run can lead to insolvency of entities that would be solvent under normal market conditions, discretion is politically problematic; not least because it also leaves the ECB at risk of being abused by the political authorities, tempted to delay or avoid making hard decisions. ${ }^{59}$ As always, the ECB's foremost fear will be to end up making losses and become subject to legal challenges. The Cyprus "bail-out" included the imposition of capital controls that effectively cut Cyprus loose from the euro currency union temporarily.

On the other hand, the ECB continued to provide U.S. dollar funding through the swap line arranged with the Federal Reserve. In December 2013, the dollar swap line and similarly the bilateral swap lines set up between the ECB and the Bank of Canada, Bank of England, Bank of Japan, and Swiss National Bank, were actually converted into "standing arrangements that will remain in place until further notice" (ECB 2014, Annual Report 2013, 94-94). In essence, these swap lines now constitute the official backbone of global U.S. dollar liquidity as provided by a consortium of key central banks.

Meanwhile, the Eurosystem's supply of euro liquidity was shrinking in line with the demand for it. As had previously been the case with the Eurosystem's balance sheet expansion, its gradual

\footnotetext{
${ }^{59}$ In fact, there is also the opposite criticism leveled against the ECB, namely that ELA was provided for too long, mostly for political reasons, which only delayed resolving the situation and ultimately made it more costly; see Orphanides (2014a, b) who also refers to a report by Stavros Zenios published in Greek in 2013.
} 
shrinkage in the course of 2013 and after did not reflect any monetary tightening per se but the waning of money market tensions and decline in banks' liquidity preference. But it also didn't mean that there was any real improvement in economic performance. In fact, the so-called "recovery" from double-dip recession remained extraordinarily weak and fragile all along. So much so that the ECB finally eased its policy stance further. In May 2013, the key policy rate was cut by 25 basis points to 0.5 percent while the rate on the marginal lending facility was cut by 50 basis points to 1 percent. ${ }^{60}$ In July, the ECB added "forward guidance" to its communication cum expectation management repertoire by announcing that it expected policy rates to remain at present or lower levels for an "extended period of time." And in November, both the key policy rate and the rate on the marginal lending facility were cut by another 25 basis points each to 0.25 percent and 0.75 percent, respectively. The rate on the deposit facility had been held at zero all along (since July 2012). The traditionally symmetric interest rate corridor thus became more asymmetric and the overnight rate declined towards a level of 10 basis points.

Economic fragility was reflected, among other things, in the continued weakness of money and credit. Money and credit growth had decoupled in 2011, as the rate of growth of M3 accelerated from 2 to 4 percent, while credit growth stalled and even turned negative (see figure 5 above). Banks were buying government bonds but not extending credit to the private sector (nonfinancial corporations in particular). This was partly the result of slack demand for credit, and it was partly a reflection of tightening credit standards and bank deleveraging - $\mathrm{a}$ "credit crunch." The ECB had regularly monitored the situation in its "Bank Lending Surveys," which were indicating protracted weakness and tightening of credit standards, but for a long time Europe's central bankers did not feel any urgency about the matter.

The situation only changed in the spring of 2014 as inflation was declining below 1 percent and international pressure on the ECB started to heat up (see Claeys 2014; Claeys et al. 2014; Darvas et al. 2014; IMF 2014a; and Ubide 2014 for instance). All along the Eurosystem's

\footnotetext{
${ }^{60}$ The ECB's justification of the rate cut reads: "These decisions are consistent with low underlying price pressure over the medium term. Inflation expectations for the euro area continue to be firmly anchored in line with our aim of maintaining inflation rates below, but close to, 2 percent over the medium term. In keeping with this picture, monetary and loan dynamics remain subdued. At the same time, weak economic sentiment has extended into spring of this year. The cut in interest rates should contribute to support prospects for a recovery later in the year. Against this overall background, our monetary policy stance will remain accommodative for as long as needed" (ECB 2013, Introductory statement to the press conference, May 2).
} 
balance sheet had continued shrinking as banks opted for early repayment of their loans from the two VLTROs. The level and volatility of EONIA had actually increased slightly since the rate cut of November 2013, as the liquidity surplus in the system that had previously kept EONIA near the zero floor set by the rate on the deposit facility was gradually shrinking.

So at the June 2014 meeting the governing council finally decided to try to stem the process of continued disinflation. The key policy rate was cut by 10 basis points to 0.15 percent, the rate on the marginal lending facility by 35 basis points to 0.40 percent, and the rate on the deposit facility by 10 basis points. This move pushed the latter into uncharted waters: it now stood at negative 0.10 percent. As the negative rate on the deposit facility also applies to any excess reserves held on current account, the banks would from now on pay for any precautionary balances held at the central bank. Given that the ECB's liquidity provision was in passive mode, the existence of excess reserves provided an indicator of a still-dysfunctional money market, a symptom of remaining bank funding issues.

Around that time the ECB had also begun thinking about ways to maintain the level of liquidity in the system or even boost the size of its balance sheet again. The main source of excess liquidity in the system since early 2012, the two VLTROs, was scheduled to dry up completely by February 2015. As the banks made use of their early-repayment option, the process was a gradual one. It was partly as a replacement for the expiring VLTROs that the ECB announced a new series of "targeted long-term refinancing operations" (TLTROs), the first one of which was to commence in September 2014 and additional ones to follow until June 2016, all of which were set to mature in September 2018. ${ }^{61}$

When the VLTROs were launched in late 2011/early 2012 it was quite clear that it was considered desirable if the banks saw the program as an opportunity to invest in government debt (instead of the ECB doing so directly). In the summer of 2014 government debt markets were calm and sovereign risk spreads contained. At this time the predominant concern finally was that the banks' lending to the non-financial private sector was still shrinking and the real economy extraordinarily fragile. So the main motivation was to spark new lending to the real economy - somewhat resembling the motivation for the Bank of England's "funding-for-

\footnotetext{
${ }^{61}$ ECB press releases of June 5, $2014 \mathrm{http} / / \mathrm{www} . e c b . e u r o p a . e u / p r e s s / \mathrm{pr} / \mathrm{date} / 2014 / \mathrm{html} / \mathrm{pr} 140605$ 2.en.html and July 3, 2014 http://www.ecb.europa.eu/press/pr/date/2014/html/pr140703 2.en.html.
} 
lending" program of 2012 and $2013^{62}$; however, the TLTROs exclude loans to households for house purchases. Supposedly the reasoning here was either to prevent banks with housing bust legacy issues to benefit heavily from the program (the "initial allowance" of 7 percent of banks' loan portfolio on April 30,2014) or to prevent stoking fresh housing bubbles (the "net lending allowance" of up to three times of new loans made after April 30, 2014). Instead, the main target of this "credit policy" in disguise that is part of the ECB's "credit easing package" is to alleviate funding squeezes felt by bank-dependent small and medium enterprises (SMEs).

In addition, at the June 2014 meeting, the ECB further prolonged its FRFA tender procedures and announced that it was undergoing preparatory work for outright purchases of asset-backed securities. The prospect of a QE program of some kind, in all likelihood also including outright purchases of government debt, was emerging on the horizon more meaningfully. ${ }^{63}$ In a way, the ECB's suspension of the sterilizing FTOs (by means of fixed-term deposits) under the SMP provided a first tentative step in that direction. Ideologically, ending sterilization marked a big step for the ECB, as it meant the official start of public debt "monetization," albeit purely for monetary policy purposes.

I remarked further above (see fn. 41) that once standard interest rate policies reach their limit, it becomes easier to avoid monetary financing suspicions. The euro area had been more or less stuck in recession and stagnation ever since the SMP was first launched in May 2010,but it took the ECB until the summer of 2014 to finally reach the limit of standard monetary policy (and acknowledge that it has). Technically, the actual switch to a policy of actively pushing excess reserves into the system would only start in earnest once the banks could no longer respond by repaying loans or taking on diminished amounts of central bank liquidity through other operations; although to some extent meeting demands for collateralized loans and outright asset purchases may coexist and complement each other. In any case, with the effective penalty in place on excess reserves, early repayment of LTRO liquidity continued unabated.

\footnotetext{
${ }^{62}$ See http://www.bankofengland.co.uk/markets/Pages/FLS/default.aspx

${ }^{63}$ In March 2014 Bundesbank president Jens Weidmann stated in an interview that QE was not "generally out of the question", which was widely seen as a decisive U-turn that paved the ground for the ECB to eventually embark on the QE path; see Jones (2014) and Randow (2014). However, Weidmann was later to stick to his view that conditions in the euro area would not really warrant QE. The ECB governing council's press statement of April 3, 2014 reads: "The Governing Council is unanimous in its commitment to using also unconventional instruments within its mandate in order to cope effectively with risks of a too prolonged period of low inflation." In the Q\&A of the press conference following the meeting Mr. Draghi confirmed that this statement included QE, which was part of the council's "very rich and ample discussion."
} 
Arguably, the most important effect of pushing EONIA into negative territory was to promote the euro as a carry trade funding currency and weaken the euro's exchange rate. ECB communications since around the time of March had made it clear enough that this was a rather welcome side effect - if not the foremost objective — of the whole measure. In view of both the euro area's external position, its surging current account surplus, and the G-20 commitment to global rebalancing, competitive currency devaluation on the part of the euro area is of course highly problematic.

A more promising avenue for recovery was laid out by Mario Draghi in his remarkable speech at Jackson Hole in August 2014, where he (briefly) departed from the ECB's standard “expansionary fiscal consolidation” doctrine, declaring that:

\begin{abstract}
Demand-side policies are not only justified by the significant cyclical component in unemployment. They are also relevant because, given prevailing uncertainty, they help insure against the risk that a weak economy is contributing to hysteresis effects. Indeed, while in normal conditions uncertainty would imply a higher degree of caution for fear of over-shooting, at present the situation is different. The risks of "doing too little"-i.e., that cyclical unemployment becomes structural-outweigh those of "doing too much"that is, excessive upward wage and price pressures. (Draghi 2014b)
\end{abstract}

Toward that end, Mr. Draghi even identified scope for fiscal stimulus, lending his support to the "Juncker plan," and calling on countries with fiscal space to use it constructively. He also remarked that other countries had fared better since the global crisis because they had a more anti-cyclical macro policy stance. Predictably, Mr. Draghi's Jackson Hole remarks were not well received by the relevant euro authorities - especially the German government was not at all amused-and hence nothing constructive ever came out of it. 


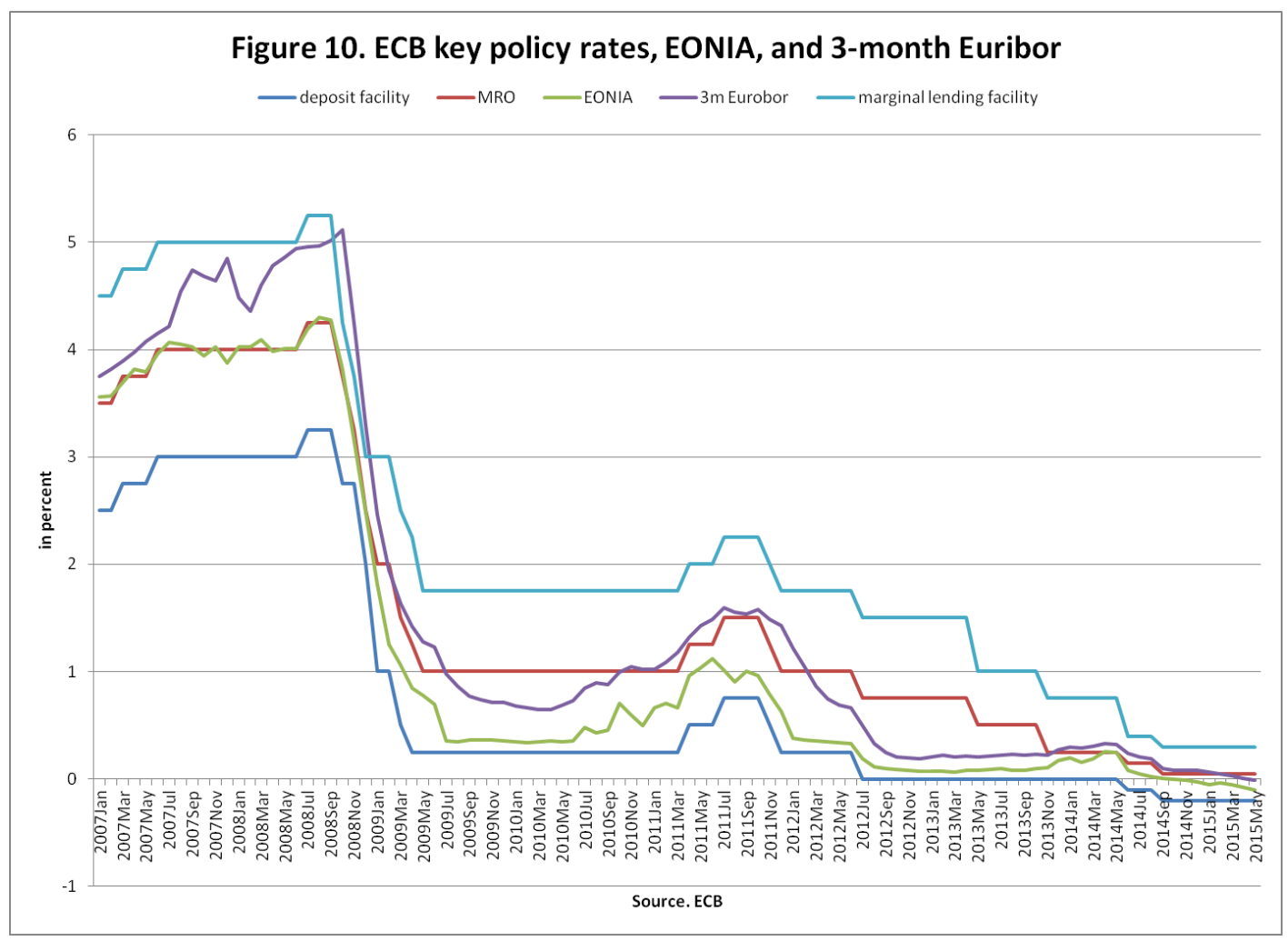

And so the ECB made its next move in September 2014 when it cut all its policy rates further, by another 10 basis points each, reducing the key rate on the MROs to 0.05 percent, the rate on the marginal lending facility to 0.30 percent, and the rate on the deposit facility to negative 0.20 percent. In addition, the ECB announced that it would start purchasing non-financial private sector assets (debts) in October, when it would launch another covered bonds purchase program (CBPP3) and a new purchase program for asset-backed securities (ABSPP), both of which would run for at least two years. A critical issue concerned the riskiness of securities to be purchased under the ABSPP. Once again the potential for losses and loss sharing was the issue. The ECB announced that it would only be willing to buy higher-risk ("mezzanine") tranches if they were covered by a sovereign guarantee. The German and French governments rejected this out of hand. As a result, the ECB has, for the time being, restricted its purchases to high-quality low-risk (senior) tranches.

Both the CBPP3 and the ABSPP may be seen as measures intended to foster the ongoing healing process of euro-area banks. In addition, especially the ABSPP may also be seen as a contribution under the "capital market union" heading (see section 6, below), with asset-backed 
securities providing a bridge between traditional bank intermediation and market finance. (The currently tiny volume of the ABSPP reflects that the aspired "capital market union" has a long way to go though.) By the end of 2014 the ECB had bought a total volume of close to $€ 30$ billion of covered bonds under CBPP3 and nearly $€ 1.8$ billion of asset-backed securities. ${ }^{64}$ Meanwhile, the euro-dollar exchange rate ended 2014 close to $\$ 1.20$ - when it was still close to $\$ 1.40$ in March. Given the weakening of many emerging market currencies since the spring, the euro's effective exchange rate had not depreciated by as much though.

In conclusion, until the spring of 2014 the ECB almost exclusively resorted to purely endogenous liquidity provision techniques: passively meeting the liquidity needs of the euroarea banking system(s) as money markets became dysfunctional and fragmented along national lines under acute crisis conditions. The only (small and temporary) exceptions were the SMP, CBPP, and CBPP2. However, these programs were not only small in size. While the liquidity effect of the SMP was fully sterilized until mid-2014 (to keep up the mantra that no public debt "monetization" must ever occur), the liquidity effects of the covered bond programs, in effect, meant correspondingly lower amounts provided through the remaining liquidity operations. Ultimately, the overall amount of central bank liquidity provided was almost purely endogenous throughout this whole period, the result of rising or falling tensions in money markets, and not greatly affected by the SMP, CBPP, and CBPP2 at all. These special programs, targeting particular market segments instead of offering to provide collateralized loans to banks, may have had some effect on risk spreads and relative yields though, as their supposed purpose was to repair the monetary transmission mechanism.

The ECB's general approach has started to change gradually since the summer of 2014 as the ECB cut its policy rates further so as to steer EONIA into negative territory, launched another covered bonds program (as well as a new program to purchase asset-backed securities), terminated the sterilization of the SMP's liquidity effect, and embarked on a new series of targeted LTROs designed to incentivize lending to the real economy. Given that these new initiatives are taking place against the backdrop of banks' continued use of their earlyrepayment option of the VLTROs of 2011-12, the overall effect on the liquidity situation and

\footnotetext{
${ }^{64} \mathrm{See}$ ECB http://www.ecb.europa.eu/mopo/implement/omo/html/index.en.html
} 
Eurosystem's balance sheet was merely to halt the process of shrinkage that had started in early 2013.

Apart from lowering the level of EONIA into negative territory, and thereby deliberately depreciating the euro, the effect of these programs was to compress risk premiums and generally ease financial conditions to some extent. Alas, the continued process of disinflation (HICP inflation fell to negative 0.2 percent in December 2014) put a damper on any expansionary impulse on the real economy arising in this way. Whether and how much these programs will contribute to overcoming the remaining fragmentation in euro-area financial markets and reestablish the aspired "singleness" of monetary policy will also largely depend on the healing process of euro-area banking system(s), on the reinvigoration of bank credit supply, and market finance.

In this regard, Europe is placing its hopes on the "banking union" project, which will be the subject of section 6. The subsequent section, section 7, will assess the ECB's latest "QE" initiative and remaining options going forward as they present themselves in early 2015.

\section{THE ECB'S EVOLVING ROLE IN FINANCIAL STABILITY POLICY: "BANKING UNION" TO THE RESCUE?}

From the outset the euro currency union featured the stark contradiction between market integration and policy fragmentation: Europe set out to fully integrate financial markets, but failed to match the aspired common market domain with a truly common policy domain. In particular, banks' cross-border activities were actively promoted as a means of fostering the Single Market. Alas, Europe was anything but ready for a major banking crisis (see Veron 2007). The euro crisis provided a reminder of the fact that the provision of modern money is effectively based on a public-private partnership. It may be largely left to private credit institutions to issue monetary financial instruments in the context of their credit and investment activities (increasingly including cross-border engagements), but the sovereign remains the ultimate guarantor of money - as "money is peculiarly a creation of the State" (Keynes 1930, 4). For when the private providers of credit money get themselves into trouble, it is left to the 
sovereign to shore up the banking and payment system — or watch any unfolding financial meltdown take the real economy down with it.

In the euro currency union, national sovereigns are standing behind their respective national banking systems. The euro's arrival encouraged a tendency towards transnational banking and intra-regional integration of banking systems - at least until crisis struck. But the individual banks' and national banking system's ultimate fiscal backstop in times of crisis - and hence its credit rating - has remained ultimately tied to their respective sovereign. With credit ratings of euro-area sovereigns and sovereign bond yields sharply diverging after 2008, proliferating financial fragmentation was a highly problematic side effect (Schoenmaker 2013). Financial fragmentation nullifies the very rationale of both the Single Market and the Single Currency. In this way, the euro crisis rocked and undermined the very foundations of European integration.

The "banking union" project that was launched in 2012 is supposed to finally overcome the systemic incongruity of combining market integration with policy fragmentation. The most important objective of the banking union was to break the infamous (bank-sovereign) "doom loop." The euro-area leaders' declaration of June 29, 2012 reads: "We affirm that it is imperative to break the vicious circle between banks and sovereigns. " 65 Peter Praet, the ECB's chief economist, highlights the vital importance of the matter: "The nexus between banks and sovereigns and financial fragmentation in the euro area are phenomena that contradict the very essence of a monetary union, where monetary and financial conditions should in principle be uniform in the whole union. Plans to establish a financial market union in the euro area are very important, I would say decisive, in breaking the link between financial conditions and countries" (Praet 2013, 7-8).

The euro-area leaders' declaration of June 29, 2012 merely asked the Commission to "present Proposals on the basis of Article 127(6) for a single supervisory mechanism (SSM)." It was quite clear at the time that a proper "banking union" would have to involve more than the announced single supervisory mechanism. In fact, at the Brussels summit of late June 2012, euro-area leaders held out the prospect that "when an effective single supervisory mechanism is

\footnotetext{
${ }^{65}$ See https://www.consilium.europa.eu/uedocs/cms data/docs/pressdata/en/ec/131359.pdf. See Bastasin (2015) on the political haggling over banking union that preceded its eventual launching at the June 2012 summit, with Mario Draghi's famous London speech following shortly after in late July. See also the "Four Presidents Report" of 2012 titled "Towards a Genuine Economic and Monetary Union" (European Council/Van Rompuy 2012).
} 
established, involving the ECB, for banks in the euro area the ESM could, following a regular decision, have the possibility to recapitalize banks directly."

ECB vice president Constâncio (2013) identifies five constituent elements of a banking union: (i) a single rulebook for banks; (ii) a single framework for banking supervision; (iii) a single mechanism for resolving banks; (iv) a common fiscal backstop; and (v) a common system for deposit protection.

In early 2015, it is apparent that the fifth element on Constâncio's list is not going anywhere anytime soon. The Deposit Guarantee Scheme Directive of 1994 only provided minimum harmonization by setting the minimum level of deposition protection schemes (DPSs) EU-wide at $€ 20,000$ euro per depositor. Since 2010 the European Commission developed a number of proposals in this area intended to provide for a path towards a pan-European scheme, but these got nowhere for fear of any potential cross-border transfers that such a scheme could involve. A Directive of April 16, 2014 substantially amends the earlier one by harmonizing the level of guaranteed deposits at (up to) $€ 100,000$. This is in recognition of the experience of deposit flight in recent years when the level of protection still varied greatly between member countries. The directive also provides for the harmonization of the financing of DPSs at a uniform ex ante target level of least 0.8 percent of the amount of the covered deposits (raised through a levy on its member banks). There is however a 10-year transition period for the latter requirement to go into force (so by July 3, 2024) and there is no risk sharing involved at this point. In case of cross-border banking issues the home country is liable for any DGS pay-outs undertaken by any host country DGS with regard to foreign branches of its banks. The introduction of the directive merely features some lofty language on this matter: "In order to take account of the growing integration in the internal market, it should be possible to merge the DGSs of different Member States or to create separate cross-border schemes on a voluntary basis.",66

This arrangement, while representing progress on the previous situation, still falls seriously short of what is actually required. While it has been recognized that a currency union requires that deposits across the union must be valued equally and at par at all times, in case of systemic events on a scale as experienced in recent years, the ability to stem cross-border deposit flightand the concomitant financial fragmentation - through DPSs ultimately continues to depend on

\footnotetext{
${ }^{66}$ See http://eur-lex.europa.eu/legal-content/EN/TXT/PDF/?uri=CELEX:32014L0049\&from=EN
} 
the perceived solvency of the particular national sovereign that is inevitably the fiscal backstopof-last-resort of the respective DPS, with both solvency and redenomination risk being potentially at issue. A common system of deposit protection remains the least-developed element in Europe's banking union. For the time being, interest in it appears to have largely evaporated.

In principle, the idea of a "single rulebook" would seem to suggest full harmonization of all rules, applied consistently across the union. Full harmonization contrasts with the EU's traditional common market principles of minimum harmonization cum "mutual recognition" (Lannoo 2002). Since the late 1980s it has been custom to use the globally agreed Basel banking rules as the baseline for "translation" into EU-wide rules (such as the Capital Requirements Directives), while leaving some considerable discretion to the member states asked to transpose EU rules into national law. In this way, member states enjoyed the liberty of upholding national “specificities.” The EU's Financial Services Action Plan of 1999 (European Commission 1999) promoted regulatory convergence, but succeeded only up to a point as the markets in financial instruments directive, "MiFID," introduced in 2004 under the Lamfalussy procedure upheld the principles of home country control cum "EU passport."

The global financial crisis provided some fresh impetus towards deeper policy harmonization or integration. In response to the crisis the Basel banking rules have been significantly reformed (see BCBS 2011). The implementation process of the latest "Basel III" bank capital adequacy standards (and related rules) is still ongoing (with completion expected by 2019). The latest batch of EU banking rules based on Basel III, the "capital requirements regulation and directive" (CRD IV/CRR) ${ }^{68}$ is in force since July 2013 and implemented since January 2014. It features a far greater degree of harmonization and leaves the member states correspondingly less leeway in national transposition; see Howarth and Quaglia (2013); European Commission (2013); and Lindner, Soemer, and Theobald (2014).

Common rules are the foundation of a level playing field, but common rules are of limited effect if common practices and compliance is not ensured. This is where the single supervisory mechanism (SSM) comes in. Today, the SSM is the most advanced element in the banking

\footnotetext{
${ }^{67}$ See http://eur-lex.europa.eu/LexUriServ/LexUriServ.do?uri=CELEX:32004L0039:EN:HTML

${ }^{68} \mathrm{http}$ ://ec.europa.eu/finance/bank/regcapital/legislation-in-force/index en.htm 
union project. Based on Article 127(6), the SSM entrusts the ECB as the principal supervisor for all banks in euro-area countries (roughly 6,000). ${ }^{69}$ While the ECB has direct supervisory powers over (systemically) "significant" banks,"70 currently a group of 130 banks that make up 82 percent of euro-area banking assets; day-to-day supervision of the "less significant" banks was left to the national authorities. This arrangement was mainly the result of German pressures to keep the country's numerous Sparkassen under national purview. However, if it sees fit, the ECB may assert its direct supervisory authority over the "less significant" banks, too, apart from being the general licensing authority. In any case, the ECB, the national supervisory authorities, and the European Banking Authority (EBA) ${ }^{71}$ are now supposed to act as one common supervisory system, with the ECB responsible for the overall effectiveness of the SSM. ${ }^{72}$

The SSM became operational in November 2014. Before taking on its new, broad bank supervisory authority the ECB engaged in a comprehensive assessment of banks' balance sheets. This assessment consisted of an asset quality review (AQR) focusing on bank-internal valuations of their assets and "stress tests" conducted in conjunction with the EBA, the results of which were published in October 2014. A delicate balancing act was required. Given that previous stress tests since 2010 had proved inadequate, ${ }^{73}$ the authorities were under some

\footnotetext{
${ }^{69}$ See Regulation No. 1024/2013 of October 15, 2013 http://eurlex.europa.eu/LexUriServ/LexUriServ.do?uri=OJ:L:2013:287:0063:0089:EN:PDF

${ }^{70}$ Defined as banks with assets the value of which exceeds $€ 30$ billion and/or asset values in excess of 20 percent of the GDP of the member states and/or judged significant by the authorities.

${ }^{71}$ The EBA was established in 2010 as part of the EU's response to the global financial crisis together with two other EU supervisory authorities - the European Securities and Markets Authority, and the European Insurance and Occupational Pensions Authority (European Commission 2009). EU regulation no. 1022/2013 of October 22, 2013 amends the EBA's status with regard to the euro-area SSM without changing its role for the EU as a whole. See: http://eur-lex.europa.eu/LexUriServ/LexUriServ.do?uri=OJ:L:2013:287:0005:0014:EN:PDF

72 See Deutsche Bundesbank 2014 and the ECB's 2014 “Guide to banking supervision". https://www.bankingsupervision.europa.eu/ecb/pub/pdf/ssmguidebankingsupervision201411.en.pdf?404fd6cb61db de0095c8722d5aff29cd. In the Bundestag debates on "banking union" in late September 2014 finance minister Schäuble observed that putting responsibility for monetary policy and banking supervision in one institution would not be "without problems" and that the announced ABS purchase program (see above in section 5) would be "somewhat unfortunate."

${ }^{73}$ The first EU-wide stress test in 2009 remained unpublished. The second stress test round of June-July 2010, conducted by the Committee of European Banking Supervisors and the national banking authorities, found capital shortages for only seven banks, namely five Spanish saving banks as well as the Agricultural Bank of Greece and Germany's Hypo Real Estate. (See http://www.bbc.com/news/business-10732597). By contrast, Ireland's Anglo Irish Bank, which had been nationalized in 2009, passed the test-only to feature rather prominently as Ireland's "bank-sovereign doom loop" unfolded ferociously soon after. In 2011 the CEBS was superseded by the European Banking Authority, which (in conjunction with the national banking authorities, ECB, and ESRB) conducted another round of stress tests in the summer of 2011, failing eight out of 90 banks, but not the Franco-Belgian bank Dexia, which collapsed spectacularly a few months later due to its sovereign debt exposures. Spain's Bankia added to the embarrassment. See http://www.eba.europa.eu/risk-analysis-and-data/eu-wide-stress-testing and Pignal
} (2011). 
pressure to undertake a more serious checkup of the banks' health this time round. The ECB had a strong incentive to prepare for a "clean deck" before officially taking on its new responsibilities. On the other hand, it could not risk unraveling the prevailing market calm by all-too shocking bank solvency news either, given that the fiscal backing of euro -rea banking systems remains shaky.

Bank stress tests of the kind conducted in Europe and the U.S. in recent years can be criticized on general methodological grounds (see Borio, Drehmann, and Tsatsaronis 2013), and they may be questioned in terms of the degree of adversity of the particular stress conditions assumed by them. For instance, starting from the current position of weakness, the EBA's latest stress-test scenarios included a severe recession (1.7 percent fall in GDP), though nothing comparable to the recent global crisis. Also, it excluded a deflationary scenario, which has become actual reality in the meantime. In any case, some 25 of the 130 banks were found lacking capital at the time, with a quantified capital shortage of $€ 25$ billion, part of which had already been raised by the respective banks prior to the publication of the results. The balancing act was concluded successfully as the announced results did not trigger any major market storm. In short, the latest stress test was received favorably by the markets, based on market perceptions prevailing at the time of publication. ${ }^{74}$

The remaining two elements on Constâncio's (2013) list, the single mechanism for resolving banks and the common fiscal backstop, have made some headway-albeit into unchartered waters. The foremost concerns guiding the initiatives in these two areas were, first, to contain any potential future recourse to taxpayer money overall and, second, to limit any potential risk sharing among member states. In particular, the EU has agreed to "bail-in" rather than "bailout" creditors in future banking crises. The "Bank Restructuring and Resolution Directive" (BRRD; agreed in May 2014 and in force since August 2014, although transposition is still incomplete) enshrines the bail-in principle EU-wide. ${ }^{75}$ The directive provides a single rulebook for the resolution of banks and large investment firms in all EU member states. Banks are

\footnotetext{
74 That does not mean that the stress-test results have not met any criticism. A number of studies have unearthed serious doubts about the validity of the overall favorable assessment of euro-area banks. See Acharya and Steffen (2014), Groen (2014), and Steffen (2014), for instance.

${ }^{75}$ See "Directive 2014/59/EU of the European Parliament and the Council of 15 May 2014 establishing a framework for the recovery and resolution of credit institutions and investment firms." http://eurlex.europa.eu/legal-content/EN/TXT/PDF/?uri=CELEX:32014L0059\&from=EN
} 
required to have restructuring and resolution plans ("living wills") ready for implementation designed to keep taxpayers off the hook and contagion at bay.

Excluding deposits covered by DGSs (up to $€ 100,000$ ) and certain other instruments (covered bonds), the new bail-in principle establishes a pecking order in which capital and liabilities will be used to "recapitalize" an insolvent institution by wiping out claims on the institution, namely shareholders first, then bondholders (by seniority), and finally depositors with balance in excess of $€ 100,000$. The bail-in of at least 8 percent of the institution's liabilities is foreseen before recourse to the Single Resolution Fund (SRF) becomes possible, whose bail-out contribution is capped at 5 percent of the institution's liabilities.

The Single Resolution Mechanism (SRM) implements the BRRD in the euro area and any other participating member states (scheduled to be fully operational on January 1,2016$).{ }^{76}$ The SRM includes national resolution authorities as the operational arm and features the Single Resolution Board (SRB) as its central decision-making body, deciding the fate of any troubled euro-area bank or investment firm participating in the SSM and whether to recapitalize (featuring "bailin") or liquidate the institution. The SRB is also responsible for managing the SRF. The SRF will be constituted from contributions by the banks from participating member states. It has an ultimate target level of $€ 55$ billion to be accumulated over eight years. In principle, the SRF can also borrow additional resources from the markets and impose ex post levies on the banks for recuperation. Initially the SRF will comprise separate national compartments. These will then be progressively mutualized over an eight-year horizon. ${ }^{77}$

Two things about the supposed route of resolution of troubled banks are clear from this design. First, the restructuring and resolution regime is intended to help with future crises, but will only play a limited role in overcoming the legacies of the current one; the regime concerns phased-in future risk sharing rather than past damage-sharing. Second, even the extent of future risk sharing will be rather limited in amount and apply to banks' contributions rather than taxpayer money in the first instance. Any risk sharing of taxpayer money will only arise as a last resort through the ESM, which, supposedly, is thereby meant to function as the ultimate euro-area

\footnotetext{
${ }^{76}$ Currently these are all EU member states except Sweden and the U.K.; however, states that have not joined the SSM cannot participate in the SRM. And while the SSM is open to all EU member states, currently only the euroarea member states, which are obliged to, have actually joined the SSM. http://eur-lex.europa.eu/legalcontent/EN/TXT/PDF/?uri=CELEX:32014R0806\&from=en

${ }_{77}$ http://register.consilium.europa.eu/doc/srv?l=EN\&f=ST\%208457\%202014\%20INIT
} 
quasi-fiscal "backstop." However, the last-resort fiscal backstop ESM is only foreseen to directly inject equity into banks - the amount being capped at $€ 60$ billion-if providing a loan to the national government would push its debt ratio to unsustainable levels. ${ }^{78}$ In short, investor bail-in, the $€ 55$ billion SRF (plus potential additional market borrowing), and $€ 60$ billion are the envisioned euro-area defense against future financial crises. In view of the EU's recent crisis experiences, this kind of defense hardly impresses when compared to the U.S. federal government's $\$ 700$ billion “Troubled Asset Relief Program” of 2008, especially when considering that EU banks' assets as a share of GDP are 300 percent, whereas U.S. banks' assets are only 70 percent, of GDP.

Overall, then, the banking union project shows some promise in certain areas, but does not seem to even come close to ending the bank-sovereign doom loop, while achievement of its other aims therefore remains uncertain, too. At best the banking union is a halfway house, creating a new peculiar imbalance between common supervision paired with—ultimately—still-national fiscal backing. Member states hand over supervisory authority to a common "mechanism" led by the ECB, a common institution, but remain on the hook for any collateral damages that a future financial crisis may give rise to. Ubide (2013) correctly smells "taxation without representation" behind this outcome (see also Hellwig 2014b). It is yet another case of demolishing sovereignty without putting proper risk sharing in place in its stead, which means magnifying systemic vulnerabilities further.

The bail-in idea may seem very attractive at face value: poor taxpayers should not have to bail out rich and reckless bankers - a nice political selling point for sure. But there are serious question marks about bailing-in when it comes to implementation under acute crisis circumstances. In fact, there is the risk that the popular recourse to contingent, convertible capital instruments (“Cocos") recommended by bank regulators to bolster (apparent) bank capital may even have the perverse effect of encouraging more procyclical risk taking and more homogenous behavior. Bail-in securities might then "bring forward and spread a crisis, not snuff it out" (Persaud 2014; see also Persaud 2000; Avgouleas and Goodhart 2014). It is noteworthy that Germany applied only minimal bail-in of creditors of its own failed banks in the global

\footnotetext{
${ }^{78}$ It was originally planned to use the ESM more flexibly for directly recapitalizing banking systems, but Germany later backtracked on earlier promises. See Marzinotto, Sapir, and Wolff (2011); Pisani-Ferry and Wolff (2012); Bastasin (2015); and Veron (2015). Valiante $(2014,13)$ argues that in the U.S. the financial backstop is "formally limited, but de facto unlimited," namely by means of Treasury-Federal Reserve cooperation.
} 
financial crisis. More recent examples in the euro area are the Dutch government's decision to nationalize SNS Reaal in February 2013 and the rescue of the Portuguese Banco Espirito Santo in August 2014. If the authorities are getting cold feet about bailing in rather than bailing out creditors in cases of idiosyncratic bank failures, the credibility of the threat to bail-in creditors when bigger events arise seems to be rather questionable. This would seem to defeat the moral hazard focus of the whole measure as far as creditors are concerned.

Then there is also the issue that bailing-in might lead to even greater injustice than taxpayer bailouts when, for instance, pension funds and insurance companies get hit (by investing in Cocos issued by banks). After all, bailing-in cannot make losses disappear but just passes them on to other designated parties. Whether the bail-in threat will really take care of moral hazard and lead to better risk management on the part of banks remains to be seen.

In the end, I hesitate to put much faith on the bail-in principle to protect the taxpayer. The taxpayer is best protected by, first, proper financial supervision as crisis prevention and, second, courageous crisis management directed at containing any systemic fallout caused by a troubled institution or market. Crisis management needs to be paired with macroeconomic policies that cushion the downturn and foster a timely return to growth. Clearly the ECB will have to decidedly improve on its pre-crisis financial stability policy record and macro-stabilization policies will have to become far more effective, too.

Arguably, the most vital aspect of containing financial panic once it has started rests in the public display of a truly "big bazooka," potentially unlimited emergency liquidity provision by the central bank paired with solvency backstops by the fiscal authority of sufficient amount. If done properly, temporary nationalization of failed institutions may even turn in a profit over time. Bail-in can play a constructive part in cases of idiosyncratic troubles with a specific bank. The idea of general bail-in is a grand illusion when it comes to a system-wide contagion as experienced in the recent global financial crisis. The upshot is that, as hitherto, the banksovereign doom loop will remain a vital a concern in future euro-area crises-and even if the ECB may be unhindered in unleashing its liquidity band-aids over any underlying solvency issues for a while.

The euro area's ultimate source of vulnerability - the absence of fiscal union complementing its monetary union - has stayed very much the same, but the ECB's role has indeed changed in 
important ways. Originally the ECB was only charged with contributing towards the smooth conduct of measures undertaken by the competent authorities in securing financial stability.

Today, the ECB's authority in financial stability policy has been broadened greatly. It is the leader of the SSM, plays part in the SRM, and the ECB is also closely associated with the "European Systemic Risk Board" (ESRB), whose task it is to detect vulnerabilities and to recommend actions to reduce systemic risk in the EU financial sector. The ECB describes its own new role in the following way:

\begin{abstract}
The Eurosystem contributes to the smooth conduct of policies pursued by the competent national authorities relating to the prudential supervision of credit institutions and the stability of the financial system. The ECB provides advice to the European Commission on the scope and implementation of EU legislation in the fields of prudential supervision and financial stability. Furthermore, the ECB provides administrative, analytical, statistical and logistical support to the European Systemic Risk Board (ESRB). From November 2014 onwards, the ECB will be responsible for the prudential supervision of the major banking groups in the euro area and will have important macro-prudential responsibilities. In this context, the ECB will make a major contribution to the financial stability of the euro area. (ECB 2014, Annual Report 2013, 129)
\end{abstract}

In short, the ECB is now explicitly playing far more than just an auxiliary role in financial stability policy. The ECB has assumed the traditional central bank role as "bankers' bank."

The changed situation raises a number of new issues and challenges. If financial stability policy is understood as part of economic policy but separate from monetary policy, the ECB should now be able to also justify certain measures in financial-stability-policy terms rather than solely in terms of monetary policy; the latter being inevitably transmitted to the real economy through the financial system which is now also under its explicit stewardship. This should provide the ECB with more policy leeway overall. In principle, this is as welcome a development as the restrictions arising from the ECJ's opinion on the OMT of January 14, 2015, regarding the ECB's economic policy role in the ESM as part of the "troika." Ultimately, however, the weakness of the established resolution regime, the absent "big bazooka" fiscal backstop, also undermines the ECB's credibility as banking supervisor. Missing a euro treasury partner, the euro area's bankers' bank lacks potency; especially since Europe has shied away from more radical bank re-regulation addressing the "too-big-to-fail" problem head on (see Admati and Hellwig 2013). The usual suspects may worry about perceived threats to the ECB's 
independence as monetary policymaker arising from its new supervisory role. ${ }^{79}$ The lack of a treasury partner and any effective accountability of Europe's newly empowered central bank are far more serious concerns.

Essentially, Europe has merely transformed but not properly resolved the fundamental internal contradiction in its financial stability policy. With increasing financial integration nation states lose the power to provide financial stability on their own, since under such conditions financial stability can only be ensured by properly sharing a common financial stability policy for the common market (dubbed the "financial trilemma" by Schoenmaker [2011]). In one way or another, financial stability policy must include arrangements for fiscal burden sharing; see Goodhart (1999); Goodhart and Schoenmaker (2009); and Schoenmaker (2012). We noted in section 3 (above) that the original role of the NCBs in national and EU financial stability policy was also related to the fact that the euro monetary union is not a fiscal union. A banking union without fiscal union stands on shaky grounds, an unstable half-way house. If Europe's currency union was incomplete without banking union, it remains incomplete without fiscal union. ${ }^{80}$

In closing this section let me add that the banking union project discussed here is not to be confused with another reform effort launched in July 2014 by Commission president JeanClaude Juncker under the title of "Capital Market Union" (Juncker 2014; see also European Commission 2015, Véron and Wolff 2015). The latter project is a longer-term endeavor to transform Europe's current predominantly bank-based financial system towards a more mixed one featuring efficient, resilient, and integrated financial markets (Veron 2014). The two projects are both motivated by Europe's current banking problems and they are also related to some extent; while banking union is supposed to help contain the potential fiscal consequences of future banking crises, capital market union is supposed to contain the economic consequences of future banking crises by reducing Europe's dependence on banks in the first place. Neither project will do much with regard to resolving the current crisis. Capital market union is a distant

\footnotetext{
${ }^{79}$ Playing its traditional role, the Bundesbank took a strongly critical stance on this particular matter. See Pop (2012) and Howarth and Quaglia (2013).

${ }^{80}$ Hellwig (2014a, 34) concludes: "Most importantly, a Europeanization of fiscal responsibility is necessary for the protection of monetary policy. As long as the assignment of fiscal responsibilities prevents a cleanup of the financial system, the independence of the central bank's monetary policy is undermined by the weakness of the financial sector." See also Obstfeld (2013); Hellwig (2014b); and IMF (2014a). An earlier IMF study (IMF 2013) still assumed the possibility of direct ESM bank recapitalization and suggested that the "systemic risk exception" of the U.S. system may be instructive, with resolution operations featuring cooperation between the U.S. Treasury, Federal Reserve, and Federal Deposit Insurance Company (itself backstopped by the U.S. Treasury).
} 
vision towards which the ECB might lend a helping hand by contributing to the development of integrated financial markets. As it stands banking union remains seriously incomplete and will provide only limited support to the ECB's ongoing crisis management challenges. In the short term, the ECB as crisis manager will have to continue operating within the existing predominantly bank-based financial system that remains impaired by legacy problems while transitioning to a reformed regulatory regime - issues which are now also of more direct concern to the ECB as supreme bank supervisor.

The next section assesses the ECB's latest QE initiative and remaining options going forward as they present themselves in early spring 2015. It attempts to provide a realistic assessment of the ECB's role in managing and fully resolving the current crisis. Doing "whatever it takes," can the ECB fulfill widespread hopes and become the euro's savior?

\section{GOING FORWARD: ECB AS THE EURO'S SAVIOR?}

The ECB's crisis management until 2014 has proven effective to the extent that the passive provision of central bank liquidity enabled euro-area banks to bridge liquidity shortfalls arising from fragmented and dysfunctional money markets. By contrast, support for national sovereign debt markets was very limited quantitatively initially (SMP), although purely verbal backstopping (OMT) proved highly effective later on. Moreover, by enticing the banks to purchase government bonds, the ECB's liquidity measures have at times brought important indirect relief to sovereign funding pressures while contributing to recapitalizing the banks along the way.

The ECB has thereby helped to contain mounting pressures for bank deleveraging arising from soaring nonperforming loans and bank capital shortfalls to some degree. On a number of occasions the ECB has defused turmoil and deescalated market panic, preventing the worst. Overall, however, the ECB has consistently done "too little, too late" in stabilizing the euro-area financial system and economy. Lending to the real economy has shrunk for years. By the end of 2014, domestic demand in the euro area was still some 5 percent below its pre-crisis peak level. Moreover, unwarranted disinflation since 2011 left the economy stranded at the brink of 
outright deflation by 2014, creating new challenges to banks and public finances, and the ECB itself.

By early March 2015, interest rates had generally declined to extraordinarily low levels in anticipation of QE finally coming to the euro area. Just before the launching of QE, yields on German public debt had turned negative for maturities up to seven years and were around 0.3 percent at the 10-year maturity, while French 10-year yields were around 0.5 percent, and Italian and Spanish 10-year yields around 1.5 percent. Alas, with nominal GDP growth negligible and HICP inflation below, but close to, zero (rather than 2 percent!), interest rates cannot really be low enough anymore.

As established in section 3 above, the ECB's failure to act in a more timely and forceful fashion to stabilize the economy at least partly owes to legal and institutional constraints. Europe's currency union is inherently flawed (the politically correct term is "incomplete"); the ECB is less powerful than it may appear at first glance, and other economic policies notoriously illguided if not altogether missing. That said, the euro area's dismal post-crisis performance also partly owes to a peculiar asymmetry featuring in the ECB's mindset and policy approach: the ECB is notoriously preoccupied with inflation risks, but strangely complacent when it comes to stagnation and deflation risks. This peculiar asymmetry had already been revealed prior to the crisis (Bibow 2001, 2004, 2006a,b). The past six years have only underlined the bank's conspicuous pathological condition.

Important changes in this regard have only emerged since the summer of 2014. Not only has the ECB become more open in acknowledging that deficient demand is at least part of the euro area's problem; remarkably, the ECB itself has also started to emphasize the need for a symmetric policy approach, highlighting that fighting deflation risks is even warranted purely by its primary price stability mandate. Confronted by the threat of outright deflation the ECB appears to have finally stepped away from its previous approach of politically-conditional monetary policy support towards a more enlightened policy approach that is primarily driven and conditioned by economic conditions. All of a sudden a majority on the Governing Council came to no longer view QE as hindering structural reform but as facilitating it. ${ }^{81}$

\footnotetext{
${ }^{81}$ For instance, in his testimony at a meeting of the EP's Economic and Monetary Affairs Committee in midNovember, ECB president Mario Draghi said that "the ECB has not been created to ensure that governments
} 
I fear that the ECB's belated awakening was born from urgency rather than conviction. The continued decline in inflation and inflation expectations in the course of 2014 together with the striking fragility of the euro area's "recovery" have given rise to the launching of a large-scale asset purchase program in early March 2015 that was first announced following the governing council meeting on January 22, 2015. The idea of boosting the Eurosystem's balance sheet towards the dimensions it had at the beginning of 2012 (a little over $€ 3$ trillion) had emerged in the summer of 2014. Declining inflation expectations caused mounting unease. Disappointment about the outcomes of the new policy measures decided at the governing council meetings in June and September 2014, especially the underwhelming take-up of the TLTROs, was the final factor paving the way for the arrival of quantitative easing in the euro area. Eurosystem liquidity stabilized in September 2014 as the TLTRO merely offset falling LTRO liquidity. A tiny overall increase was then recorded with the December TLTRO. The ECB finally concluded it was time to swap its passive mode of liquidity provision for an active one. If the banks could not be enticed by cheap loans to lend or buy assets, the ECB had to step in the mold and push liquidity into the system by sheer force of its own unlimited buying powers.

It is intended that the ECB's "expanded asset purchase program" (EAPP) will see the Eurosystem purchase public and private sector securities of some $€ 60$ billion per month from March 2015 to September 2016, for a total volume of $€ 1,040$ billion. If it is assumed that purchases of private sector securities under the CBPP3 and ABSPP will continue to be in the order of $€ 10$ billion per month, this would leave $€ 50$ billion or so per month (around $€ 950$ billion in total) for the new "public sector purchase program" (PSPP) set up to purchase marketable debt instruments issued by euro-area central governments, certain agencies located in the euro area, and international organizations and multilateral development banks. ${ }^{82}$ The ECB used flexible language to keep its hands free with regard to the actual duration (and hence ultimate volume) of its EAPP. The statement reads that: purchases are "intended to be carried out until end-September 2016 and will in any case be conducted until we see a sustained adjustment in the path of inflation which is consistent with our aim of achieving inflation rates

actually do the right things [...] we have a mandate.” Apparently many observers have come to expect otherwise from the ECB. In any case, the ECB must shed its old skin and learn to act in a symmetric fashion, and preemptively rather than retroactively.

${ }^{82}$ For instance, while the ECB ruled out the ESM as a counterparty in its standard monetary policy operations (see ECB 2012, Annual Report 2011), securities issued by the ESM will now be purchased in the secondary market as part of the PSPP. 
below, but close to, 2 percent over the medium term." This means that the ECB may decide to end the program early or continue ("open-ended") buying beyond its provisionally foreseen end in September 2016 depending on the governing council's ongoing assessments of the path of inflation.

Purchases of public sector securities of some $€ 50$ billion per month under the PSPP would correspond to roughly twice the rate of purchases made under the SMP in 2010-11, sustained, moreover, for a longer period of time. An important difference to the earlier SMP (and also, potentially, the OMT) is that purchases under the PSPP will not be concentrated on certain euroarea member countries (concurrently experiencing disruptions in the monetary transmission mechanism), but spread across all members - with national quotas following the ECB's capital key. Furthermore, and in contrast to the OMT, maturities are not concentrated at the short end only, but span from 2 to 30 years.

Supposedly the idea here is to squeeze term premia across the whole range of maturities but not otherwise distort the shape of the term structure of interest rates. In fact, the overarching guiding principle appears to be that of "market neutrality" in the sense of aiming to push liquidity into the system in ways that best safeguard market functioning and price formation, echoing the ECJ's ruling of January 2015 (and the Maastricht Treaty's “market economy” references). Towards that end, an issuer limit of 33 percent applies to the universe of eligible assets and the combined holdings of bonds under all purchase programs, which is also meant to "mitigate the risk of the ECB becoming a dominant creditor of euro area governments" (ECB 2015, Q\&A on the PPSP, March 5). In practice, a lower issue share limit of 25 percent-designed to avoid obtaining a blocking minority in the event of a debt restructuring involving collective action clauses - will generally apply though, and hence limit the overall volume of public sector securities that the Eurosystem could potentially purchase. ${ }^{83}$

In a way, aspiring "market neutrality" in implementing $\mathrm{QE}$ also represents a return to more normal monetary policy practices focused on adjusting policy stance in line with economic

\footnotetext{
${ }^{83}$ The higher 33 percent issuer limit only appears to be of any practical relevance in the case of Greece as existing Eurosystem holdings of Greek sovereign bonds previously purchased under the SMP exceeded the 25 percent issue share limit; actually ECB holdings currently exceed even the 33 percent issuer limit, which would initially exclude Greece from the PSPP, even if the "waiver" (of minimum credit rating requirements for acceptance of Greek sovereign and sovereign-guaranteed debt as collateral that was lifted in early February 2015) were re-instated, until mid-2015 when a significant amount of SMP bonds will come due for repayment. See Draghi (2015), ECB press conference, March 5.
} 
conditions rather than repairing financial fragmentation and the monetary transmission mechanism in order to secure the singleness of monetary policy. Essentially, the idea is to push liquidity into the financial system, but leave it to market forces (rather: market players) to shape the ultimate policy impact on asset prices and risk premia. Focusing liquidity injections on public debt seems the most "market neutral" entry point, as public debt is conventionally considered the closest thing to a risk-free instrument (even if that is not strictly true in the euroarea context for lack of monetary sovereignty of the issuers). The other active "credit easing" measures targeting risk premia, in particular private market instruments or segments (CBPP3 and ABSPP), are now more appropriately seen as supplementary measures designed to support the bank healing process and to foster markets.

Meanwhile, the ECB's continued passive liquidity offerings to banks through MROs and LTROs are taking the backseat in the ECB's new three-pronged approach. As before, these collateralized loans are available on area-wide uniform conditions, but in practice the uniform bid-ask spread set by the ECB is more attractive to some banks (from certain countries) than others, reflecting the legacies of imbalances, crises, and market fragmentation. The TLTRO program, of which there are still several more rounds in the pipeline until June 2016, is a hybrid form of passive liquidity provision to banks at uniform rates combining "funding-for-lending" type incentives with the long maturities of the earlier VLTROs.

The ECB's monetary policy has always been implemented in a decentralized fashion, with NCBs providing liquidity in their respective financial centers in line with the decisions made at the center of the system. The controversial center piece in the ECB's new three-pronged approach, the PSPP, is peculiar for the fact that the NCBs' asset purchases will strictly follow the ECB's capital key and concentrate on their respective home markets only. In this way, the mutualization of default risk is meant to be avoided for 80 percent of the program's volume. Only the ECB's own 8 percent share in the additional asset purchases, as well as the NCBs' purchases of securities of European institutions (12 percent of the PSPP), will be subject to the usual regime of risk sharing in monetary policy implementation. In this regard, the PSPP is thus more similar to ELA than monetary policy, although conditions are broadly uniform area wide and set by the ECB. 
It is generally understood that this peculiar feature is a concession to Germany and the Bundesbank, which remained opposed to the PSPP until the end (see Weidmann 2015, for instance). In case of default of any particular national sovereign, losses would only be shared on the ECB's own share in the program, while the respective NCB would feel the brunt of its sovereign's default — and could be easily recapitalized through handing over fresh public debts by its sovereign. An advantage of this peculiar division of the asset side of the Eurosystem balance sheet along national lines based on the ECB's capital key is that it avoids perverse transfers from the troubled periphery to the "safe" core in line with interest rate spreads. The apparent avoidance of loss sharing will only work as foreseen in case of an orderly sovereign default inside the Eurozone - for which the currency union remains ill-equipped. In case of default in conjunction with euro exit or breakup, loss sharing across the Eurosystem balance sheet could still arise in the end through TARGET2 imbalances, which are very likely to experience an explosive surge in the run up to any such event. ${ }^{84}$ What is more important at this point from the perspective of private investors is the fact that the ECB accepts pari passu status with respect to securities purchased by the Eurosystem.

Needless to say the effectiveness of the ECB's latest policy moves remains uncertain at this point. The decline in yields and compression of term and risk premia that had begun in anticipation of the PSPP has continued with the start of its implementation in early March 2015. The biggest immediate impact was registered on the euro's exchange rate, which quickly appeared to be on track to reach parity with the U.S. dollar sometime soon. Germany's DAX duly celebrated the prospect of an even bigger German external trade imbalance accordingly, but other euro-area stock markets, too, got a lift from their relatively depressed levels.

In general, rising stock prices are unlikely to create much of a "wealth effect" on consumption spending in the euro area though. By contrast, the general decline in the level of interest rates will bring some noticeable relief to euro-area debtors of all kinds, including sovereigns. Creditors, on the other hand, will see their interest income shrink further accordingly, causing major headaches for pension funds and life assurance companies in particular. Whether declining interest rates will entice more domestic spending overall will also greatly depend on

\footnotetext{
${ }^{84} \mathrm{Mr}$. Draghi revealed at the press conference on March 5, 2015 that the "ECB up to today has lent to Greece $€ 100$ billion, and more exactly has doubled its lending from $€ 50$ billion to $€ 100$ billion in the last month and a half, the last two months. The lending to Greece today is 68 percent of the Greek GDP, which is the highest in the eurozone."
} 
the response of banks; experiencing a shrinking interest rate margin together with rising collateral values in the process as compressing term premia reduces the profitability of maturity transformation.

Hammered by crisis-related losses, tighter regulation, and the euro area's never-ending recession, it is less than clear that the ECB's latest measures will prove decisive in ending bank deleveraging and fostering fresh credit provision to the real economy. Banks and investors happily moved along in anticipation of the Eurosystem, reaping fairly safe profits along the way. Moving forward from here will be far riskier as the ECB is actually taking (supposedly) risk-free assets off the market on a large scale. Parting with what the Eurosystem set out to buy, banks and institutional investors remain wary to indulge in riskier investments, especially new lending to the real economy. ${ }^{85}$ Signs of improvement remain tentative (see figure 5). One thing is certain: Given the very low entry-level yields, any future QE exit is bound to be extraordinarily complicated, though probably a very long way off at this point, which by itself is an important calming factor. ${ }^{86}$ In the end, the euro area's recovery and success of ECB policy seems to greatly hinge on a big enough impulse gained from net exports through euro depreciation. Given the strength of internal deflationary forces owing to continued pressures for internal devaluation and widespread weaknesses observed in many parts of the world economy, these hopes may well be frustrated.

Arguably, the continued decline in interest rates in March and April may be seen as reflecting considerable skepticism prevailing in the markets regarding the effectiveness of ECB policy in the current deflationary environment, with yields on supposedly safe German bonds pushing ever deeper into negative territory. ${ }^{87}$ The ECB has indicated that it is unwilling to accept (ex ante known) immediate income losses on its purchases by limiting them to government bonds with negative yields of no more than the 20 basis points banks pay for use of the ECB's deposit facility, which, together with current account balances in excess of reserve requirements, will be

\footnotetext{
${ }^{85}$ In order to avoid collateral shortages the ECB is making available for lending the public sector securities purchased under its PSPP and SMP (if eligible for purchase under the PSPP).

${ }^{86}$ The bond market rout of early May 2015 may have provided an early foretaste of things to come. Shortly before its start, former PIMCO "bond king," Bill Gross, had referred to German government debt as the "short of a lifetime" (Gilbert 2015). One may want to recall here Keynes's analysis of liquidity traps and crowded trades (section 3, above). Also his suggestion in The General Theory that a central bank could set more directly any term and risk premia it wanted if it had the guts to accept the impact this might have on its balance sheet—surely a challenge in today's world of liberalized global finance.

${ }^{87}$ The U.S. and U.K. experience showed rising yields in response to the launching of QE initiatives.
} 
the general cash hoard where the banks' excess liquidity will end up. Assuming that the euro will not break up but ultimately survive its ongoing woes, the purchase of bonds with maturities of up to 30 years at today's yield levels is very likely to negatively impact the Eurosystem's recorded profits and transfers to national treasuries at some point in the future. Launching its QE measures so late in the game and at already extremely low interest rate levels, partly for anxiety about cross-partner transfers, has very likely taken a significant bite out of overall future seigniorage income. By contrast, the immediate positive impact on seigniorage will only be small, or even negligible in the case of the Bundesbank.

Just at the time that the ECB has embarked on its belated QE experiment, another episode in the Greek debt drama is unfolding. The supposedly growth-friendly troika policies have crushed the Greek economy sufficiently to augment Greece's debt legacy problems while its populace has got justifiably tired of "more pain with no gain." It seems clear that Greece needs either debt forgiveness or fresh debts to pay off old debts, and the new Syriza government has made it clear it is unwilling to accept the latter if it were to come along with the same kind of - clearly failed - conditionality as previously. Similar to previous situations of this kind, the ECB is caught in the crossfire with regard to LOLR to banks.

Without a program Greek government-guaranteed or issued debts are disqualified as collateral in its monetary policy operations, leaving the Greek banking system dependent on ELA from the Bank of Greece. Given the ongoing process of deposit flight, the ECB has gradually raised its ceiling on the ELA volume set for the Bank of Greece. Can the ECB be accused of blackmailing the Greek government by threatening to cut Greek banks off their last liquidity lifeline? It appears to me that, contrary to the Irish and Cypriot bail-outs, the ECB is taking a less aggressive and more neutral stance. Clearly central bankers, as independent expert monetary technicians, should not be party to the squarely political negotiations between euro creditor and debtor partners. In particular, if anyone is to "pull the plug" in the end, it should not be the ECB. However, the euro's "incomplete" structure (the lack of a federal fiscal backstop) would imply cross-border transfers across the Eurosystem's balance sheet, the potential magnitude of which is a function of how long the political authorities take to reach an agreement while capital flight continues. The ECB will be nervous about potential legal threats that would likely materialize in case a euro exit were to turn the bank's huge and surging 
exposures into losses. On a more positive note, it appears that without QE market stress would be far worse and more widespread than it currently (in May 2015) is.

With regard to the currency union as a whole, if its latest efforts prove insufficient, what more could the ECB do? Quantitative limits only exist for the PSPP ${ }^{88}$ First, there is the 25 percent issue limit. Second, some member states (Luxembourg, for instance) have a small outstanding stock of debt (as a share of GDP). Third, while Germany has a large outstanding stock of debt (75 percent of GDP), its budgetary surplus position is limiting new flows to annual refinancing of about 15 percent of the total. Moreover, German bond yields are most likely to push up against or beyond the minus 0.2 percent yield threshold. ${ }^{89}$ The ECB could create more leeway by cutting the deposit rate deeper into negative territory. This would however contradict Mr. Draghi's announcement made in September 2014 that a floor for euro policy rates was reached at that time and also risk exchange rate tensions, regionally and globally. ${ }^{90}$

In principle, no quantitative limits would appear to exist for the purchase of private sector securities, either in the primary or secondary market, other than the fact that euro-area private debt markets (including asset-backed securities markets) are often relatively small in size and may also involve greater risk than the ECB may be willing to take on its balance sheet without fiscal assurance. ${ }^{91}$ The purchase of foreign assets, U.S. treasury securities for instance, would have exchange rate implications that are too obvious and too starkly in conflict with G-20 commitments to global rebalancing and abstention from competitive devaluation.

Other policy proposals intended to fix the euro crisis and involving the ECB either as assistant or savior have proliferated. Examples include the following.

\footnotetext{
${ }^{88}$ Of the $€ 6.7$ trillion euro-area central government debt outstanding, roughly three-quarters are in the 2-30 year maturity range, currently growing at about 3 percent per year, implying that there may be a $€ 350$ billion (or 7 percentage point) overall margin left by September 2016 (with varying margins among members).

${ }^{89}$ The national Debt Management Offices are likely to extend the (average) maturities of national public debt issuances; this is similar to the U.S. Treasury (Greenwood et al. 2014).

90 The Swiss National Bank and the National Bank of Denmark have meanwhile cut their policy rates well below the ECB's. It almost appears as if the ECB may have quite deliberately left some polite room for its European peers most likely to experience upward pressure on their currencies to do so. What was important from the ECB's perspective was to push short-term euro rates below short-term dollar and yen rates. The U.S. Federal Reserve and the Bank of Japan have (so far) refrained from pushing their respective policy rates into negative territory.

${ }^{91}$ Recall that when Mr. Draghi suggested that finance ministers should backstop ECB purchases of mezzanine ABS tranches, he was promptly rebuffed on that. Constâncio (2014) put the volume of eligible covered bonds at around $€ 600$ billion and the volume of eligible ABS at $€ 400$ billion. See also the ECB's webpage "Eurosystem collateral," which provides information on eligible marketable assets: http:/www.ecb.europa.eu/mopo/assets/charts/html/index.en.html
} 
Tonveronachi's (2014) proposal titled "The ECB and the single European financial market" foresees the creation of a single euro-area market risk-free asset; risk-free financial instruments that would actually be issued by the ECB itself as "debt certificates" (which are explicitly covered by its statutes) by way of purchasing a share of the outstanding national government debt. So the Eurosystem balance sheet would play the role typically reserved for some specialpurpose vehicle or debt agency in various "euro bond" proposals, buying up national sovereign debts and issuing common (mutualized) debts instead, though principally as part of monetary policy implementation. The key idea behind Tonveronachi's proposal is to establish a common term structure of (risk-free) interest rates as the basis for a truly single ECB monetary policy and proper financial market integration.

This very constructive proposal preceded the ECB's actual PSPP, but already foresaw the purchase of public sector debt securities in line with the ECB's capital key. In contrast to the later PSPP its objective is not to push excess central bank liquidity into the system, but to mop up central bank liquidity created through government bond purchases, namely by issuance of ECB debt certificates - as the currently lacking common risk-free asset. The author rightly claims that the proposal would repair at least one important flaw in the Maastricht regime design: the lack of a common risk-free asset and yield curve.

An alternative proposal by Pâris and Wyplosz (2014) features the ECB's balance sheet as the vehicle to achieve "a politically acceptable debt restructuring in the Eurozone" (PADRE). The authors view accumulated post-crisis public debt levels as unsustainable and hindering future growth. Their key idea is to achieve a de facto debt restructuring by way of buying up a portion of national public debts (in line with the ECB's capital key) and swap them into zero-interest perpetuities. As a result, the indebted euro-area sovereigns would get immediate budget relief and regain much-needed fiscal space. The entity that issues debt securities to fund the purchase of national public debts then swapped into zero-interest perpetuities would make losses in perpetuity, though shrinking relative to GDP over time. If this entity were the ECB, these losses would eat into the ECB's future seigniorage income stream accordingly. The use of the ECB's balance sheet would not involve "monetary financing" though as the ECB would issue its own debt instruments rather than central bank money; this is quite similar to Tonveronachi's (2014) proposal in this regard, although the motivation here is government funding rather than 
monetary policy implementation. The scheme is designed to avoid cross-country transfers as the intertemporal seigniorage shifting is aligned with the ECB's capital key.

Whether PADRE addresses the debt legacies of the crisis in a politically acceptable way remains to be seen. Economically, the authors see no need to boost public spending but emphasize the importance of adopting constitutional debt brake rules instead. Regardless of whether or not PADRE may offer a "painless and efficient way of solving debt overhang," as claimed, the promise that "the market reaction is bound to be enthusiastic, which would provide the boost to growth and the broad political support that the euro area so desperately needs" (Pâris and Wyplosz 2014, 2) seems overly optimistic to me.

A “quantitative-easing-for-the-people" proposal by Muellbauer (2014) reserves an even bigger role for the ECB. Starting from an assessment that traditional QE may be insufficiently effective in the euro area, Muellbauer advises the ECB to send each adult citizen a $€ 500$ euro check instead. According to Muellbauer (2014) the ECB could "directly hand out cash to households as part of its method of meeting its inflation mandate. That is why I would classify this as monetary policy and not just a devious way of by-passing Eurozone rules."

Whether the relevant courts might judge QE for the people as legal or not is one thing. Economically, there is an obvious confusion about monetary policy involved here (which is quite symptomatic of monetarist confusions in general). The point is that a central bank is "a dealer in money and debts" (Keynes 1936) rather than an imaginary helicopter dropping banknotes from the sky (Friedman 1963). ${ }^{92}$ Essentially, Muellbauer's apparent QE proposal is nothing but fiscal policy in disguise. ${ }^{93}$ We noted above that monetary policy always has

\footnotetext{
${ }^{92}$ It is quite ironic that Friedman's monetarist "counter-revolution" in monetary theory used fiscal policy to prove Keynes wrong. It is no less ironic that monetarists and other conservatives quite happily ridicule Keynes's humorous remarks in The General Theory about "digging holes in the ground to fill them up again" (with bottles filled with banknotes now hiding in the ground). There is a clear family resemblance between either raining banknotes from the sky or burying them in the ground for discovery. Both cases constitute fiscal policy. See Bibow (2015).

${ }^{93}$ Note that Bernanke (2003) discusses his supposedly "helicopter money" proposal for Japan under the heading of "monetary and fiscal cooperation," referring to a "tax cut for households and businesses that is explicitly coupled with incremental BOJ purchases of government debt—so that the tax cut is in effect financed by money creation." Given the strict separation of responsibilities and other legal constraints discussed in section 3 (above) such an explicit coupling of policy moves would hardly be possible in the euro area. Buiter (2014) discusses both "combined monetary and fiscal policy action" as well as "unilateral helicopter money drops" (and the legality and legitimacy of the latter). The ECB might well commit to boosting inflation toward "below, but close to, 2 percent," in line with its mandate, but it will hardly commit to permanently inflate its balance sheet toward some arbitrary level irrespective of inflation outcomes - assuming that inflation would indeed rise by some monetarist hydraulics.
} 
(re-)distributional side effects, but having independent central bankers make decisions about outright income transfers to citizens would be politically inacceptable indeed.

What is right about Muellbauer's "helicopter-money" idea is that euro-area fiscal policy needs to be more supportive of domestic demand. This can be achieved more directly by boosting public spending rather than through income transfers, investment spending in particular. A reversal of the highly counterproductive austerity policies of recent years, which crushed public investment, is urgently needed. In fact, the euro area has seen a most severe collapse of investment, both private and public.

The so-called "Juncker plan" is a sign of hope that this crucial understanding may be slowly sinking in on the EU Commission's corridors in Brussels. Alas, the Juncker plan foresees rather little extra public borrowing and places much hope on financial leveraging and crowding in of private investment instead (Juncker 2014; EIB 2015). I fear the initiative may amount to little more than a drop in the bucket. There are of course other public investment proposals out there that feature a much bigger fiscal stimulus. Given the euro area's fiscal framework, formidable challenges concern the financing of any stimulus.

No doubt rebalancing the euro area's macro policy mix towards fiscal policy-with the ECB in the role as support rather than supposed savior-seems highly warranted at this point. Perhaps the most important side effect of the ECB's latest monetary policy initiative is to deliver a significant decline in the interest burden on the public debt. A smaller interest burden means reduced pressures for further fiscal consolidation in future years and more fiscal space today. That is very helpful indeed - but not good enough by itself. Rather, it is vital to actually use the available fiscal space to stimulate recovery through increased spending. Continued failure to stimulate recovery now is bound to result in a future bailout of the whole pension fund and life insurance industry in due course, among other things.

Another problem arises here, as became clear at the ECB's press conference on January 22, 2015. During the Q\&A session a question was put to Mr. Draghi that referred back to his Jackson Hole speech of last year. On that occasion, Mr. Draghi declared that it would be helpful for fiscal policy to play a greater role alongside monetary policy in stimulating aggregate demand. As to fiscal policy since 2010 in the euro area compared to the U.S. and Japan, he remarked that greater fiscal support in these countries "reflects the fact that the central bank in 
those countries could act and has acted as a backstop for government funding. This is an important reason why markets spared their fiscal authorities the loss of confidence that constrained many euro area governments' market access. This has in turn allowed fiscal consolidation in the U.S. and Japan to be more backloaded" (Draghi 2014b). With this statement in mind, the questioner asked Mr. Draghi: "Is the ECB, with this QE program, now this kind of support for government funding in the euro area?” Mr. Draghi responded categorically: "Well the answer to [this] question is absolutely no. Absolutely no.” A moment earlier he had also reiterated the ECB's standard position on fiscal policy: "It's very important to have in place a so-called growth-friendly fiscal consolidation for confidence strengthening" (Draghi 2015b). What is going on here, one might wonder?

I suspect the reason for Mr. Draghi's backtracking from his enlightened remarks on the matter at Jackson Hole is to be seen in the ECJ opinion of January 2015 that was published just a week prior to the Governing Council's decision to embark on its PSPP. In the light of that opinion legal prudence requires the ECB to strictly focus its communications on nothing but monetary policy and price stability and avoid any direct connection to the public funding (i.e., economic policy) issue, even if there are, and quite inevitably so, vital side effects involved in that regard. Recall here that the ECJ's preliminary ruling of January 2015 stated that ECB measures must "not be contrary to the requirement for fiscal discipline and the principle that there is no shared financial liability. If there are isolated economic-policy aspects to the measure at issue, the latter will be compatible with the ECB's mandate only as long as it serves to 'support' economic policy measures and is subordinate to the ECB's overriding objective" (ECJ 2015, paragraph 132). Therefore, I believe that the best one can hope for at this point is that the political and monetary authorities, independently from one another, make sound decisions regarding the respective fiscal policy and monetary policy stances required to overcome the euro crisis. For the ECB's part, a symmetric interpretation of its price stability mandate - currently missed by miles - simply requires it to push down interest rates across the board by all means available.

That said, in my view, unless the global environment improves sharply, even the ECB's latest policy initiative in itself is quite unlikely to prevent the euro area from sinking deeper into its self-inflicted debt deflation trap that ultimately risks economic collapse and euro breakup. As a welcome side effect, however, at least the ECB has now established the financial preconditions for a workable fiscal stimulus program that could lead the euro area towards recovery and, if 
well designed, would at the same time heal the ultimate defect in the Maastricht regime's design: the divorce between the monetary and fiscal authorities. Arguably, the needed increase in public spending should not be funded through national budgets. Among other things, this would be at risk of raising suspicions as featured in the January 22, 2015 Q\&A session (and could prompt fresh legal challenges of the ECB along those lines).

An alternative - federal - approach seems more promising and way more appropriate on a number of counts. The euro regime's essential flaw and ultimate source of vulnerability is the decoupling of central bank and treasury institutions in the euro currency union (Goodhart 1997, 1998). The straight-forward way to address this issue (and simultaneously achieve most of the goals of the other proposals discussed above) is to establish a "Euro Treasury"-namely, as a vehicle that pools future euro-area public investment spending, funding it by issuance of proper euro treasury securities (Bibow 2013d). The Euro Treasury would allocate investment grants to member states based on their GDP shares. And it would collect taxes to service the interest on the common debt, also exactly in line with member states' GDP shares. The arrangement amounts to a rudimentary fiscal union, a strictly limited federal system that is not a transfer union, though, as benefits and contributions are shared proportionately. There is also no mutualization of any existing national debts involved. Instead the Euro Treasury debt issuance would fund the joint infrastructure spending that is the basis for the union's joint future. The ECB needs federal treasury debt for monetary policy purposes to avoid its current legal predicaments. The markets need a common safe asset to establish a common yield curve. This is also crucial from the perspective of financial stability policy, the ECB's new mandate in the domain of economic policy. Banks would (with or without regulatory changes regarding sovereign debt; see Goodhart 2007) shrink their holdings of national sovereign debts and hold Euro Treasury debts as their safe assets instead.

Member-states would still be required to abide by all the rules of the current euro regime, but this would apply to current public expenditures only — as national public capital expenditures would form a separate capital budget funded through common Euro Treasury securities. Steady deficit spending from the center will enable the decline of national public debt ratios to low and safe levels. The peculiar vulnerability of the euro currency union would disappear, also because the Euro Treasury would provide the fiscal backstop that is still missing from the banking union. 
Otherwise the Euro Treasury would function on the basis of a strict rule, the so-called golden rule of public finance, which foresees that public investment should be debt financed (Musgrave 1939, 1959). The immediate relief provided to national budgets and boost of public investment from its current depressed levels will act as the needed stimulus to end the crisis. ${ }^{94}$ The ECB's part in all this is merely to pursue its price stability mandate in a properly symmetric fashion. Depending on prevailing economic conditions, this may or may not involve the purchase of public debt issued by the Euro Treasury for monetary policy purposes, but no longer entail national public debt. ${ }^{95}$

\section{CONCLUSION AND POLICY RECOMMENDATIONS}

Contrary to official propaganda, the euro is far from being a success story. The euro area's performance during its first 10 years was unimpressive, marred with severe divergences and soaring imbalances that remained unaddressed until they unraveled under acute crisis conditions, as they eventually would. Matters got only worse thereafter. Economic performance since 2008 has been outright dismal. By the end of 2014 domestic demand was still some 5 percent below its 2008 level and HICP inflation entered negative territory. Among the key global players, the euro area is the by far worst performer, threatening to undermine the global recovery by its surging current account surplus and plunging currency.

Compared to other euro-area and national policymakers, the ECB's policy conduct may stand out positively in certain respects, but, overall, the ECB's performance has been unsatisfactory, too. From the outset its monetary policy approach and mindset has been afflicted by a conspicuous asymmetry that amounts to an anti-growth bias; the ECB seems to be incessantly obsessed with inflation risks, but notoriously complacent with regard to stagnation and deflation risks. As a result, the ECB is always ready to hike, but stubbornly reluctant to ease sufficiently in support of domestic demand.

\footnotetext{
${ }^{94}$ That Europe has a huge investment gap and that public investment spending is an effective way to stimulate growth both in the short and the long run appear to be undisputed facts. See European Commission (2014), IMF (2014b), OFCE/IMK/ECLM (2014), and Abiad, Furceri, and Topalova (2015), for instance.

${ }^{95}$ While De Grauwe $(2011,2013)$ refers to the inherent instability of the current euro regime, note that once the missing Euro Treasury is added to the regime the ECB would decline to act as LOLR to national sovereigns; just as the Federal Reserve does not play that role for U.S. states.
} 
Ironically, its inflation obsession has not helped its inflation record at all. Persistent target overshoots in pre-crisis times owed significantly to increases in indirect taxes and administered prices ("tax-push inflation") that were a consequence of stagnation-triggered budgetary measures. The same phenomenon has also featured prominently in more recent years, probably encouraging the neglect of the patent trend decline in underlying deflation since 2011 that has left the euro area at the brink of outright deflation by the end of 2014 - a remarkable failure on the ECB's primary objective that is intimately related to the dismal outcome concerning its secondary objectives as well. Even with headline inflation bouncing back as the base effect due to last year's oil price slump wears off, core inflation remains extraordinarily low, reflecting ongoing internal devaluations vis-à-vis Germany and area-wide wage repression (while productivity growth has been crushed too).

We emphasized that the ECB is a most peculiar central bank. It was modeled after the German Bundesbank and inspired by the "narrow central bank" vision of the Maastricht Treaty. The ECB was granted exclusive responsibility for monetary policy, but it was not meant to be much of a bankers' bank and a government bank not at all. In fact, there was supposed to be a watertight separation between fiscal and monetary policies in the monetary union, and the ECB was also only granted an ancillary role in financial stability policy beyond the euro payment system. Ultimately this policy structure also stems from the fact that Europe's currency union is not a fiscal union; the euro lacks a federal fiscal capacity.

As it turned out, the legal constraints and uncertainties rooted in this highly abnormal policy structure have also come to hinder the ECB's conduct of monetary policy and capability to act as lender of last resort in crisis. The ECJ's preliminary ruling of January 2015, if confirmed later this year, has brought clarity with regard to some aspects of the legal conundrums surrounding the ECB's monetary policy powers, but the matter can only be properly settled by partnering the ECB up with a federal fiscal capacity. To a significant—and truly unhealthy! — degree the ECB and Europe's currency union remains shackled by German dominance. Today, the reputation and power of both the Bundesbank and Germany's federal constitutional court may be somewhat tarnished, at least outside of Germany, but the German government in Berlin is ruling supreme in European affairs. Ironically, among other things, this situation is in stark conflict with the word and spirit of the Maastricht Treaty and all its emphasis on central bank independence. 
It is undeniable that the ECB's pre-crisis record on financial stability policy, too, was less than stellar. Much in line with other official authorities, the ECB failed to properly assess the riskiness of the euro-area banks' hazardous adventures, both globally and in the region, and the vulnerabilities and fragilities this would give rise to. Regarding internal dynamics in the euro area, the ECB's fatal blunder was to ignore the emergence of stark intra-area divergences in competitiveness positions and the related buildup of financial imbalances. At the time the ECB fallaciously assumed that the "competitiveness channel" would eventually heal the situation by itself. In a way, the ECB remains attached to the same flawed view until today, notoriously pushing structural reforms aimed at raising supposedly insufficient wage flexibility (read: wage cuts) to let the competitiveness channel resolve the euro crisis. Politically, the response was to add the so-called "macroeconomic imbalances procedure" to the Maastricht regime, which is equally asymmetric as all other constituent parts of that regime and has proved decidedly ineffective until now. ${ }^{96}$ If these are really the lessons the euro-area authorities have learned from the crisis regarding internal divergences and imbalances, this would be truly discouraging.

Turning to the ECB's role as crisis manager from 2008 until 2014, it must be acknowledged that the ECB has shown some creativity and flexibility. Its crisis management has proven effective to the extent that the passive provision of central bank liquidity enabled euro-area banks to bridge liquidity shortfalls arising from fragmented and dysfunctional money markets. Owing also to legal constraints, the ECB's direct support for national sovereigns was limited quantitatively initially but proved highly effective later on by purely verbal means (OMTs). Indirect support arose through banks' purchases of national public debt. To some extent the ECB has thereby also helped to contain somewhat the pressures for bank deleveraging arising from regulatory changes, soaring nonperforming loans, and bank capital shortfalls - albeit to an insufficient degree and combined with the risk of further feeding the infamous "doom loop" (should matters take another turn for the worse). On a number of occasions the ECB has defused turmoil and deescalated market panic, preventing the worst; overall, however, the ECB has consistently done "too little, too late" in stabilizing the euro-area economy and financial system.

\footnotetext{
${ }^{96}$ Germany is in conflict with German law, the Commission's imbalance procedure, and G-20 commitments, but Germany's finance minister, representative of Germany's political elite, believes that anyone who fails to see the beauty in German policymaking and stellar performance must be living in a "parallel universe." Who is, really?
} 
Nonetheless the ECB was granted new substantive authority in financial stability policy in recent years. The crisis has turned the ECB into a more normal central bank regarding aspects of the traditional bankers' bank role of central banks. Today the ECB plays a prominent role with regard to the ESRB focusing on macroprudential regulation, and the ECB is in charge of the new SSM, the most developed constituent part of the banking union project. It remains to be seen whether the ECB will improve on its unenviable pre-crisis record with regard to detecting and addressing banking risks and fragilities in a timely fashion. We remain skeptical regarding the effectiveness of the new "bail-in" approach to resolving systemic — rather than idiosyncratic - banking problems. We fear that the current banking union remains a fragile halfway house without proper federal fiscal backing. This limits the contribution banking union can make towards resolving the current crisis and dealing with new future ones.

Some tentative signs of recovery have emerged of late just as the ECB has finally initiated a large-scale asset purchase program, its own peculiar QE variety including public-sector debt securities. The initiative was welcomed by financial markets with some degree of euphoria, but talk of proper recovery seems premature at this point. The euro area has benefited from some temporary tailwinds. It remains to be seen whether the euro area can finally overcome its homemade unresolved crisis that owes both to its internally flawed policy structures and notoriously ill-guided policies. We have significant doubts regarding the effectiveness of the ECB's QE initiative in stimulating domestic demand and establishing a strong and selfsustaining recovery. We are also highly skeptical about the appropriateness of relying even more on external growth stimuli through euro depreciation.

Instead, the euro area must do more to boost and stabilize domestic demand lastingly, namely through an area-wide fiscal stimulus directed at investment in public infrastructure. We refer here to an earlier proposal for a "Euro Treasury" (Bibow 2013d) that would both provide a timely stimulus in support of recovery and heal the Maastricht regime's ultimate flaw at the same time: the divorce between the monetary and fiscal authorities. The plan provides for steady deficit spending on public infrastructure financed through common euro treasury debt, with both investment grants and taxes raised to service debt interest shared in proportion to member states' GDP. This will allow national public debts to decline to low and safe levels over time in line with the fiscal regime currently in place, which would however be applied to national current budgets. 
Euro Treasury debt would become the euro area's common safe asset and basis for a common term structure of interest rates that is a necessary condition for fulfilling the promises of the Single Market and the Single Currency. Bank holdings of national sovereign debts would shrink as Euro Treasury debt takes on the role as common safe asset. The Euro Treasury is the missing federal treasury partner for the ECB and fiscal backstop to the banking union. Indirectly, by pursuing its monetary policy mandate, the ECB would also become a government bank to some extent if macroeconomic conditions so require, but in contrast to today, the ECB would only purchase (federal) Euro Treasury debt but no national public debt. It takes a Euro Treasury to make the no-bailout clause and SGP enforceable.

Given the current intellectual and political climate, any move toward fiscal union —even just a rudimentary fiscal union that follows the age-old "golden rule," a limited fiscal system that is not a transfer union - will not be easy. The ghosts of Weimar and Bundesbank mythology keep haunting the euro, standing in the way of constructive ideas and policies that are urgently needed to secure the euro's survival and, indeed, the whole process of European integration. Recent developments in Greece provided an urgent wakeup call. Muddling through is becoming more and more risky. At some point dismantling the euro may be perceived as the less damaging option or euro exit/breakup result by accident. The "Euro Treasury plan" presents a constructive way forward. For the ECB, a Euro Treasury partner would not be a threat but a blessing. The job of the euro's guardian of stability would become cleaner and simpler. The power to create euro against collateral or assets is a potent crisis management tool—but not guaranteed to boost spending under any circumstances. The ECB may have spared the euro from breakup at the peak of the crisis in 2012, but the ECB itself, acting alone, cannot be the euro's savior. It can only support and facilitate crisis resolution, and play its part in securing shared prosperity. If the jury is still out regarding Mario Draghi's question referred to at the start of this study, whether euro-area members are better off with the euro as their common currency or not, it is safe to predict that the "incomplete" euro will continue to overburden its guardian and remain at serious risk of eventual demise. 


\section{REFERENCES}

Abiad, A., D. Furceri, and P. Topalova. 2015. "The macroeconomic effects of public investment: evidence from advanced economies." IMF Working Paper WP/15/95, May.

Acharya, V.V., and S. Steffen. 2013. "The greatest carry trade ever? Understanding European bank risks." New York University Stern School of Business, Working Paper, March. https://www.stern.nyu.edu/sites/default/files/assets/documents/con_040568.pdf, NBER WP 19039.

- 2014. "Falling short of expectations? Stress-testing the European banking system." Policy Brief no. 315, CEPS, Brussels, January 15.

Admati, A., and M. Hellwig. 2013. The Bankers' New Clothes: What's Wrong with Banking and What to Do about It. Princeton, NJ: Princeton University Press.

Aglietta, M. 2000. “A lender of last resort for Europe.” in C.A.E. Goodhart (ed.) Which Lender of Last Resort for Europe? London: Central Banking Publication.

Almunia, J. 2008. "Foreword." in EMU@10-Successes and Challenges after Ten Years of Economic and Monetary Union. Brussels: European Commission.

Avgouleas, A., and C.A.E. Goodhart. 2014. "A critical evaluation of bail-in as a bank recapitalization mechanism.” International Macroeconomics Discussion Paper Series no. 10065, London, CEPR.

Bagehot, W. 1999 [1873]. Lombard Street: A Description of the Money Market. New York, Willey.

Bank for International Settlements. 2011. "The impact of sovereign credit risk on bank funding conditions." Committee on the Global Financial System Paper 43, Basel.

BCBS. 2011. "Basel III: A global regulatory framework for more resilient banks and banking systems." BIS, Basel, http://www.bis.org/publ/bcbs189.pdf

Barber, L., Q. Peel, and G. Wiesmann. 2010. "Merkel warns of protectionism.” Financial Times, November 8.

Bastasin, C. 2015. Saving Europe: Anatomy of a Dream. Washington, D.C.: Brookings Institution Press.

Benoit, B., and T. Barber. 2009. "Germany ready to help eurozone members." Financial Times, February 18. http://www.ft.com/intl/cms/s/0/825af89a-fe02-11dd-932e000077b07658.html\#axzz3Zpzhvs1E.

Berger, H. 1997. "The Bundesbank's path to independence: Evidence from the 1950s." Public Choice 93: 427-53.

Bernanke, B. 2003. "Some Thoughts on Monetary Policy in Japan." Speech, Tokyo, May. http://www.federalreserve.gov/BoardDocs/Speeches/2003/20030531/. 
Bernholz, P. 1998. "Die Bundesbank und die Währungsintegration in Europa.” In Deutsche Bundesbank, ed. Fünfzig Jahre Deutsche Mark: Notenbank und Währung in Deutschland seit 1948. München: C. H. Beck.

Bibow, J. 2001. "Making EMU work: some lessons from the 1990s." International Review of Applied Economics 15(3): 233-59.

- 2004a. "Assessing the ECB's performance since the global slowdown." Levy Economics Institute, Working Paper No. 409.

- 2004b. "Reflections on the current fashion for central bank independence." Cambridge Journal of Economics 28(4): 549-76.

- 2005. "Germany in crisis-The unification challenge, Macroeconomic policy shocks and traditions, and EMU." International Review of Applied Economics 19(1): 29-50.

_. 2006a. "Inflation persistence and tax-push inflation in Germany and the euro area: A Symptom of macroeconomic policy mismanagement?” IMK Study, 1/2006.

_. 2006b.'The euro area drifting apart_-Does reform of labor markets deliver competitive stability or competitive divergence?" in Structural Reforms and Macro-Economic Policy, ETUC, 76-86.

- 2007a. "How the Maastricht regime fosters divergence as well as instability." in P. Arestis, E. Hein, and E. Le Heron (eds.) Monetary Policies-Modern Approaches. London: Palgrave Macmillan.

—. 2007b. "Bad for Euroland, worse for Germany_-The ECB's record." in J. Hölscher (ed.) Germany's Economic Performance: From Unification to Euroisation. London: Palgrave Macmillan.

- 2009a. "On the origin and rise of central bank independence in West Germany." European Journal of the History of Economic Thought 16(1): 155-90.

- 2009b. Keynes on Monetary Policy, Finance and Uncertainty: Liquidity Preference Theory and the Global Financial Crisis. London and New York: Routledge.

- 2010. "Zur (Re-)Etablierung zentralbankpolitischer Institutionen und Traditionen in West-Deutschland: Theoretische Grundlagen und politisches Kalkül (1946-1967). " in C Scheer (ed.) Die deutschsprachige Wirtschaftswissenschaft in den ersten Jahrzehnten nach 1945, Band XXV Studien zur Entwicklung der ökonomischen Theorie. Berlin: Duncker \& Humblot.

- 2012a. "The Euroland crisis and Germany's euro trilemma." International Review of Applied Economics 27(3): 360-85.

- 2012b. "The euro and its guardian of stability: fiction and reality of the 10th anniversary blast." in L.-P. Rochone and Salewa 'Yinka Olawoye (eds.) Monetary Policy and Central Banking: New Directions in Post-Keynesian Theory. Cheltenham, U.K. and Northampton, MA: Edward Elgar. 
- 2013a. "At the crossroads: The euro and its central bank guardian (and savior?)." Cambridge Journal of Economics 37(3): 609-26.

- 2013b. "On the Franco-German euro contradiction and ultimate euro battleground." Contributions to Political Economy 32:127-49.

- 2013c. "Germany and the Euroland crisis: The making of a vulnerable haven." Levy Economics Institute Working Paper no. 767, June. http://www.levyinstitute.org/publications/?docid=1833

—. 2013d. "Lost at sea: The euro needs a Euro Treasury." IMK Study no. 35, November. http://www.boeckler.de/pdf/p_imk_study_35_2013

- 2015. "Much Excitement — and Lots of Confusion_About 'Helicopter Money' of Late.” Blog post, January. http://multiplier-effect.org/much-excitement-and-lots-of-confusionabout-helicopter-money-of-late/

Bibow, J., and A. Terzi (eds.). 2007. Euroland and the World Economy: Global Player or Global Drag? Basingstoke and New York: Palgrave Macmillan.

Bindseil, U., A. Manzanares, and B. Weller. 2004. "The role of central bank capital revisited." ECB, working paper no. 392, September. https://www.ecb.europa.eu/pub/pdf/scpwps/ecbwp392.pdf

Boland, V. 2015. “ECB's Irish aid totally unprecedented, says Jean-Claude Trichet.” Financial Times, April 30.

Bologna, P., and M. Caccavaio. 2014. "Euro area (cross-border?) banking.” Banca D'Italia, Questioni di Economia e Finanza Occasional Paper, no. 228, September.

Borio, C., M. Drehmann, and K. Tsatsaronis. 2013. "Stress-testing macro stress testing: Does it live up to expectations?” BIS Working Paper no. 369. http://www.bis.org/publ/work369.pdf.

Bowdler, C., and A. Radia. 2012. "Unconventional monetary policy: the assessment." Oxford Review of Economic Policy 28(4): 603-21.

Bryant, C. 2012. "Merkel supports Bundesbank chief.” Financial Times, August 26.

Buchheim, C. 1998. "Die Errichtung der Bank deutscher Länder und die Währungsreform in Westdeutschland." in Fünfzig Jahre Deutsche Mark: Notenbank und Währung in Deutschland seit 1948, Deutsche Bundesbank. München: C.H. Beck.

Buchheim, C. 2001. "Die Unabhängigkeit der Bundesbank—Folge eines amerikanischen Oktrois?" Vierteljahreshefte für Zeitgeschichte Band 49(1): 1-30.

Buiter, W.H. 2014. "The simple analytics of helicopter money: why it works - always." Economics, the Open-Access, Open-Assessment E-Journal, 8(2014-28):1-51. 
Buiter, W.H., and A. Sibert. 2006. "How the Eurosystem's open-market operations weaken financial market discipline (and what to do about it)." in Fiscal Policy and the Road to the Euro. Warsaw: National Bank of Poland.

Buiter, W.H., J. Michels, and E. Rahbari. 2011. "ELA Emperor without clothes.” Citi Global Economics View, January 21. https://ir.citi.com/t2v4rG\%2FgN0bwm\%2B8wmQ4MDeRzMwjHaHMX\%2BKeuHSvF $\mathrm{AEk} \% 3 \mathrm{D}$

Buiter, W., and E. Rahbari. 2012a. "Looking into the deep pockets of the ECB." Citi Global Economics View, February 27.

- 2012b. "The ECB as lender of last resort for sovereigns in the Eurozone." Journal of Common Market Studies 50: 6-35.

Butt, N., R. Churm, M. McMahon, A. Morotz, and J. Schanz. 2014. "QE and the bank lending channel in the UK." Bank of England Working Paper, no 511, September. http://www.bankofengland.co.uk/research/Pages/workingpapers/2014/wp511.aspx

Capie, F., C.A.E. Goodhart, and N. Schnadt. 1994. "The Development of Central Banking." in F. Capie, S. Fischer, C.A.E. Goodhart, and N. Schnadt (eds.), The Future of Central Banking: the Tercentenary Symposium of the Bank of England. Cambridge, U.K.: Cambridge University Press.

Cecchetti, S.G., R.N. McCauley, and P.M. McGuire. 2012. "Interpreting TARGET2 balances." BIS Working Papers, no. 393, December.

CESifo 2014. "Ifo President Sinn Welcomes Schäuble's Opposition to ECB Bond Purchases." May 22. http://www.cesifogroup.de/ifoHome/presse/Pressemitteilungen/PressemitteilungenArchiv/2014/Q2/press 20140522 anleihe.html

Chrysoloras, N., and G. Georgiou. 2014. "Cyprus Canvasses Draghi on Debt Swap to Ease Bank Burden.” Bloomberg, July 16.

Claeys, G. 2014. "The (not so) unconventional monetary policy of the European Central Bank since 2008.” European Parliament, IP/A/Econ/2014/02, June.

Claeys, G., Z. Darvas, S. Merler, and G. Wolff. 2014. "Addressing weak inflation. The European Central Bank’s shopping list.” Bruegel Policy Contribution 2014/05, May.

Constâncio, V. 2013. "The nature and significance of Banking Union." Speech, London, March 11, https://www.ecb.europa.eu/press/key/date/2013/html/sp130311.en.html

- 2014. "A new phase of the ECB's monetary policy." Speech, Frankfurt, October 6, http://www.ecb.europa.eu/press/key/date/2014/html/sp141006.en.html

Council of the European Union. 1993. "Council Regulation 3603/93 on monetary financing." http://eur-lex.europa.eu/legalcontent/EN/TXT/PDF/?uri=CELEX:31993R3603\&from=EN 
- 2005. "Memorandum of Understanding on co-operation between the bank supervisors, central banks and finance ministries of the European Union in financial crisis situations." http://www.eu2005.lu/en/actualites/documents_travail/2005/05/14ecofin_mou/

Darvas, Z., J. Pisani-Ferry, and G. Wolff. 2013. “Europe's growth problem (and what to do about it).” Bruegel, April 12. http://www.bruegel.org/publications/publicationdetail/publication/776-europes-growth-problem-and-what-to-do-about-it/

Darvas, Z., G. Claeys, S. Merler, and G.B. Wolff. 2014. “Addressing weak inflation: the ECB's shopping list." Bruegel, May 6.

De Grauwe, P. 2011. “The ECB as a lender of last resort.” VoxEU. http://www.voxeu.org/article/european-central-bank-lender-last-resort

—. 2013. "The ECB as lender of last resort in the government bond markets." CESifo Economic Studies 59(3): 520-35.

_. 2014. "Why the European Court of Justice should reject the German Constitutional Court's ruling on Outright Monetary Transactions." http://blogs.lse.ac.uk/europpblog/2014/03/04/why-the-european-court-of-justice-shouldreject-the-german-constitutional-courts-ruling-on-outright-monetary-transactions/

—. 2015. "Secular stagnation in the Eurozone." VoxEU, January 30.

De Santis, R.A. 2015. “A measure of redenomination risk.” European Central Bank Working Paper, no. 1785, April. https://www.ecb.europa.eu/pub/pdf/scpwps/ecbwp1785.en.pdf

Deutsche Bundesbank. 1994. The Monetary Policy of the Bundesbank. Frankfurt: Deutsche Bundesbank.

- 2012. "Statement to the Federal German Constitutional Court." in the Proceedings with Reference Nos. 2 BvR 1390/12, 2BvR 1421/12, 2 BvR 1439/12, 2 BvR 1824/12, 2 be 6/12, http://www.handelsblatt.com/downloads/8124832/1/stellungnahmebundesbank handelsblatt-online.pdf

- 2014. "Launch of the banking union: the Single Supervisory Mechanism in Europe." Monthly Report, October: 43-64.

Distel, J. 2003. Die Errichtung des westdeutschen Zentralbanksystems mit der Bank deutscher Länder. Tübingen: Mohr Siebeck.

Draghi, M. 2012. Verbatim of the remarks made by Mario Draghi. Speech, Global Investment Conference, London, July 26. http://www.ecb.europa.eu/press/key/date/2012/html/sp120726.en.html

- 2013. ECB press conference, April 4.

—. 2014a. "A consistent strategy for a sustained recovery." Lecture, Paris, March 25. https://www.ecb.europa.eu/press/key/date/2014/html/sp140325.en.html . 
- 2014b. "Unemployment in the euro area." Speech, Annual central bank symposium in Jackson Hole, WY, August 22.

http://www.ecb.europa.eu/press/key/date/2014/html/sp140822.en.html

—. 2015a. "Stability and prosperity in monetary union." op-ed, Project Syndicate, January

2. http://www.ecb.europa.eu/press/inter/date/2015/html/sp150102.en.html

—.2015b. ECB press conference, January 22.

_.2015c. "Letter to Mr. Matt Carthy." February 17.

-2015d. ECB press conference, March 5.

Dyson, K., and K. Featherstone. 1999. The Road to Maastricht: Negotiating Economic and Monetary Union. Oxford: OUP.

Economic Financial Committee (EFC). 2000. Report on Financial Stability.

_. 2011. Report on Financial Stability.

European Central Bank (ECB). various years. Annual Report.

—. various years. Financial Integration in Europe.

—. various years. Financial Stability Report.

. various years. Report on EU banking sector stability https://www.ecb.europa.eu/pub/pdf/other/eubankingsectorstability201009en.pdf

_. 1999. "TARGET and payments in euro." Monthly Bulletin, November.

_. 2003. "Memorandum of Understanding on high-level principles of co-operation between the banking supervisors and central banks of the European Union in crisis management situations." Press release, March 10.

http://www.ecb.europa.eu/press/pr/date/2003/html/pr030310_3.en.html

_. 2005a. "Asset price bubbles and monetary policy." Monthly Bulletin, April.

_.2005b. "Monetary policy and inflation differentials in a heterogeneous currency area." Monthly Bulletin, May.

_ 2006. "The EU arrangements for financial crisis management." Financial Stability Review, December.

—. 2006. "Report on Financial Supervision." October 26.

—. 2006. "The implementation of monetary policy in the euro area: General documentation on Eurosystem monetary policy instruments and procedures." September 2006.

_ 2007. "The EU arrangements for financial crisis management." Monthly Bulletin February. http://www.ecb.europa.eu/pub/pdf/mobu/mb200702en.pdf 
_.2008. "Financial stability and oversight." Monthly Bulletin, January.

—. 2009a. "Eurosystem monetary policy operations in 2008." Press release, March 5. http://www.ecb.europa.eu/press/pr/date/2009/html/pr090305_2.en.html

- 2009b. "The implementation of monetary policy since August 2007." Monthly Bulletin, July.

_ 2010. "The ECB's response to the financial crisis." Monthly Bulletin, October.

- 2012. Convergence Report. Frankfurt. May.

_ 2013a. "The Eurosystem Collateral Framework throughout the Crisis." Monthly Bulletin, July.

_.2013b. "ELA procedures." October 17. https://www.ecb.europa.eu/pub/pdf/other/elaprocedures.en.pdf?e0e0688fa82a174563d3c c838d7f5de 1

_ 2014a. "Recent developments in excess liquidity and money market rates." Monthly Bulletin, January.

— . 2014b. "Euro area risk-free interest rates: Measurement issues, recent developments and relevance to monetary policy." Monthly Bulletin, July.

—. 2014c. "Organisation of the SSM." Frankfurt.

—. 2014d. "Experience with foreign currency liquidity-providing central bank swaps." Monthly Bulletin, August.

European Commission. 1999. "Implementing the framework for financial markets: action plan." http://eur-lex.europa.eu/legalcontent/EN/TXT/HTML/?uri=URISERV:124210\&from=EN

_ 2009. "Report of the High-Level Group on Financial Supervision in the EU chaired by Jacques de Larosière." Brussels, February.

—. 2013. http://europa.eu/rapid/press-release_MEX-13-0716_en.htm?locale=en

—. 2014. “Annual Growth Survey 2015, COM (2014) 902 final.” November. http://ec.europa.eu/europe2020/pdf/2015/ags2015_en.pdf

—. 2015. "Building a capital markets union [by 2019]." Green Paper http://eurlex.europa.eu/legal-content/EN/TXT/PDF/?uri=COM:2015:63:FIN\&from=EN

European Council/Van Rompuy, H. 2012. "Towards a Genuine Economic and Monetary Union, Report by the President of the European Council, in collaboration with the Presidents of the Commission, the Eurogroup and the ECB." December 5.

http://www.consilium.europa.eu/uedocs/cms_Data/docs/pressdata/en/ec/134069.pdf 
European Court of Justice (ECJ). 2012. Judgment of November 27, 2012-Case C-370/12 PRINGLE.

http://curia.europa.eu/juris/celex.jsf?celex=62012CJ0370\&lang $1=$ en\&type=TXT\&ancre

—. 2015. “Opinion of Advocate General Cruz Villalón.” January 14.

http://curia.europa.eu/juris/celex.jsf?celex=62014CC0062\&lang1=en\&type=TXT\&ancre

European Investment Bank. 2015. "EIB Group proposes first operations for EFSI guarantee and rolls out the Investment Plan for Europe.” April 22.

European Monetary Institute. 1996. Progress towards Convergence 1996. Frankfurt. November.

Eucken, W. 1923. Kritische Betrachtungen zum deutschen Geldproblem.

. 1946. "Über die Verstaatlichung der Notenbank, unveröffentlichtes Gutachten.” Walter Eucken Archiv, Frankfurt a.M.

__. 2004 [1952]. “Grundsätze der Wirtschaftspolitik.” Mohr Siebeck, Tübingen, 7th ed.

Eurogroup. 2012. "Eurogroup Statement on Greece.” November 27. http://www.consilium.europa.eu/uedocs/cms_data/docs/pressdata/en/ecofin/133857.pdf

Fisahn, A. 2014. "Nur in guten Zeiten ... Grenzen der EZB in der Krise und die Grundlagen der EU." Gutachten im Auftrag der Rosa-Luxemburg-Stiftung, May.

Flassbeck, H. 2007. "Wage divergences in Euroland: Explosive in the making." in J. Bibow and A. Terzi (eds.) Euroland and the World Economy —Global Player or Global Drag? Basingstoke: Palgrave Macmillan.

Folkerts-Landau, D., and P.M. Garber. 1992. "The ECB: A bank or a monetary policy rule.” NBER Working Paper, no. 4016, March.

Friedman, M., and A. Schwartz. 1961. A Monetary History of the United States, 1867-1960. Princeton, NJ: Princeton University Press.

Friedman, M. 1963. “The role of monetary policy.” American Economic Review LVIII(1): 1-14. 1969. The optimum quantity of money. London: Macmillan.

_ 2002. "Comment on Gaspar and Issing." Australian Economic Papers 41(4): 366-68.

Freixas, X., C. Giannini, G. Hoggarth, and F. Soussa. 1999. "LOLR : A review of the literature." Financial Stability Review 7: 151-67.

Gagnon, J., M. Raskinb, J. Remacheb, and B. Sack. 2011. "The financial market effects of the Federal Reserve's large-scale asset purchases." International Journal of Central Banking 7(1): 3-43.

German (Federal) Constitutional Court. 2014a. January 14, [OMT]. http://www.bverfg.de/entscheidungen/rs20140114_2bvr272813.html 
. 2014b. March 18, [ESM]. https://www.bundesverfassungsgericht.de/entscheidungen/rs20140318_2bvr139012.html

Gilbert, M. 2015. "Bill Gross: Short of a Lifetime Would Mean Armageddon." Bloomberg, April 22.

Goodhart, C.A.E. 1988. The Evolution of Central Banks. Cambridge, MA: MIT Press. . 1992. "National fiscal policy within EMU: The fiscal implications of Maastricht." in C.A.E. Goodhart (ed.) EMU and ESCB after Maastricht. London: Financial Markets Group.

- 1997. "The two concepts of money, and the future of Europe." Available at SSRN: http://ssrn.com/abstract $=41726$ 1998. "The two concepts of money: implications for the analysis of optimal currency areas." European Journal of Political Economy 14: 407-32. . 1999. "Myths about the Lender of Last Resort." International Finance 2(3): 339-60. . (ed.) 2000. Which Lender of Last Resort for Europe? London: Central Banking Publication.

- 2005. "The links between fiscal and monetary policies on the one hand and financial stability on the other." paper presented at the Conference of the Austrian National Bank, Vienna, May.

—. 2007. "Replacing the Stability and Growth Pact?" in J. Bibow and A. Terzi (eds.) Euroland and the World Economy: Global Player or Global Drag? Basingstoke: Palgrave-Macmillan.

_. 2012. "Monetary policy and public debt." Banque de France Financial Stability Review 16(April): 123-30.

Goodhart, C.A.E., and J.P. Ashworth. 2012. "QE: a successful start may be running into diminishing returns." Oxford Review of Economic Policy 28(4): 640-70.

Goodhart, C.A.E., and G. Illing. 2002. Financial Crises, Contagion, and the Lender of Last Resort, A Reader. Oxford: Oxford University Press.

Goodhart, C.A.E., and D. Schoenmaker. 1995. "Should the Functions of Monetary Policy and Bank Supervision Be Separated?” Oxford Economic Papers 47(4): 539-60.

_. 2006. "Burden sharing in a banking crisis in Europe." LSE Financial Markets Group Special Paper, 164.

_. 2009. "Fiscal Burden Sharing in Cross-Border Banking Crises." International Journal of Central Banking March: 141-65. 
Greenwood, R., S.G. Hanson, J.S. Rudolph, and L.H. Summers. 2014. "Government debt management at the zero lower bound." Hutchins Center on Fiscal and Monetary Policy at Brookings Institution, Working Paper no. 5, September 30.

http://www.brookings.edu/research/papers/2014/09/30-government-debt-managementzero-lower-bound

Groen, W.P. de. 2014. "Was the ECB's Comprehensive Assessment up to standard?" CEPS Policy Brief, no. 325, November.

Grossekettler, H. 2003. "Walter Eucken.” Westfälische Wilhelms-Universität Münster, Volkswirtschaftliche Diskussionsbeiträge, no. 347, http://sgr.pte.pl/wpcontent/uploads/2015/02/Heinz-Grossekettler-Walter-Eucken.pdf

Gürkaynak, R. 2005. "Econometric tests of asset price bubbles: Taking stock." Finance and Economics Discussion Series no. 2005-04, Federal Reserve Board.

Hein, E., and A. Truger. 2007. "Fiscal policy and macroeconomic performance in the euro area: Lessons for the future." in J. Bibow and A. Terzi (eds.) Euroland and the World Economy: Global Player or Global Drag? Basingstoke: Palgrave-Macmillan,

Hellwig, M. 2014a. "Financial stability, monetary policy, banking supervision, and central banking." Max Planck Institute for Research on Collective Goods, Bonn, 2014/9.

—. 2014b. "Yes Virginia, there is a European Banking Union! But it may not make your wishes come true.” Max Planck Institute for Research on Collective Goods, Bonn, 2014/12.

Hennigan, M. 2014. “Germanys Schäuble opposes ECBs OMT bond-buying program.” May 23, Finfacts Ireland. http://www.finfacts.ie/irishfinancenews/article_1027709.shtml

Hentschel, V. 1988. "Die Entstehung des Bundesbankgesetzes 1949-1957. Politische Kontroversen und Konflikte, Teile 1 und 2." Bankhistorisches Archiv 3-31: 79-115.

Hetzel, R. 2013. "ECB Monetary Policy in the Recession: A New Keynesian (Old Monetarist) Critique.” Federal Reserve Bank of Richmond Working Paper 13-07, June.

Hölscher, J. 1994. Entwicklungsmodell Westdeutschland-Aspekte der Akkumulation in der Geldwirtschaft. Berlin: Duncker und Humbolt.

Holtfrerich, C.-L. 1988. "Relations between monetary authorities and governmental institutions: the case of Germany from the 19th century to the present." in G. Toniolo (ed.) Central Banks' Independence in Historical Perspective. Berlin and New York: Walter de Gruyter.

1999. "Monetary policy under fixed exchange rates (1948-1970)." in Deutsche Bundesbank (ed.), Fifty Years of the Deutsche Mark: Central Bank and the Currency in Germany since 1948. Oxford: Oxford University Press.

—. 2008. "Monetary policy in Germany since 1948: national tradition, international best practice or ideology?” in J.-P. Touffut (ed.) Central Banks as Economic Institutions. Cheltenham: Edward Elgar. 
Howarth, D., and L. Quaglia. 2013. "Banking on Stability: the political economy of new capital requirements in the European Union." Journal of European Integration 35(3): 333-46.

IMF. 2013. "A banking union for the euro area: staff discussion notes and technical background notes." February 13.

—. 2014a. "Euro area policies: 2014 Article IV consultation.” July. http://www.imf.org/external/pubs/ft/scr/2014/cr14198.pdf

- 2014b. "World Economic Outlook, chapter 3: Is it time for an infrastructure push? The macroeconomic effects of public investment." October.

Irwin, N. 2013. The Alchemists: Three Central Bankers and a World on Fire. New York: Penguin.

Issing, O. 2014. "Monetary policy and balance sheet adjustment." SAFE White Paper Series, no. 15.

James, H. 1998. "Die Reichsbank.” in Fünfzig Jahre Deutsche Mark: Notenbank und Währung in Deutschland seit 1948. Deutsche Bundesbank. München: C.H. Beck.

- 2012. Making the European Monetary Union. Cambridge and London: Harvard University Press.

Joice, M., D. Miles, A. Scott, and D. Vajanos. 2012. "Quantitative easing and unconventional monetary policy — an introduction.” Economic Journal 122(November): F271-88.

Jones, C. 2014. “Bundesbank hawk signals backing for QE.” Financial Times, March 25.

Juncker, J.-C. 2014. “A new start for Europe: My agenda for jobs, growth, fairness, and democratic change." Strasbourg, July 15. http://www.eesc.europa.eu/resources/docs/jean-claude-juncker---political-guidelines.pdf

Keynes, J.M. 1930. A Treatise on Money, Collected Writings of John Maynard Keynes, vols. 5 and 6. London: Macmillan.

- 1936. The General Theory of Employment, Interest and Money, Collected Writings of John Maynard Keynes, vol. 7. London: Macmillan.

Lannoo, K. 2002. "Supervising the European financial system.” Centre for European Policy Studies (CEPS) Policy Brief no. 23, May.

Lastra, R.M. 2003. "The governance structure for financial regulation and supervision in Europe." Columbia Journal of European Law 10: 49-68.

Lawton, C., T. Buell, and J. Marson. 2014. “ECB Threatens to Cut Off Cypriot Banks.” Wall Street Journal, March 21.

Legrain, P. 2014. Why our Economies and Politics are in a Mess-and How to Put Them Right, European Spring.

Lindner, F. 2013. “Banken treiben Eurokrise.” IMK Report 82. 
Lindner, F., N. Soemer, and T. Theobald. 2014. "Opportunities and risks of the European Banking Union.” IMK Policy Brief, May.

Maharaj, T., M. Pelata, H. Haworth, and C. Aranda-Hassel. 2012. "Wider ECB collateral and LTROs." Credit Suisse Fixed Income Research, February 23.

Marsh, D. 1993. The Most Powerful Bank: Inside Germany’s Bundesbank. New York: Penguin.

Marzinotto, B, A. Sapir, and G.B. Wolff. 2011. "What kind of fiscal union?" Bruegel Policy Brief 2011/06, November, http://www.bruegel.org/publications/publicationdetail/publication/646-what-kind-of-fiscal-union/

Mayer, F.C. 2014. "Rebels Without a Cause? A Critical Analysis of the German Constitutional Court's OMT Reference.” German L aw Journal 15(02): 111-46.

McCauley, R.N., and G. von Peter. 2009. "The U.S. Dollar Shortage in Global Banking.” Quarterly Review March. Basel, Switzerland: Bank for International Settlements.

McGuire, P., and G. von Peter. 2009. "The US Dollar Shortage in Global Banking and the International Policy Response.” Bank for International Settlement Working Paper No. 291, October.

Merler, S., and J. Pisani-Ferry. 2012. "Hazardous tango: sovereign-bank interdependence and financial stability in the euro area." Banque de France Financial Stability Review, no. 16, April.

Milligan, T. 2012. “Tracking the ELA.” Cumberland Advisors, September 6. http://www.cumber.com/commentary.aspx?file=090612.asp

Mody, A. 2009. "From Bear Stearns to Anglo Irish: How Eurozone Sovereign Spreads Related to Financial Sector Vulnerability." International Monetary Fund, Working Paper 09/108.

—. 2014. "Did the German court do Europe a favor?" Bruegel Working Paper 2014/09, July.

Möller, H. 1976. "Die westdeutsche Währungsreform von 1948." in Währung und Wirtschaft in Deutschland 1876-1975, Deutsche Bundesbank (Hrsg.). Frankfurt: Knapp Verlag.

Muellbauer, J. 2014. “Combatting Eurozone deflation QE for the people.” VoxEU, December 23.

Musgrave, R.A. 1939. "The nature of budgetary balance and the case for a capital-budget." American Economic Review 29: 260-71.

. 1959. The Theory of Public Finance. A Study in Public Economy. New York: McGrawHill.

Obstfeld, M. 2013. "Finance at center stage: some lessons of the euro crisis." European Economy Economic Papers 493, April.

OFCE/IMK/ECLM. 2014. “Independent Annual Growth Survey 2015, $3^{\text {rd }}$ Report.” December. http://www.iags-project.org/documents/iags report2015.pdf 
Orphanides, A. 2014a. "The euro area crisis: politics over economics." Atlantic Economic Journal 42(3): 243-63. http://link.springer.com/article/10.1007\%2Fs11293-014-9419-1

- (2014b). "Are rules and boundaries sufficient to limit harmful central bank discretion? Lessons from Europe.” IMFS Working Paper Series, no. 84, October. http://www.imfsfrankfurt.de/fileadmin/user upload/IMFS WP/IMFS WP 84.pdf.

Öztürk, B., and M. Mrkaic. 2014. "SMEs' access to finance in the euro area: what helps or hampers?" IMF Working Paper no. 14/78.

Padoa-Schioppa, T. 2000. "EMU and banking supervision." in C.A.E. Goodhart (ed.) Which Lender of Last Resort of Europe. London: Central Bank Publication.

—. 2004. The Euro and Its Central Bank: Getting United After the Union. Cambridge: MIT Press.

Panetta, F. 2009. "Financial sector rescue programmes.” BIS Paper, Bank for International Settlement, Basel.

Pâris, P., and C. Wyplosz. 2014. "PADRE Politically Acceptable Debt Restructuring in the Eurozone." CEPR, Geneva Reports on the World Economy Special Report no. 3, January. http://www.voxeu.org/sites/default/files/Geneva_Special_Report_3.pdf

Peersman, G. 2014. "The effectiveness of unconventional monetary policies." Gent University Working Paper no 875, February.

Persaud, A. 2000. "Sending the herd off the cliff edge: the disturbing interaction between herding and market-sensitive risk management practices." First Prize, Jacques de Larosiere Awards in Global Finance, reprinted in BIS Papers no. 2. http://www.bis.org/publ/bppdf/bispap021.pdf

—. 2014. "Why bail-in securities are fool's gold." Peterson Institute for International Economics Policy Brief PB 14-23, November.

Petrovic, A., and R. Tutsch. 2009. "National rescue measures in response to the current financial crisis." ECB Legal Working Paper no. 8, July, http://www.ecb.europa.eu/pub/pdf/scplps/ecblwp8.pdf.

Pianeselli, D., and A. Zaghini. 2014. "The cost of firms' debt financing and the global financial crisis.” Banca D'Italia Temi di discussione, no. 950, February.

Pignal, S. 2011. "Dexia brought to a halt." Financial Times, October 25.

Pisani-Ferry, J. 2014. The Euro Crisis and its Aftermath. Oxford: Oxford University Press.

Pisani-Ferry, J., and G.B. Wolff. 2012. "The fiscal implications of a banking union." Bruegel, Policy Brief no. 748. http://www.bruegel.org/publications/publicationdetail/publication/748-the-fiscal-implications-of-a-banking-union/

Pop, V. 2012. "Bundesbank skeptical on EU banking union.” EUObserver, December 17. https://euobserver.com/economic/118539. 
Praet, P. 2013. "The crisis response in the euro area.” European Central Bank, speech, Beijing, April 17. https://www.ecb.europa.eu/press/key/date/2013/html/sp130417.en.html.

Prati, A., and G.J. Schinasi. 1998. "Will the ECB be the LOLR in EMU." in M. Artis, A. Weber, and E. Hennessy (eds.) The Euro: A Challenge and Opportunity for Financial Markets. London: Routledge.

- 2000. "Financial stability in European EMU." in C.A.E. Goodhart (ed.) Which Lender of Last Resort for Europe? London: Central Banking Publications.

Randow, J. 2014. "Weidmann citing legitimacy of QE paves way for ECB consensus." Bloomberg, April 11. http://www.bloomberg.com/news/articles/2014-04-11/weidmannciting-qe-legitimacy-paves-way-for-consensus-ecb.

Reichlin, L. 2013. "Monetary policy and banks in the euro area: the tale of two crises." Bank of Greece, Special Conference Paper, July.

Reichlin, L., A. Turner, and M. Woodford. 2013. "Helicopter money as a policy option." VoxEU.org, May 20.

Rieter, H., and M. Schmolz. 1993. "The ideas of German Ordoliberlism 1938-45: pointing the way to a new economic order." European Journal of the History of Economic Thought 1(1): 87-114.

Rogers, J.H., C. Scotti, and J.H. Wright. 2014. "Evaluating asset-market effects of unconventional monetary policy: a cross-country comparison." Federal Reserve International Finance Discussion Paper no. 1101, March, http://www.federalreserve.gov/pubs/ifdp/2014/1101/ifdp1101.pdf

Schinasi, G.J., and P.G. Teixeira. 2006. "The lender of last resort in the European single financial market.” IMF Working Paper WP/06/127.

Schoenmaker, D. 1997. "Banking supervision and lender of last resort in EMU." in M. Andenas, L. Gormley, C. Hadjiemmanuil, and I. Harden (eds.) European Economic and Monetary Union: The Institutional Framework. London: Kluwer Law International.

- 2000. "What kind of financial stability for Europe?" in C.A.E. Goodhart (ed.) Which Lender of Last Resort for Europe? London: Central Banking Publication.

—. 2011. "The financial trilemma." Economic Letters 111: 57-9.

—. 2012. "Banking Union: where we're going wrong." in T. Beck (ed.) Banking Union for Europe: Risks and Challenges. London: CEPR.

. 2013. "Post-crisis reversal in banking and insurance integration: An empirical survey, European Economy.” Economic Paper no. 496. 
—. 2012. "Die Rolle der EZB in der Europäischen Staatsschuldenkrise.” Europäisches Wirtschafts- und Steuerrecht, 23, Heft 3/12: 80-90.

Siekmann, H., and V. Wieland. 2013.“ The ECB's outright monetary transactions and the Federal Constitutional Court of Germany.” SAFE, White Paper Series, No. 4.

Sinn, H.W. 2011a. “The ECB's secret bailout strategy.” Project Syndicate, April 29.

—. 2011b. “The ECB's stealth bailout." VoxEU.org, June 1.

—. 2012. "Fed versus ECB: How Target debts can be repaid.” VoxEU.org, March 10.

—. 2014. "Ifo President Sinn Welcomes Schäuble's Opposition to ECB Bond Purchases." http://www.cesifo-group.de/ifoHome/presse/Pressemitteilungen/PressemitteilungenArchiv/2014/Q2/press_20140522_anleihe.html

Sinn, H.W., and T. Wollmershuser. 2012. "TARGET loans, current account balances and capital flows: The ECB's rescue facility." NBER Working Paper no. 17626, November.

Soros, G. 2012. "The Tragedy of the EU and How to Resolve It." The New York Review of Books, September 27.

Spiegel, P. 2013. “Cyprus agrees deal on €10bn bailout.” Financial Times, March 25. http://www.ft.com/intl/cms/s/0/03c5e484-94ff-11e2-b82200144feabdc0.html\#axzz3cYxgUFn6.

Starbatty, J. 1994. “Ordoliberalismus.” in O. Issing (ed.) Geschichte der Nationalökonomie, 3. Aufl. München: Vahlen.

Steen, M. 2013a. "ECB role in bailout comes under scrutiny." Financial Times, March 18. http://www.ft.com/intl/cms/s/0/34045190-8ff9-11e2-923900144feabdc0.html\#axzz3cYxgUFn6.

—. 2013b. "ECB issues ultimatum to Cyprus." CNNFinancial Times, May 21. http://www.cnn.com/2013/03/21/business/ecb-cyprus-liquidity-crisis/index.html .

Steffen, S. 2014. "Robustness, validity, and significance of the ECB's asset quality review and stress test exercise.” European Parliament, October. http://www.europarl.europa.eu/RegData/etudes/STUD/2014/528761/IPOL_STU\%28201 4\%29528761_EN.pdf

Stern, K. 1998. “Die Notenbank im Staatsgefüge.” in Fünfzig Jahre Deutsche Mark: Notenbank und Währung in Deutschland seit 1948. Deutsche Bundesbank. München: C.H. Beck.

Tily, G. 2007. Keynes Betrayed: The General Theory, the Rate of Interest and "Keynesian" Economics. Basingstoke: Palgrave Macmillan. 
Tonveronachi, M. 2014. "The ECB and the Single European Financial Market: A proposal to repair half of the flawed design.” Levy Economics Institute Public Policy Brief, no. 137, September.

Trichet, J.-C. 2004. "Reforms good for growth with Europe on track for recovery: Interview with A. Krosta and A. Major." Financial Times, April 23.

- 2006. "EMU and the euro: successes and challenges." Speech, Zurich, March 30. http://www.ecb.europa.eu/press/key/date/2006/html/sp060330.en.html

- 2008. "Toward the first decade of EMU—experiences and perspectives." European Central Bank speech, Vienna, April 28. http://www.ecb.europa.eu/press/key/date/2008/html/sp080428.en.html .

_. 2009. "The financial crisis and the response of the ECB." European Central Bank speech, Sofia, June 12. http://www.ecb.europa.eu/press/key/date/2009/html/sp090612.en.html.

- 2010. "State of the Union: The Financial Crisis and the ECB's Response between 2007 and 2009." Journal of Common Market Studies 48: 7-19.

Tucker, P. 2014a. "Independent agencies in democracies: legitimacy and boundaries for the new central banks.” 2014 Gordon Lecture, Harvard Kennedy School.

- 2014b. "The lender of last resort and modern central banking: principles and reconstruction.” BIS Papers no. 79, September.

Ubide, A. 2013. "How to form a more perfect European banking union.” Peterson Institute for International Economics Policy Brief 13-23, October.

—. 2014. "Is the European Central Bank failing its price stability mandate?" Peterson Institute for International Economics Policy Brief no. PB 14-5, February.

Valiante, D. 2014. "Framing banking union in the euro area: some empirical evidence." CEPS no. 389 , February.

Veron, N. 2007. “Is Europe ready for a major banking crisis?” Bruegel, Policy Brief.

- 2014. "Overhaul of EU financial system needed to foster growth." in Rebuilding Europe's common future: Combining growth and reform in the euro area, PIIE Briefing 14-5, December.

—. 2015. "Europe’s radical banking union.” Bruegel Essay and Lecture Series.

Veron, N., and G.B. Wolff. 2015. "Capital markets union: a vision for the long term.” Bruegel Policy Contribution 2015/05. Brussels, April 24.

Weale, M., and T. Wieladek. 2014. "What are the macroeconomic effects of asset purchases?" External MPC Unit Discussion Paper no. 42, Bank of England, April.

Weber, A.A. 2008. "Financial market stability.” Speech, London, June 6. 
Weidmann, J. 2013a. "Eingangserklärung anlässlich der mündlichen Verhandlung im Hauptsacheverfahren ESM/EZB, June 11. https://www.bundesbank.de/Redaktion/DE/Kurzmeldungen/Stellungnahmen/2013 $06 \quad 1$ 1 esm ezb.html

2013b. "Who calls the shots? The problem of fiscal dominance." Speech, Paris, May 24. http://www.bis.org/review/r130524d.pdf

- 2015. "Heading for stability and prosperity_-bringing the euro area back on track." Speech, London, February 12.

Whelan, K. 2012a. "ELA, promissory notes and all that: the fiscal costs of Anglo Irish Bank." University College Dublin Centre for Economic Research Working Paper 12/06, February. http://www.ucd.ie/t4cms/WP12_06.pdf

- 2012b. "TARGET 2 and central bank balance sheets." University College Dublin Center for Economic Research Working Paper 12/29 (revised March 2013).

—. 2013a. "Ireland's promissory note deal." Forbes, February 11.

- 2013b. "Sovereign default and the euro." UCD Centre for Economic Research Working Paper Series, WP13/09, July.

Winkler, A. 2014a. "The ECB as lender of last resort: banks versus governments.” LSE Financial Markets Group Special Paper no. 228, February.

- 2014b. "Rescues violating the German constitution: The Federal Court decides on a theory of finance." LSE Financial Markets Group Special Paper no 231.

Wolf, M. 2014. The Shifts and the Shocks: What We've Learned-and Have Still to Learnfrom the Financial Crisis. New York: Penguin Press.

Wolff, G.B. 2014. "Eurosystem collateral policy and framework: was it unduly changed?" Bruegel Policy Contribution, 2014/14, November. http://www.bruegel.org/publications/publication-detail/publication/857-eurosystemcollateral-policy-and-framework-was-it-unduly-changed/

Woodford, M. 2012. "Methods of Policy Accommodation at the Interest-Rate Lower Bound." Speech at Jackson Hole Symposium, August 20.

Wray, L.R. 2012. Modern Money Theory: A Primer for Macroeconomics of Sovereign Monetary Systems. Basingstoke: Palgrave Macmillan.

Zettelmeyer, J., C. Trebesch, and M. Gulati. 2012. "The Greek debt exchange: an autopsy." Economic Policy Panel Meeting, Dublin, April. http://www.economic-policy.org/wpcontent/uploads/2013/04/zettelmeyer.pdf 